\title{
Factors affecting enrolment of PLHIV into ART services in India
}

\author{
Avina Sarna \\ Population Council \\ Damodar Bachani \\ Mary Philip Sebastian \\ Population Council \\ Ruchi Sogarwal \\ Madhusudana Battala \\ Population Council
}

Follow this and additional works at: https://knowledgecommons.popcouncil.org/departments_sbsr-hiv

Part of the Demography, Population, and Ecology Commons, Family, Life Course, and Society Commons, Immune System Diseases Commons, International Public Health Commons, and the Medicine and Health Commons

How does access to this work benefit you? Let us know!

\section{Recommended Citation}

Sarna, Avina, Damodar Bachani, Mary Philip Sebastian, Ruchi Sogarwal, and Madhusudana Battala. 2010. "Factors affecting enrolment of PLHIV into ART services in India." New Delhi: Population Council. 


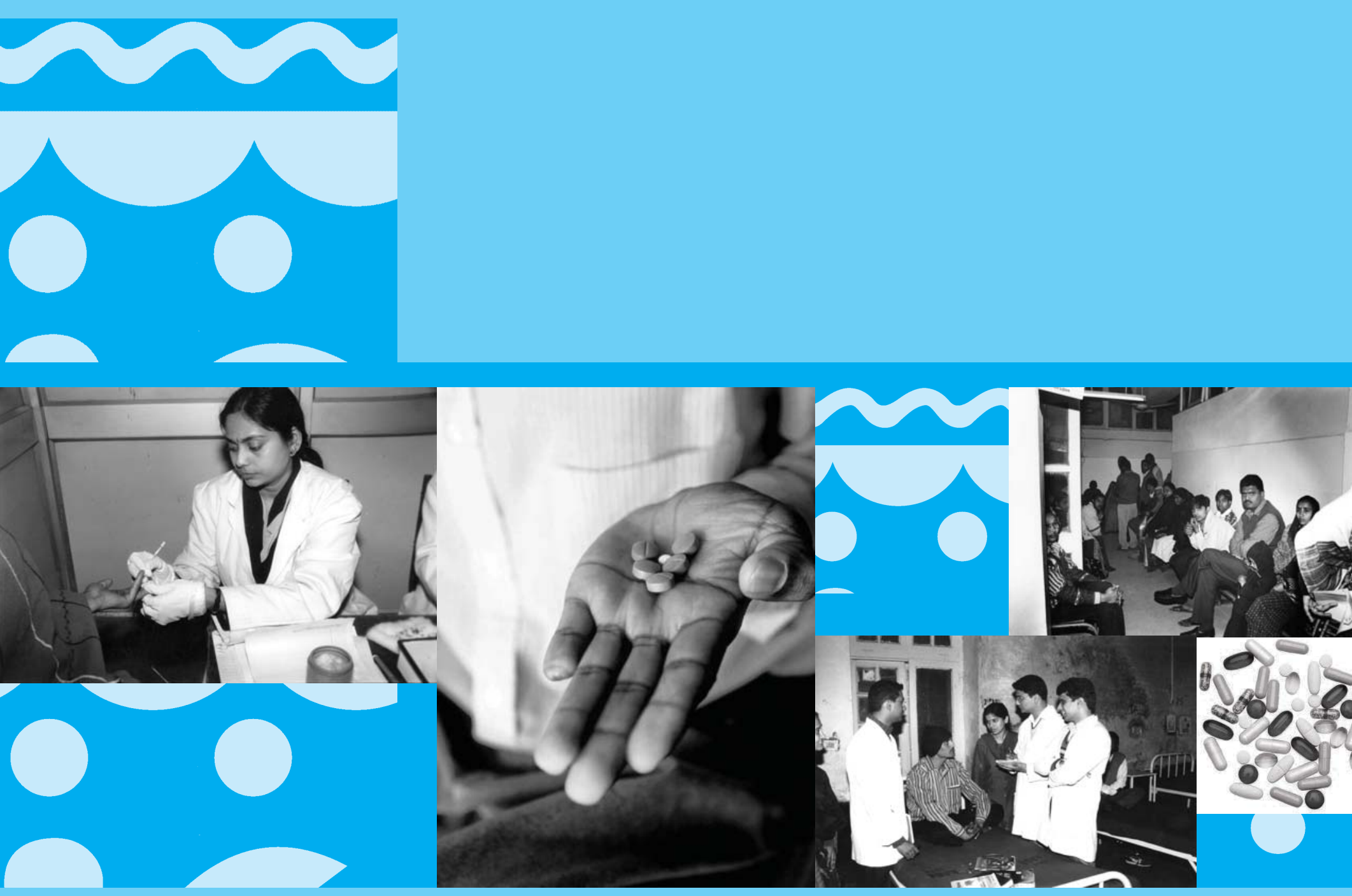

\section{Factors Affecting Enrolment of PLHIV into ART Services in India}

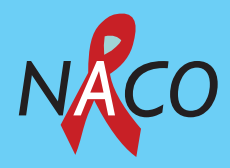


This report is a result of a collaborative study between National AIDS Control Organisation and the Population Council. Financial support for this study was provided by National AIDS Control Organisation, Ministry of Health and Family Welfare, Government of India.

\section{For additional copies of this report, please contact:}

\section{Population Council \\ 142 Golf Links \\ New Delhi 110003 \\ Phone: 011-24651314/41743410 \\ Email: jshiju@popcouncil.org \\ Website: http://www.popcouncil.org/asia/india.html}

\section{(P Population Council}

The Population Council conducts research worldwide to improve policies, programs, and products in three areas: HIV and AIDS; poverty, gender, and youth; and reproductive health.

Copyright @ 2010. The Population Council Inc.

Suggested citation: Sarna, Avina, Damodar Bachani, Mary Sebastian, Ruchi Sogarwal and Madhusudana Battala. 2010. 'Factors Affecting Enrolment of PLHIV into ART Services in India'. Delhi, India: Population Council.

For further details, please contact Dr Avina Sarna at asarna@popcouncil.org

This document may be reproduced in whole or in part without permission of the Population Council provided full source citation is given and the reproduction is not for commercial purposes. 

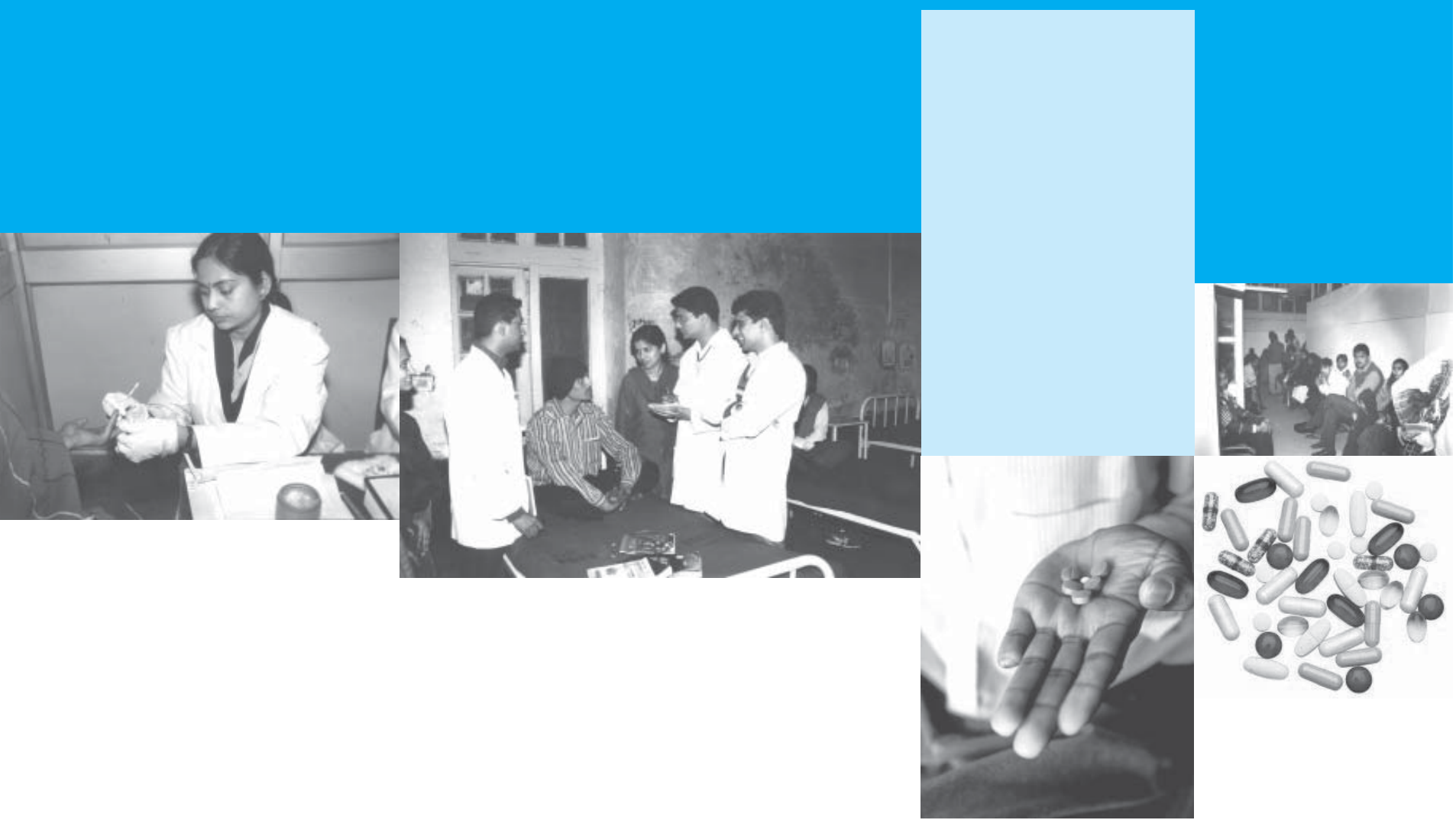

\title{
Factors Affecting Enrolment of PLHIV into ART Services in India
}

\author{
Avina Sarna \\ Mary Sebastian \\ Madhusudhana Battala \\ Population Council \\ Damodar Bachani \\ Ruchi Sogarwal \\ National AIDS Control Organisation
}

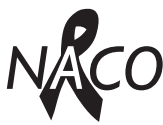

National AIDS Control Organisation Ministry of Health and Family Welfare Government of India 


\section{Acknowledgments}

The authors would like to thank our partner National AIDS Control Organisation (NACO) for their support in

the conduct of the study. A special thanks to Dr K. Chandramouly, Secretary, Department of AIDS Control and Director General, NACO for his support.

We would like to extend our thanks to all the medical officers in charge of ART and ICTC and nodal officers and other officials from the district: Dr Sharad Pore, SMO, Satara; Dr Sudhir Bakshi, Nodal Officer, Satara; Dr Pooja Ghorpade, SMO, Kolhapur: BCK Naik, Nodal Officer, Rajamundhry; Dr N. Suneetha, SMO, Rajahmundry, Dr K. Sathyanarayana Rao, Nodal Officer, Vijayawada; Dr Sudhakar, SMO, Vijayawada; Mr Timothy Nair, DPM, Vijayawada, Dr Pavan Kumar, ADDMHO, East Godavari, Dr Harevanshi, DAPCO, Bagalkot, Dr Koraddi, NO, Bagalkot; Dr Boke, SMO, Bagalkot; Dr Surekha N. Hadagali, DAPCO, Bijapur, Dr Sanjeev N. Bentur, SMO, Bijapur; Dr Anupam Shah, SMO, Jaipur; Dr Pradeep Gupta, PMO, Alwar; Dr B. Bhargav, CMS, Azamgarh; Dr Ashok Kumar, CMS, Bhadohi; Dr Mallik, ICTC in charge, Jaunpur; Dr Aviral Saxena, UPSACS; Dr Shyam Sunder, NO, Varanasi; Dr Deepti, SMO, Varanasi; Dr Jyoti, Center of Excellence, Varanasi; Dr Bhakti Bai Prajapati, Superintendent, Kadi, Gujarat; Dr J.G. Parmar, NO, Mehsana; DrGirish Bhai, SMO, Mehsana; Dr Dinesh Vyas, ICTC in-charge, Mehsana; Dr Dipak Bhai, ICTC in-charge, Patan; Dr Hemaben Patel, ICTC in charge, Palanpur; Dr (Prof.) M. Kulachandra Singh, NO, RIMS, Imphal; Dr N.S. Brajachand, Head, Microbiology Dept., RIMS, Imphal.

Our special thanks to Dr Niranjan Saggurti, Population Council, for his insightful comments and review of the report. This study could not have been done without the members of our research team: Research investigators Akhilesh Tripathi, Bidyanand Singh, Deepak Kumar, Jose Joseph, Pankaj S. Bhuyar, Pilli Jacob Sunil, Rakesh Kumar, Rana Jigar C., Sangamesh N. Keralli, Shrikant S. Ravaloji, Sonu K. Patil, and Teki Suresh and also the field investigators at ICTC Ameena Sahib, Amit Kumar Tripathi, Bharat Amrutlal Chorrasiya, Bharti Rambhau Jambhulkar, Chaudhry Nehaben Dalasangbhai, D. Devi, Dilshad Begum, S. Jamadar, Dinesh Somaji Uke, Erriyamma, Jayashri S.Hosamani, Jyothsna Chandrakanth, Malathi Latha Suvarnakanti, Manoj Kumar Sangela, Naresh Wamanrao Tajne, Pradnya Hambirrao Pawar, Prashant Kumar, Rajesh Kumar J. Prajapati, Ramesh S. Bhovi, Ranjit Kumar Vara, Rekha Soni, Rupali R. Malokar, Sangeeta Singh, Sarika S. Dhawade, Shiv Datt Kushwah, Sudha B. Konnur, Sumitra, Sushma Talluri, T. Jayamani and Vishal Dnyandeo Nanaware -- our deepest thanks to them. We would like to acknowledge Mr V.L. Thomas for administrative support. And lastly we would like to thank the study participants for their time and support.

This study was conducted with financial support from the National AIDS Control Organisation, Ministry of Health and Family Welfare, Government of India.

Published in October 2010. 


\section{Contents}

Acknowledgments $\quad$ ii

Abbreviations and Acronyms $\quad$ v

Abbriations

Executive Summary vi

$\begin{array}{lll}1.0 & \text { Introduction } & 1\end{array}$

2.0 The Project 3

2.1 Objectives 3

2.2 Selection of study districts and study sites 3

2.3 Ethical approval 4

$\begin{array}{ll}\text { 3.0 Secondary Data from ICTC and ART centers } & 6\end{array}$

$\begin{array}{lll}3.1 \text { Methods } & 6\end{array}$

3.2 Limitations and challenges 6

4.0 Integrated Counselling and Testing Centers $\quad 7$

$\begin{array}{lll}4.1 \text { Gender } & 8\end{array}$

$\begin{array}{ll}4.2 \text { Marital status } & 9\end{array}$

4.3 Education Level 9

$\begin{array}{lr}4.4 \text { Occupational status } & 10\end{array}$

$\begin{array}{lll}4.5 & \text { Route of Infection } & 11\end{array}$

$\begin{array}{lll}5.0 & \text { ART Centers } & 12\end{array}$

$\begin{array}{ll}5.1 \text { Gender } & 12\end{array}$

$\begin{array}{ll}5.2 \text { Marital status } & 13\end{array}$

$\begin{array}{llr}5.3 & \text { Education Level } & 14\end{array}$

$\begin{array}{llr}5.4 & \text { Employment status } & 14\end{array}$

5.5 Immune status: CD4 cell counts $\quad 15$

$\begin{array}{lll}5.6 & \text { Registration at ART centers } & 15\end{array}$

5.7 Comparison of clients from ICTCs and ART centers 16

$\begin{array}{lll}6.0 \text { Conclusions (secondary data analysis) } & 18\end{array}$

\begin{tabular}{ll}
7.0 Cohort study & 20 \\
\hline
\end{tabular}

$\begin{array}{ll}7.1 \text { Methods } & 20\end{array}$

$\begin{array}{ll}7.2 \text { Study design } & 20\end{array}$ 
$\begin{array}{ll}7.3 \text { Study sites } & 20\end{array}$

$\begin{array}{ll}7.4 \text { Study population and recruitment } & 20\end{array}$

$\begin{array}{ll}7.5 \text { Data collection and management } & 21\end{array}$

$\begin{array}{ll}\text { 7.6 Limitations and challenges } & 21\end{array}$

$\begin{array}{llr}8.0 & \text { Results } & 22\end{array}$

$\begin{array}{lll}8.1 & \text { Recruitment and retention of cohort } & 22\end{array}$

$\begin{array}{ll}8.2 \text { Profile of study participants } & 23\end{array}$

8.2.1 Socio demographic profile of study participants 23

8.2.2 Employment and income 25

$\begin{array}{ll}8.2 .3 \text { Poverty } & 26\end{array}$

$\begin{array}{ll}8.3 \text { HIV testing } & 27\end{array}$

$\begin{array}{ll}\text { 8.3.1 Referrals } & 27\end{array}$

$\begin{array}{ll}\text { 8.3.2 Reasons for undertaking HIV test } & 27\end{array}$

$\begin{array}{ll}\text { 8.3.3 HIV testing and counselling services } & 29\end{array}$

$\begin{array}{lll}8.4 & \text { Disclosure of HIV status } & 34\end{array}$

8.5 HIV Positive participants interviewed at ART centers 38

$\begin{array}{lll}\text { 8.5.1 Time taken to reach ART center } & 38\end{array}$

8.5.2 Health care services accessed $\quad 39$

$\begin{array}{ll}\text { 8.5.3 Access to ART centers } & 41\end{array}$

8.5.4 Quality of services at ART centers 45

8.6 Clients interviewed in the community (did not register at ART Centers) 50

$\begin{array}{ll}\text { 8.6.1 Health care services accessed } & 50\end{array}$

$\begin{array}{ll}\text { 8.6.2 Registration at other ART centers } & 51\end{array}$

$\begin{array}{ll}\text { 8.6.3 Reasons for not registering at ART } & 51\end{array}$

8.6.4 Awareness about the availability of free ART and CD4 Test 54

$\begin{array}{lll}8.7 & \text { Registration at ART centers } & 55\end{array}$

$\begin{array}{ll}9.0 \text { Conclusions } & 58\end{array}$

References

$\begin{array}{ll}\text { Annex } 1 \text { Quick Poverty Score for India } & 63\end{array}$

Annex 2 Informed consent form - Baseline 64

Annex 3 Baseline Survey Questionnaire $\quad 66$

Annex 4 Informed consent form - Endline $\quad 79$

$\begin{array}{ll}\text { Annex } 5 \text { Endline Survey Questionnaire } & 81\end{array}$ 


\section{Abbreviations and Acronyms}

\begin{tabular}{|c|c|}
\hline AIDS & Acquired Immune Deficiency Syndrome \\
\hline ANC & Ante-Natal Check-up \\
\hline ANM & Auxillary Nurse and Midwife \\
\hline ART & Antiretroviral therapy \\
\hline ARTC & Anti Retroviral Treatment Center \\
\hline ARV & Anti Retroviral \\
\hline ASHA & Accredited Social Health Activist \\
\hline BPL & Below Poverty Line \\
\hline $\mathrm{CBC}$ & Complete Blood Count \\
\hline $\mathrm{CBO}$ & Community-Based Organization \\
\hline $\mathrm{CCC}$ & Community Care Centers \\
\hline CD4 & T lymphocyte with CD4 receptor \\
\hline $\mathrm{CHC}$ & Community Health Center \\
\hline CLHIV & Children Living with HIV \\
\hline ELISA & Enzyme Linked Immuno Sorbent Assay \\
\hline HIV & Human Immunodeficiency Virus \\
\hline ICTC & Integrated Counselling and Testing Centers \\
\hline IDU & Injecting Drug User \\
\hline IQR & Inter Quartile Range \\
\hline MOHFW & Ministry of Health and Family Welfare \\
\hline NACO & National AIDS Control Organisation \\
\hline NGO & Non Governmental Organization \\
\hline PHC & Primary Health Center \\
\hline PLHIV & People Living with HIV \\
\hline PLHA & People Living with HIV and AIDS \\
\hline QPS & Quick Poverty Score \\
\hline RMP & Registered Medical Practitioner \\
\hline STI & Sexually Transmitted Infection \\
\hline TB & Tuberculosis \\
\hline
\end{tabular}




\section{Executive Summary}

India had an estimated 2.31 million (1.8 - 2.9) people living with HIV at the end of 2007, with a HIV prevalence of 0.34 per cent (NACO Annual Report, 2008-09). Despite the low HIV prevalence, these statistics place India among countries with a large number of people living with HIV (PLHIV). To address the care and support needs of PLHIV, the Ministry of Health and Family Welfare (MOHFW), Government of India, initiated a national programme in 2004 to provide free ART for PLHIV. At the end of March 2009, there were 211 functioning ARTCs and 254 CCCs across the country, and to date 2, 17,781 are receiving ART. A major challenge for the health system with its network of ART centers has been to increase utilization of ART services and enrolment into the program. It is important to understand the factors that contribute to utilization of ART services by HIV infected individuals.

The Population Council, with support from NACO, undertook a multi-site study in four high HIV prevalence and three low HIV prevalence states to understand the context and factors that influence the uptake of ART services.

\section{Methods}

The study was conducted in two phases. In Phase 1 we undertook analysis of secondary data collected from 30 ICTCs and 10 corresponding ART centers from ten districts across seven states. A cross sectional study design was used. The objective of the study was to understand and compare the socio-demographic characteristics of HIV positive people who were diagnosed HIV positive at ICTCs and those who registered for treatment at ART centers. This information was used to inform Phase 2. A total of 7814 people tested positive across the 30 participating ICTCs and 11568 HIV positive people registered for treatment at the 10 participating ART centers between October 1, 2008 and March 31, 2009.

In Phase 2, we conducted a prospective observational cohort study among newly diagnosed HIV-positive people tested at ICTCs. Individuals who tested positive at selected ICTCs were recruited into the study and followed till their registration at the referral ART center. Those who did not register at the referral ART center were tracked in the community for a follow-up interview. A total of 1057 newly diagnosed HIV positive people were recruited into the cohort from 27 ICTCs and followed prospectively for 2 months.

\section{Key Findings}

\section{Phase 1: Secondary Data}

There were more male clients than female clients at ICTCs (m: 56\% vs. f: 44\%) and ART centers (m: $51 \%$ vs. f: 49\%); the low prevalence states had substantially fewer women. The median age for participants was 35 years (IQR: 30, 40). 
The majority of clients at ICTCs and ART centers were married (ICTC: 78\%; ARTC: 70\%). The proportion of widowed clients was higher at ART centers (ARTC: 21\% vs. ICTC: 14\%). Women were more likely to be widowed at both ICTC and ART centers $(\mathrm{p}<0.001)$. The trend was similar across states.

There were more illiterate people at ART centers (ARTC: 50\% vs. ICTC: 42\%); and fewer people with primary education (ARTC: 22\% vs. ICTC: 28\%). Secondary education (ARTC: 22\% vs. ICTC: 23\%) and higher education levels differed to a lesser degree (ARTC: 6\% vs. ICTC: 7\%). Substantial differences were observed across states.

At ICTCs, more than half (51.5\%) of the participants were working as daily wage, unskilled manual labourers. At present, ICTCs do not collect information on unemployment as separate data, thus this information was not available. At ART centers, 81.2 per cent of clients were unemployed.

At ART centers, 63.4 per cent of newly diagnosed HIV positive people registered for treatment within one month (30 days) and 11.4 per cent registered within three months (31-90 days). However, 25.1 per cent registered after three months including 12.4 per cent who took more than a year to reach ART centers.

Analysis comparing data from ICTCs and ART centers, using a cut off of two months (60 days) to register at ART centers, shows that younger clients (<30 years: $68.7 \%$ vs. $31-45$ years: $72.7 \%$ vs. $>46$ years: $76 \%$; $\mathrm{p}<0.001$ ) and female clients (female: $68.5 \%$ vs. male: $74.4 \%$; $<0.001$ ) were significantly less likely to register within two months. Further, widowed and separated clients (widowed: 61.6\% vs. separated: 55.8\% vs. married: 70.5\% vs. single: 73.4\%; $\mathrm{p}<0.001$ ); and unemployed clients (unemployed: 69.7\% vs. employed: 76\%; $<<0.001$ ) were also less likely to register within two months.

\section{Phase 2: Prospective cohort study}

A total of 1057 newly diagnosed HIV positive participants were followed over two months.

Almost three-quarters $(73.5 \% ; \mathrm{n}=777)$ of the participants in the cohort registered at ART centers within two months and were interviewed at their respective ART centers. Of the remainder who did not register at ART centers within the reference period, 17.9 per cent $(n=189)$ were traced and interviewed in the community, 5.6 per cent $(n=60)$ were traced but not interviewed for various reasons (death: 32, migrated out: 14, refusals: 5 , not available for interview: 8 , registered elsewhere: 1$)$ and $2.9 \%(n=31)$ were untraced and lost to follow-up.

\section{Characteristics of the population}

Overall 51.7 per cent of the participants were male. The mean age was 34.7 years (SD 8.9). The majority were married (65\%) while 21.7 per cent were widowed. Female participants were more likely to be widowed (f: $34.8 \%$ vs. $7.6 \%$; $<0.001)$. Over half $(56.2 \%)$ of participants were illiterate and 78.8 per cent were employed, mostly as agricultural labour (68\%). The Quick Poverty Score card, India was used to assess poverty among study participants. Overall 38 per cent of the participants fell into categories with a higher probability of falling Below Poverty Line per national criteria. 


\section{HIV testing and counselling services}

The majority of study participants were referred for HIV testing from public sector health facilities (40.9\%).

Other referral categories included self referrals (18.8\%), referrals from private health facilities $(16.9 \%)$, from

NGOs $(11.9 \%)$ and friends and relatives (11.5\%).

Nearly a third of the participants (32.2\%) reported multiple HIV tests. Among those with multiple tests, 75.8

per cent had their first HIV test in the private sector. The majority $(92.6 \%)$ of study participants collected their HIV test result within one week (7days).

Overall 92 per cent of participants made a single visit to the ICTC for their HIV test; however, more than a tenth $(13.2 \%)$ of the participants had to make multiple visits to collect their HIV test results.

ICTC counsellors spent a median of 10 minutes (IQR: 5, 15) on pre-test counselling and a median of 20 minutes (IQR: 15, 30) on post-test counselling. The majority of participants $(86 \%)$, reported high levels of satisfaction with counsellors at ICTCs. However, some inadequacies in counselling procedures and content were documented. Overall, 30 per cent of clients were not told about how the HIV test works, 28 per cent of participants were not told about partner testing, 47 per cent did not receive instructions on condom use (demonstration), 21 per cent were not told about the CD4 test required for assessing eligibility for ART, and 13 per cent were not given a referral slip for the ART center. Importantly, 32 per cent of participants were not told that proof of identity and address is essential for registration at the ART center; it is important to provide clients with this information so as to avoid multiple visits to complete the registration process. Disclosure of HIV status to a partner/spouse or family members was not discussed with more than a quarter of the participants $(26 \%)$.

\section{Disclosure of HIV status}

Overall 69.3 per cent of participants had disclosed their HIV status to someone; disclosure was less frequent in the low prevalence states. Less than two-thirds (65.5\%) of participants disclosed their HIV positive status to sexual partners. Disclosure of status was significantly lower among participants interviewed in the community compared to those interviewed at ART centers $(54.8 \%$ vs. $72.9 \%$; $\mathrm{p}<0.001)$.

Fifty-eight per cent of those who had disclosed their HIV status to someone regretted their decision to disclose. Nearly a fifth (18\%) of all participants reported that they had been discriminated by friends and 8.5 per cent by their extended family.

A third of all participants knew one or more households in the community with a HIV positive family member.

\section{Clients who registered at ART centers within two months}

In all 777 (73.5\%) participants registered for treatment within two months and were interviewed at the ART center. Participants reached ART centers after a median of 7 days (IQR: 3, 18); 59.8 per cent participants regis- 
tered within a week and a further 30 per cent within one month. Most participants were accompanied by family members (66.3\%). Only 7.3 per cent had been assisted by a PLHA network member or out-reach worker $(3.9 \%)$.

\section{Health care services accessed}

About 4 per cent $(n=31)$ of these participants had used ARV medications in the past, prior to registering at the ART center. Thirty-four (4.4\%) participants were concurrently registered at other centers for treatment; most of them $(27 / 34)$ at other government ART centers.

A small proportion $(3 \% ; n=25)$ had consulted private allopathic physicians after their HIV test. Less than one per cent $(\mathrm{n}=7)$ of participants had consulted a traditional health practitioner; although 11 participants reported that they were taking traditional medications.

\section{Immune status at registration for treatment}

The majority (96.4\%) of participants had undertaken CD4 count test at the ART center. Overall 55 per cent of participants had CD 4 cell counts less than 250 cells $/ \mathrm{ml}$ making them eligible to start ART immediately. A higher proportion of participants in low prevalence states had CD4 cell counts less than 250 cells $/ \mathrm{ml}$.

\section{Problems faced in reaching ART centers}

Participants were asked about difficulties that they may have faced in reaching ART centers; open ended qualitative responses were recorded. Three-fourth (75.5\%) of participant faced no problems in reaching ART centers.

For the remainder the most frequently cited problem were transportation difficulties and distance to ART centers (11.3\%); financial difficulties and loss of wages at each visit to the ART center (5.7\%); ill health and associated difficulty in travelling distances (5.3\%); locating the ART center within the hospital (3\%) and multiple visits required due to strike by health workers $(1 \%)$.

\section{Quality of services at ART centers}

Forty per cent of participants had to visit the ART center two or more times to complete the registration process; this includes 10.8 per cent participants who made four or more visits.

Overall, waiting time to meet health providers was short; around two-third of the participants met counsellors and doctors within 30 minutes. At the registration visit, ART Counsellors spent less than 20 minutes with the majority $(90 \%)$ of participants. Doctors spent less than 10 minutes with the majority (85\%) of participants.

The majority of participants found ART counsellors sympathetic (84.4\%) and the counselling session private $(74.3 \%)$. Satisfaction levels were high; 94 per cent of participants were fully or somewhat satisfied with their interaction with the counsellor. Some inadequacies in counselling content were observed. Thirty per cent of participants were not informed about HIV testing for spouses/partners and children; CD4 tests to assess eligibility for ART was not discussed with 46 per cent of participants; and the need for regular follow-up for ART was 
not mentioned to a third of the participants. Linking clients with PLHA network members for support (and as an important tool for follow-up in the community) was done for less than a quarter (24\%) of the participants. Almost a third of the participants felt counsellors did not encourage asking of questions (30\%).

Most participants found doctors sympathetic (74\%) and 88 per cent of the clients were satisfied with their interaction with the physician. However, doctors appeared not to focus on the prevention of HIV transmission: 30 per cent of participants were not told about prevention of transmission of HIV; the importance of condom use was not mentioned to 60 per cent of participants and HIV testing for partners/spouse and children not discussed with 46 per cent of participants. With regard to ART, treatment adherence was not discussed with 53 per cent of participants and CD4 tests not discussed with half the participants. Around 41 per cent of participants felt that doctors did not encourage questions.

\section{Clients interviewed in the community (did not register at ART centers)}

A total of 189 participants, who did not register at ART centers, were interviewed in the community. Researchers tracked them with help from ICTC counsellors, out-reach workers and PLHA networks linked to the ICTC.

\section{Health care services accessed}

A small minority $(4.9 \%, \mathrm{n}=9)$ of participants had undertaken additional HIV tests to confirm their HIV diagnosis. Less than a tenth (9.6\%) had undertaken a CD4 test to assess eligibility for ART.

A very small number of participants $(n=25)$ ) had consulted a physician after their HIV test; most of them visited other government hospitals (13/25), while a few consulted private allopathic physicians $(6 / 25)$ and traditional healers $(6 / 25)$.

About a tenth $(9.6 \%, \mathrm{n}=18)$ of the participants had registered for ART at other health facilities; more than half $(8 / 18)$ registered at government ART centers in other districts for a variety of reasons including stigma, distance to ART center, transport concerns and financial difficulties.

\section{Reasons for not registering at ART centers}

The most frequently cited reason for not registering for treatment was being in good health and feeling well $(29.8 \%)$. Other reasons included being busy with work or family engagements $(22.2 \%)$, coming to terms with their diagnosis and fear of inadvertent disclosure of their status (8.8\%), financial difficulties (8.8\%), opposition by family members (5.3\%), and distance to ART center linked to ill health and travel problems (4.7\%). Other less frequent reasons were: not having someone to accompany them to the ART center $(3.5 \%)$, the need to confirm their HIV diagnosis with another HIV test (3.5\%), waiting to complete treatment for tuberculosis $(2.9 \%)$, and health worker strike $(2.3 \%)$. A few clients did not have the documents required for registration (ration card, proof of identification, voter card etc), while some others were taking traditional medicines or consulting temple priests and did not want ART. 
The reasons provided here highlight key barriers to enrollment at ART centers.

\section{Awareness about availability of free $A R T$}

Overall 82.9 per cent participants had received information about the availability of free ARV medications at government ART centers; and 77.5 per cent had been given referral slips for designated ART centers by the counsellors at ICTCs.

\section{PLHA network support}

Less than a fifth $(17.1 \%)$ had been introduced to a PLHA network member for support.

\section{Factors influencing registration at ART centers}

On bivariate analysis, significant differences $(p=0.05)$ were observed between participants who registered $(\mathrm{R})$ for ART services and those who did not register (NR) at ART centers. Differences were noted on age, educational level, marital status, disclosure of HIV status, knowledge of HIV-positive people in the community and certain economic indicators such as principal occupation of the household, living in a pucca house (made of bricks, stone or concrete), or owning a pressure cooker.

Younger participants, especially those under 30 years of age (R: 15.1\% vs. NR 20.1\%; p<0.086); illiterate participants (R: $54.1 \%$ vs. $65.1 \%$; p 0.022) and single/ never married participants were (R: $5.7 \%$ vs. NR: $10.6 \%$; $\mathrm{p}<0.04)$ were less likely to register for treatment. Further, the proportion of participants who had disclosed their HIV status to atleast one person was lower among those who did not register for treatment (R: $72.9 \%$ vs. NR: $54.8 \% ; \mathrm{p}<0.001)$; and a higher proportion of participants who did not register for treatment knew household(s) in the community with a HIV positive family member (R: $34.7 \%$ vs. NR: $51.1 \%$; $<0.001$ ). Differences on certain economic indicators were also observed, suggesting that participants with lower incomes or those who were economically weaker were less likely to register for treatment - participants who worked as manual labour (R: 52.5\% vs. NR: $66.1 \% ; \mathrm{p}<0.003$ ) were less likely to register for treatment. Participants living in a pucca (brick) house (R: $64.5 \%$ vs. $57.0 \%$; $\mathrm{p}<0.057)$ or those who owned a higher number of household goods $(\mathrm{P}<0.001)$ were more likely to register for treatment services.

There were no significant differences between groups with regard to gender, employment, having a family member on ART, owning agricultural land or owning a vehicle (bicycle, scooter, motor cycle). Satisfaction with ICTC counsellors and receiving referral slips were not significantly different between the two groups. CD4 cell counts were not included in this comparison as the majority of clients interviewed in the community had not undertaken this test at the time of interview.

The differences observed on bivariate analysis combined with the reasons given by participants who did not register for ART, provides a comprehensive view of barriers to uptake of ART services. 


\section{Conclusions}

The study was designed to document the uptake of ART services in the public sector and to determine the reasons why some people do not access these services even when they are available. A cohort of 1057 newly diagnosed HIV-positive people was followed over 2 months. Almost three-fourths $(73.5 \%$; $n=777)$ of the cohort registered at ART centers within two months of collecting their HIV test result. Of those who did not register at ART centers; 17.9 per cent $(n=189)$ were successfully interviewed in the community and 5.6 per cent $(n=60)$ were tracked but not interviewed and only around 3 per cent $(n=31)$ participants were untraced and lost to follow-up. This provides evidence to the program that clients can be successfully tracked in the community.

The majority of the HIV-positive participants, who did not register at ART centers and were interviewed in the community, were not accessing ART nor had undertaken CD4 tests to assess their eligibility for treatment. This places these clients at risk of delaying treatment. A small number of HIV-positive clients ( $\mathrm{n}=18)$ had registered at government ART centers in other districts for reasons of confidentiality, financial constraints and centers being close to their place of residence; however, this information was not available to the ICTC or referral ART center.

HIV-positive clients interviewed in the community did not register at referral ART centers for a variety of reasons. A perception of relatively good health removed the urgency to register immediately for several clients $(30 \%)$, while work and family engagements kept others away from the ART center $(22 \%)$. The fear of disclosure of their HIV status, being recognised by villagers or relatives and resulting stigma was the overriding concern for many others $(9 \%)$. Although ART is offered free at government centers, financial difficulties and travel expenses were deterrents for several participants $(9 \%)$. Family opposition comprised the fifth most commonly cited reason (5\%). Other reasons included the distance of ART centers compounded with severe illness, which prevented travel for the participants who probably needed ART most. In a few cases participants were waiting to complete their tuberculosis treatment prior to registering at ART clinics.

Study findings show that younger clients, single clients and clients working as unskilled manual labour were more likely to not register at ART centers. Further non-disclosure of HIV status and knowledge of HIV-positive people in the community were also associated with a higher probability of not registering at ART centers; highlighting the continuing role of stigma in the community. Additionally, indicators suggestive of financial incapacity (e.g. working as manual labour, not owning household goods such as pressure cookers or pans, fans, a sewing machine or a vehicle for transport) were significantly more likely not to register for ART services. Similar factors also emerged from the analysis of secondary data from ART centers in Phase 1 of this study. Further, these issues were also mentioned by clients who had registered at ART centers but continued to face difficulties while accessing services. If not addressed, these may be the very factors that contribute to non-adherence at a later stage.

Disclosure and stigma continue to be important barriers to accessing services. Intensive counselling and support to address and facilitate disclosure of HIV status and manage fears related to loss of confidentiality are urgently needed. 
The study also provides an assessment of the quality of counselling at ICTCs from interviews with HIV-positive people undertaken immediately after post-test counselling; and of the quality of counselling at ART centers from interviews conducted after registration at the ART centers. Overall clients were satisfied with counselling services at ICTCs. However, counselling at ICTCs and ART centers had some deficiencies. Topics that were inadequately covered included emphasis on partner testing, condom demonstration, explanation on the window period and information on PLHIV networks. Counselling at ART centers suffered from similar weaknesses, including insufficient information on the need for regular follow-ups and adherence to treatment, CD4 tests, and HIV testing of spouse and children. Health system issues, such as the shortage of HIV testing kits in ICTCs and health worker strikes also contributed to impeding registration at ART centers.

In conclusion, the majority of newly diagnosed HIV-positive people do register at ART centers. While barriers that deter HIV-positive people from accessing treatment services do exist, they are not insurmountable. Addressing client and health system barriers would serve to increase uptake of services.

\section{Recommendations}

- The study has demonstrated that programs can successfully track HIV positive persons in the community. Attempts must be made to track all newly diagnosed HIV positive people in the community. A two way process between the counsellor and HIV positive client is envisaged

a) Counsellors should routinely follow newly diagnosed positive people over two months after the HIV test, to determine whether they have registered at an ART center and reasons for not doing so, if they have not registered. This could be done through phone calls or outreach workers. ICTC registers would need to be modified to include additional information on registration at ART centers.

b) HIV positive clients must be asked to visit the ICTC or call the counsellor after they register at ART centers. While this is being done at some centers, implementation at a wider level may be considered.

- Enlisting support from PLHA networks for clients to reach ART centers is an important additional resource for health providers. This is not being implemented across all sites; this link can be strengthened to improve enrollment and follow-up in the community.

- ICTC counsellor's scope of work could be expanded to undertake an assessment of health and social status of newly diagnosed HIV positive people. The objective would be to identify persons who may be sick with advanced disease and in need of urgent medication; or having characteristics that may predict delayed registration or non-registration at ART centers - e.g. manual labourers, clients from a poor economic status, and illiterate clients who may require additional support to reach ART centers. Counsellors may be trained to initiate a more aggressive follow up plan for these clients.

- Healthy clients, on the other hand, would benefit from more focussed counselling on the importance of registering and assessing eligibility for ART even if they are in good health. 
- Several clients found travelling a long distance to ART centers burdensome for a variety of reasons - e.g. ill health, financial difficulties, lack of transport arrangements, not having people to accompany them etc. This is not only a barrier to uptake of ART services but also to long term adherence to treatment.

a) In low prevalence states, where ART centers receive clients from several districts or neighbouring states (as in the case of Varanasi), Link ART centers need to be established quickly. At present Link centers only provide delivery of ART medications, all checkups are done at referral ART centers. Weekly visits by specialists from the ART center and arrangements to collect and transport blood for CD4 cell counts could be considered.

b) Enlisting support of PLHA networks to accompany clients to ART centers should be encouraged.

c) Travel concessions on public transport could be provided.

- Fear of inadvertent disclosure of status and resulting stigma is an important barrier to seeking ART services. The program may consider offering choice of ART centers to newly diagnosed HIV positive people for the initial evaluation and registration, and long-term follow up. This would allow clients to register safely and without fear. Clients could move to center closer to their home once they felt comfortable with their HIV positive status and treatment.

- Closer monitoring of counselling at ICTCs and ART centers is required at the state and district level. Routine monitoring visits should be planned that include a review of service data as well as some exit interviews with clients and/or observation of counselling sessions where possible.

- Data quality issues were noted at both ICTC and ART centers.

a) Rigorous and regular monitoring of data quality at ICTCs and ART centers is urgently needed. Monitoring visits should include a review of registers.

b) Harmonization of data collection at ICTC and ART centers is required. Coding of key variables should be similar at both sites.

c) Linking of ICTC and ART center data is urgently needed for program monitoring. Client PID numbers (unique ID) should be recorded in ART registers to link the two data bases. A joint monthly review of linked data by ICTC counsellors and ART counsellors could ascertain the number of clients who registered successfully and those who did not register and therefore need to be tracked in the community. 


\subsection{Introduction}

India had an estimated 2.31 million (1.8 - 2.9) people living with HIV at the end of 2007, with a HIV prevalence of 0.34 per cent (NACO Annual Report, 200809). Despite the low HIV prevalence, these statistics place India among countries with a large number of people living with HIV (PLHIV). Providing treatment, care and support services for this population is a challenging task for the public health care system both as a national program and at the state level.

India has a large network of public health facilities distributed across rural and urban areas that provide free health care to the population. HIV testing is available at Integrated Counselling and Testing Centers (ICTCs) located in government health facilities in almost all districts across the country. At the end of March 2009, there were 2487 ICTCs in India, and 10,200,000 people had been tested for HIV at the centers in 2008-09 (NACO Annual Report, 200809). India also has large and active private health care system where HIV testing and antiretroviral therapy (ART) is available for a fee. Anecdotal information suggests that HIV testing is undertaken prior to most surgical and gynaecological procedures including deliveries.

To address the care and support needs of PLHIV, the Ministry of Health and Family Welfare (MOH FW), Government of India, initiated a national programme in 2004 to provide free ART for PLHIV. The model for delivery of ART adopted by the National AIDS Control Organisation (NACO) is a centralized institutional model supported by Non

Government Organisations (NGOs) and Community Based Organisations (CBOs). The programme envisages community involvement for tracking HIVpositive people receiving treatment with the help of trained paramedical personnel, community workers and people living with HIV/AIDS. Community Care Centers (CCCs) were set up to support services. All HIV-positive people are required to be tested at a government ICTC prior to being registered at the ART centers (ARTC); thus clients tested in the private sector are required to undergo a repeat HIV test at the ICTC in order to receive ART. To expand the geographic reach of treatment services, ART centers covering large geographical areas have associated Link ART centers placed at ICTCs or CCCs; especially in the low prevalence northern states that have a smaller network of ART centers. Link ART centers have the potential to be upgraded into functioning ART centers. At the end of March 2009, there were 211 functioning ARTCs and 254 CCCs across the country, and to date 2,17,781 are receiving ART. NACO aims to reach 300,000 adult PLHIV and 40,000 children living with HIV through 250 ARTCs and 650 Link ARTC by 2012 (NACO Annual report 2008-09).

A major challenge for the health system with its network of ART centers has been to increase utilization of ART services and enrolment into the program. Counsellors at ICTCs are expected to advise all newly diagnosed HIV-positive people to register at ART centers for further care including an evaluation of eligibility to initiate ART. However, anecdotal information suggests that less than 20 per cent of HIV-positive individuals who need treatment access it at ART centers. Barriers may include financial, social and organizational factors. Financial barrier is the largest obstacle 
in both public and private healthcare sectors. Despite the provision of free antiretroviral (ARV) medications and CD4 tests, patients have to spend out of pocket on other laboratory investigations (e.g. radiological, blood tests, etc), nutritional supplements and transport costs (Sarna et al 2006, 2008). Additionally, families often have multiple HIV infected members (parents and children) who need treatment, increasing the financial burden on families with limited resources (Sarna et al, 2007). Social barriers such as stigma, discrimination, gender inequality, and lack of education also represent great challenges to HIV-positive individuals and their further access to treatment.

India's thriving private health sector delivers around three-fourths of all health care services and comprises 74 per cent of the total health expenditure in the country (World Bank, 2007). The widespread utilisation of the private sector and traditional practitioners in the country suggests that they are trusted, accessible, and affordable practitioners. Furthermore, $\mathrm{HIV} / \mathrm{AIDS}$ is still associated with significant stigma/ taboo which may prevent people from accessing care from designated ART centers and draw patients to the private sector for reasons of confidentiality (Sarna et al 2006). Additionally, people also carry negative perceptions of government healthcare centers for reasons such as improper behaviour of health staff, staff shortages, a lack of supplies and drugs, and long waiting times to see a doctor (Bhat et al, 2004). 


\subsection{The Project}

As NACO expands the network of ART centers it is important to understand the factors that contribute to utilization of ART services by HIV infected individuals. The Population Council, with support from NACO, undertook a multi-site study from April 2009 to March 2010 in four high HIV prevalence and three low HIV prevalence states to understand the context and factors that influence the uptake of ART services. The study was designed to provide guidance to the national HIV/AIDS control program on developing programmatic strategies to promote enrolment of HIV-positive individuals at ART centers aimed at increased service utilization and better care for HIV infected individuals. The study was conducted in two phases.

In the first phase we undertook analysis of secondary data collected from ICTCs and ARTCs in the study districts. A qualitative component was included to provide insights for designing the Phase 2 cohort study. We conducted focus group discussions with HIV positive persons from PLHA networks and with health workers. In-depth interviews were also conducted with PLHIV receiving services at ARTCs.

In the second phase, we conducted a prospective observational cohort study among newly diagnosed HIV-positive people tested at ICTCs. Individuals who tested positive at selected ICTCs were recruited into the study and followed till their registration at the referral ART center. Those who did not register at the referral ART center were tracked in the community for a follow-up interview.

This report is structured to follow the study format. Part One describes the study methodology, site selection and results for Phase 1 dealing with the collection and analysis of secondary data from ICTCs and ARTCs while Part Two describes the cohort study.

\subsection{Objectives}

The global objective of this study was to understand the barriers that prevent HIV-positive people from accessing ART services to inform programmatic strategies to improve uptake of ART services.

The specific objectives of the project were to:

1. Understand the profile and characteristics of individuals who test HIV-positive at ICTCs.

2. Understand the profile and characteristics of $\mathrm{HIV}$-positive people registered at ART centers for HIV care and treatment.

3. Compare the socio-demographic characteristics of people diagnosed HIV-positive at ICTCs with those accessing ART services to determine profiles or sub-groups of PLHIV who may not reach ART centers.

4. Assess the individual, familial, socio-cultural and structural barriers that affect enrolment of newly diagnosed HIV-positive individuals at ART centers.

\subsection{Selection of study districts and study sites}

To obtain a broad view of the ART program across the country, the study was conducted in four high prevalence and three low prevalence states in India. States and study districts were selected in consultation with NACO at a technical resource group meeting that included representatives from five Centers of 
Excellence for ART services and NACO senior staff. Study districts and corresponding ART centers were selected based on HIV prevalence in the state (category A and B districts), client load at the ART centers and the network of ICTCs in the catchment area of ART centers.

Two districts were selected in the high prevalence states of Maharashtra, Karnataka and Andhra Pradesh. In Manipur only one district was selected due to the overall size of the state, logistical concerns and the presence of two ART centers in Imphal where most clients were referred. One district was selected in each of the low prevalence states of Uttar Pradesh, Rajasthan and Gujarat. Selection criteria for ART centers included a minimum of 1000 cumulative HIV-positive clients registered at the ART center in the district and monthly rate of at least 30 new registrations per month.

In the high prevalence states, three large volume ICTCs that referred clients to the ART center were selected in each district. In the low prevalence states each ART center has a wider geographical coverage and usually receives clients from ICTCs from surrounding districts. For Phase 1, the committee selected one ICTC from within the district and two ICTCs from outside districts in the three low HIV prevalence states; the aim was to utilise the wider geographical coverage to identify barriers faced by clients accessing services at ICTCs and ART centers. In all states one ICTC was located in the same hospital as the ART center.

A mapping exercise was conducted to select high volume feeder ICTCs. The research team gathered information on the ICTCs referring HIV-positive people to each of the selected ART centers, specifically focussing on the number of clients tested per month, average number of HIV-positive people diagnosed per month, geographical coverage of the ICTCs and closest ART center. Geographical coverage extended to neighbouring states for some ART centers. A final selection was made in consultation with District State AIDS Control officials, Senior Medical Officers incharge of the ART centers and health care staff at the clinics.

For the cohort study (Phase 2), based on feedback from health workers in the field, it was decided not to select the ICTCs located within the same hospital as the ART centers, since almost all the newly diagnosed HIV-positive people reached ART centers quite easily. Therefore, in Phase 2, three high volume ICTCs outside the hospital were selected for each ART center. In the low prevalence states these ICTCs were located in different districts.

Thus in each district one ARTC and three corresponding feeder ICTCs were selected: a total of 30 ICTCs across 10 districts in seven states were included in Phase 1 of the study. Manipur was not included in Phase 2 due to administrative and logistical reasons. Phase 2 was conducted in six states with a total of 9 ART centers and 27 ICTCs. Selected districts and sites are shown in Table 1.

\subsection{Ethical Approval}

Ethical approval for the study was obtained from the Institutional Review Board of the Population Council and from the Technical Resource Group on Research and Development, NACO and the NACO Ethics Committee for Research at NACO. Data collection instruments and informed consent forms were approved by both bodies. 
The Project

Table 1: State-wise list of participating ART Centers and ICTCs

\begin{tabular}{|c|c|c|c|}
\hline State & District & ARTC & ICTC \\
\hline \multirow[t]{8}{*}{ Andhra Pradesh } & Krishna & District Hospital, Vijawada & Vijawada $^{1}$ \\
\hline & & & Gudivada \\
\hline & & & Nandigama \\
\hline & & & Mylavaram $^{2}$ \\
\hline & East Godavari & District Hospital, Rajamundhry & Rajamundhry ${ }^{1}$ \\
\hline & & & Mandapeta \\
\hline & & & Gokavaram \\
\hline & & & Kadiam $^{2}$ \\
\hline \multirow[t]{8}{*}{ Maharashtra } & Kolhapur & District Hospital, Kolhapur & Kolhapur $^{1}$ \\
\hline & & & Ichalkaranji \\
\hline & & & Gandigal \\
\hline & & & $\mathrm{Kagal}^{2}$ \\
\hline & Satara & District Hospital, Satara & Satara $^{1}$ \\
\hline & & & Phaltan \\
\hline & & & Karad \\
\hline & & & $\operatorname{Patan}^{2}$ \\
\hline \multirow{8}{*}{ Karnataka } & Bijapur & District Hospital, Bijapur & Bijapur $^{1}$ \\
\hline & & & Bagewadi \\
\hline & & & Indi \\
\hline & & & Muddebihal $^{2}$ \\
\hline & Bagalkot & District Hospital, Bagalkot & Bagalkot $^{1}$ \\
\hline & & & Jamalkhandi \\
\hline & & & Mudhol \\
\hline & & & Badami $^{2}$ \\
\hline \multirow[t]{3}{*}{ Manipur ${ }^{c}$} & Imphal & Rajiv Gandhi Institute of Medical Sciences, Imphal & RIMS \\
\hline & & & MLSS \\
\hline & & & Bishenpur \\
\hline \multirow[t]{4}{*}{ Rajasthan } & Jaipur & SM Singh Medical College, Jaipur & Jaipur $(\mathrm{SMC})^{1}$ \\
\hline & & & Alwar \\
\hline & & & Sikar \\
\hline & & & Ajmer $^{1}$ \\
\hline \multirow[t]{4}{*}{ Uttar Pradesh } & Varanasi & Banaras Hindu University, Varanasi & 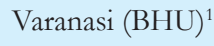 \\
\hline & & & Azamgarh \\
\hline & & & Jaunpur \\
\hline & & & Bhadoi $^{2}$ \\
\hline \multirow[t]{4}{*}{ Gujarat } & Mahesana & District Hospital, Mahesana & Mahesana $^{1}$ \\
\hline & & & Palanpur \\
\hline & & & Patan \\
\hline & & & $\mathrm{Kadi}^{2}$ \\
\hline
\end{tabular}




\subsection{Secondary Data from ICTC and ART centers}

\subsection{Methods}

A cross-sectional study design was used for secondary data analysis of existing information from ICTC and ART centers. At ICTC, data were collected from the locator register (PID Register for general clients, ICTC register for general clients) and the HIV test register for all clients over 15 years of age who tested positive at participating ICTCs between October 1, 2008 and March 31, 2009. Information collected included: sociodemographic information (age, sex, education, employment, and marital status), referred from, referred to, and residential district. Route of infection, partner testing and partner HIV test results were also recorded. HIV testing facilities located at PPTCT centers were not included in this study.

At ART centers data were collected from the Pre ART Registration records (register), ART cards (white cards) and Laboratory registers for all HIV-positive people over 15 years of age who registered at participating ARTCs between October 1, 2008 and March $31,2009$.
Results from the secondary data analysis are presented in three parts: first for data collected from ICTCs, followed by data collected from ARTCs and then comparisons between ICTCs and ARTCs. Data is presented by state and, where essential, gender comparisons have been made.

\subsection{Limitations and challenges}

NACO instituted a standardized data collection system across all ICTCs and ART centers in the country through centrally printed and distributed registers. However, transition to new registers took place at different time periods resulting in data variability across sites prior to the end of 2008, for example, missing variables or differently coded variables. Quality of data was also variable across centers and there was significant missing information on key variables. Further, similar variables were coded differently at ICTCs and ART centers preventing comparisons. The findings presented in this report are based on existing data collected from the registers at selected centers. 


\subsection{Integrated Counselling and Testing Centers}

A total of 7814 people tested HIV-positive between October 1, 2008 and March 31, 2009 across the 30 participating ICTCs. Table 2 shows the distribution of clients recruited by state and district, and the proportion of clients who resided in the same district as the ICTC.

Table 2: Distribution of HIV-positive people by state, district and ICTCs

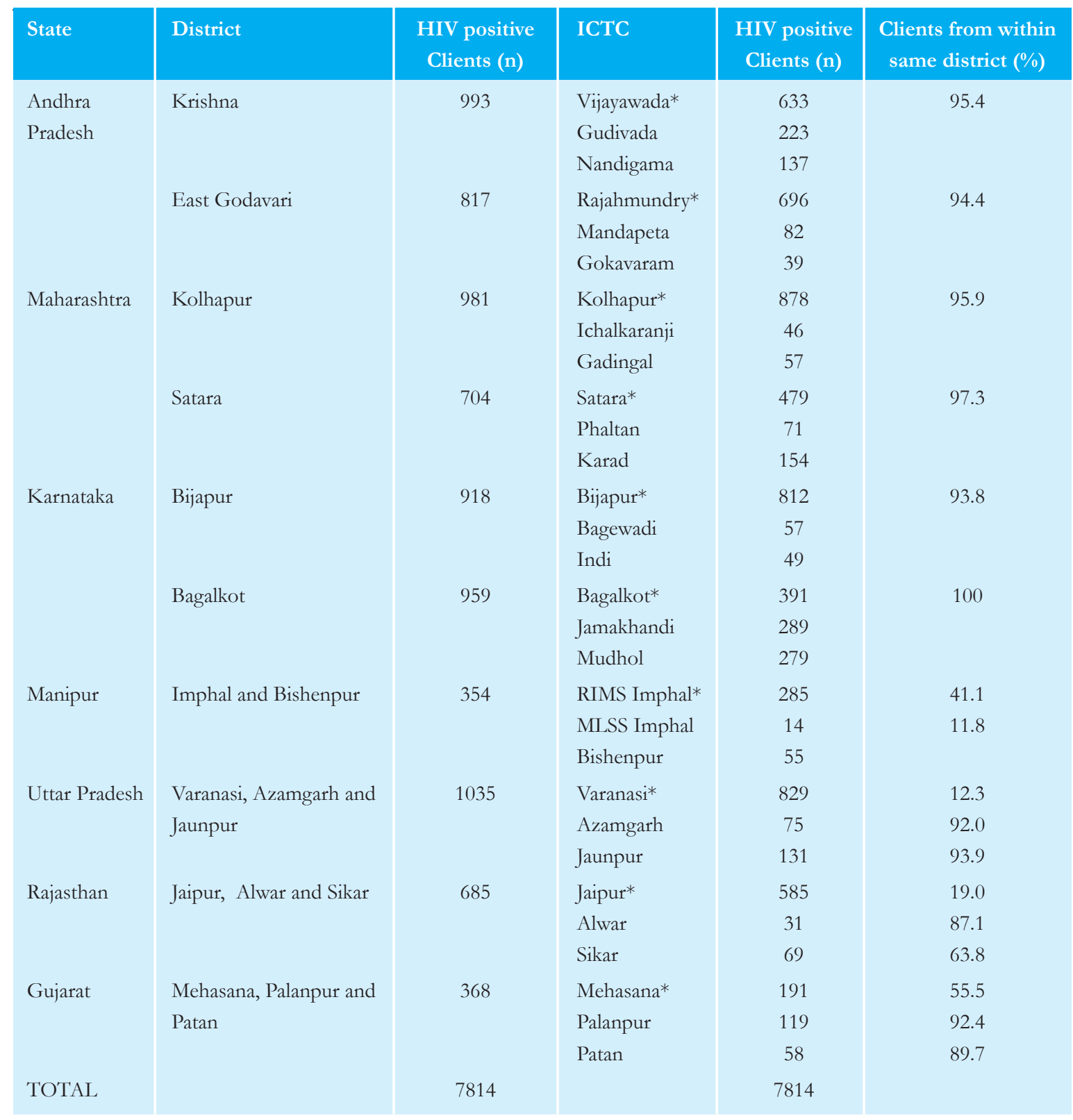

* ICTCs located in same referral hospital as the ART center 
As expected, high HIV prevalence states had a larger number of newly diagnosed HIV-positive clients compared to the low prevalence states with the exception of Manipur and Uttar Pradesh (UP) (Table 1). UP, a low prevalence state, reported the largest number of newly diagnosed HIV-positive clients $(\mathrm{n}=1035)$ for the six month reference period. The ICTC in Varanasi received clients from a large geographical area including some districts of neighbouring Bihar, Jharkhand and Madhya Pradesh. Despite being a high prevalence state, Manipur had the lowest number of newly registered HIV-positive clients in the preceding six months $(\mathrm{n}=354)$. Most participants coming from districts outside Imphal were referred directly to the ARTC at RIMS by NGOs, lowering the numbers tested at other ICTCs located in Manipur. In all states the highest number of HIV-positive clients came from ICTCs located in the same hospital as the ARTCs. These ICTCs serve as an entry point for several clients from outside districts and a wider geographical area that have been referred from the private sector or NGOs.

\subsection{Gender}

Overall 56 per cent were males and 44 per cent females. One client self-identified as a transgender and was considered a male for the purpose of analysis. The mean age for all clients was 35.4 years (SD 9.1) and the median age was 35 (IQR 30, 40). Males were significantly older than female clients (mean age males: 37.1 years (SD 9.1) vs. females 33.3 years (SD 8.6); $\mathrm{p}<0.001 \mathrm{~T}$ test). The age of clients ranged from 15 to 83 years for males and 15 to 73 years for females. There were substantial differences in the distribution of males and females across states. Low prevalence states of Uttar Pradesh, Rajasthan and Gujarat had a substantially higher proportion of male clients compared to female clients (Figure 1). In the high prevalence states there were also more male clients, however, the differences between the sexes was smaller; women formed between 44 to 47 per cent of clients tested HIV-positive.

Figure 1: Gender distribution of HIV positive clients by state (ICTC)

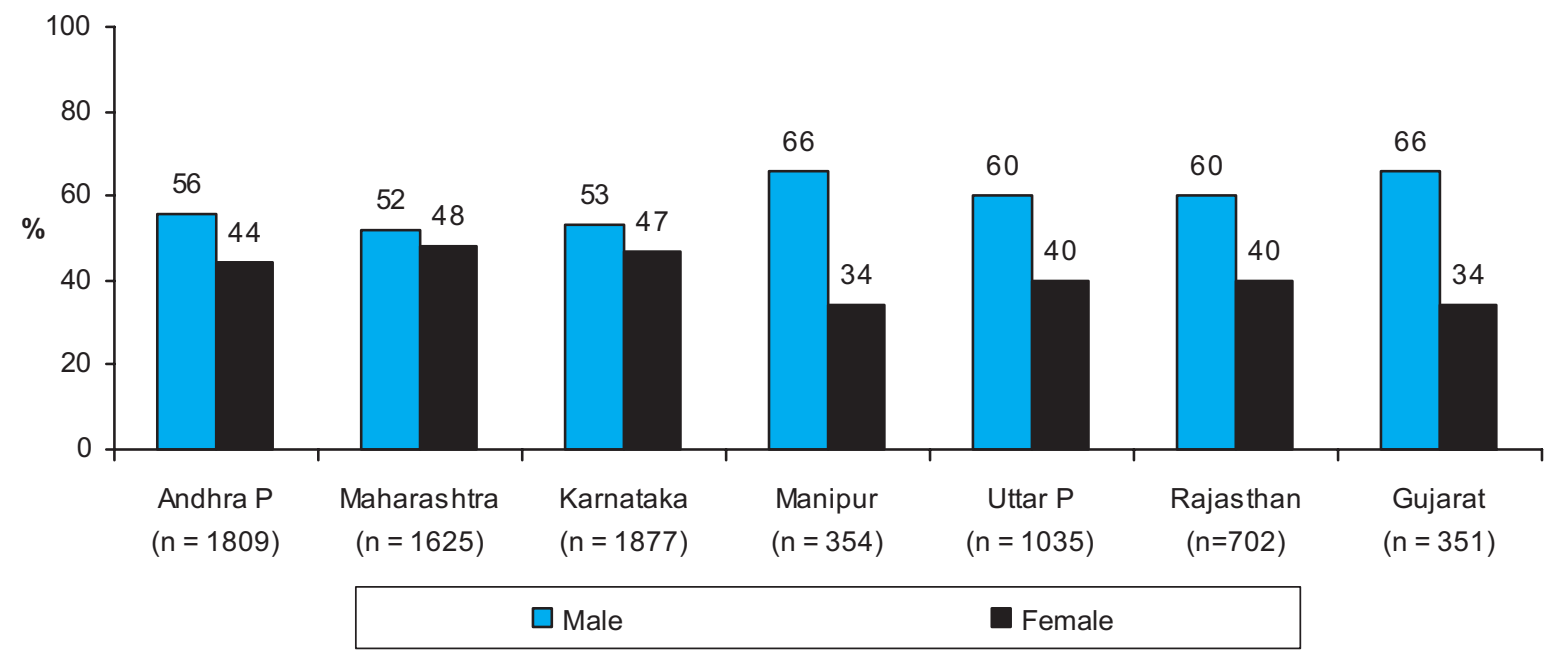




\subsection{Marital status}

Overall, the majority of clients, 78.4 per cent, across all states were currently married; 5.7 per cent were single (never married), 1.8 per cent were separated or divorced and 14 per cent were widowed. Maharashtra and Manipur had the lowest proportion of married clients (69\%). In Maharashtra a quarter (25\%) of all clients were widowed and in Manipur a fifth of all clients were single. Significant gender differences were observed. Males clients were more likely to be married compared to female clients $(86.3 \%$ vs. $68.3 \%$; $\mathrm{p}<0.001)$ while female clients were more likely to be widowed compared to males $(26.5 \%$ vs. $4.3 \%$;

$p<0.001)$. Data on HIV testing for spouses was available only for 53 per cent $(n=3259)$ of married participants $(\mathrm{n}=6037)$. Among the married clients, 54.8 per cent $(\mathrm{n}=1787)$ of spouses had undertaken HIV tests; 80.5 per cent spouses were HIV-positive and 19.5 per cent were HIV-negative.

Figure 2: Marital status of HIV positive clients by state (ICTCs)

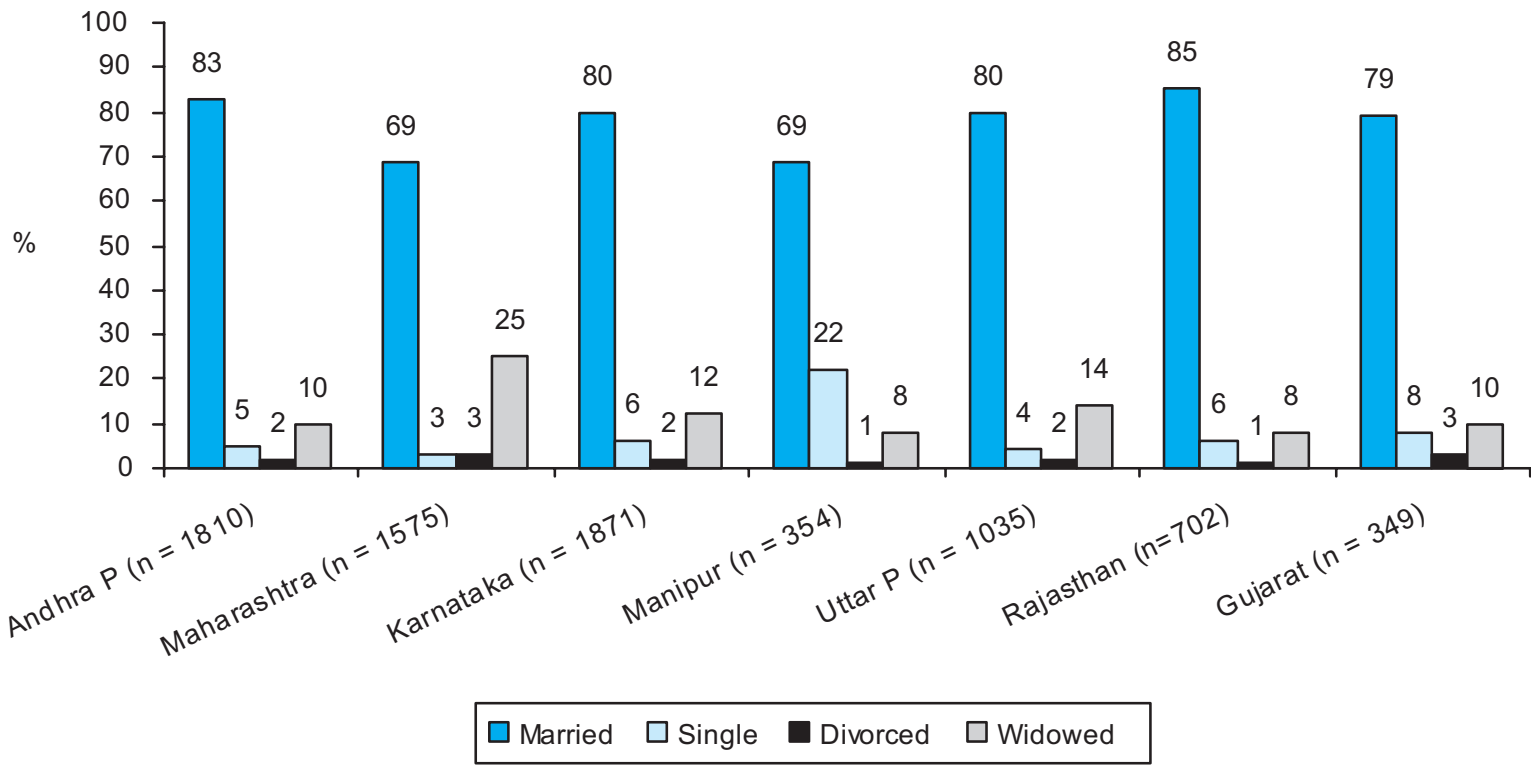

\subsection{Education level}

Information on the educational level of clients accessing services at ICTCs is collected routinely. Overall 41.9 per cent of the newly diagnosed HIV-positive clients were illiterate, 28 per cent of the clients had completed primary schooling, 22.7 per cent had completed secondary school and only 7.4 per cent had a college education, per ICTC registers. Karnataka had the highest proportion of illiterate clients (65\%), possibly due to the large rural population accessing services. Both Bijapur and Bagalkot are small towns in rural areas. Manipur recorded the highest proportion of clients with a secondary education (44\%) and college level education (19\%). 
Figure 3: Educational level of clients by state (ICTC)

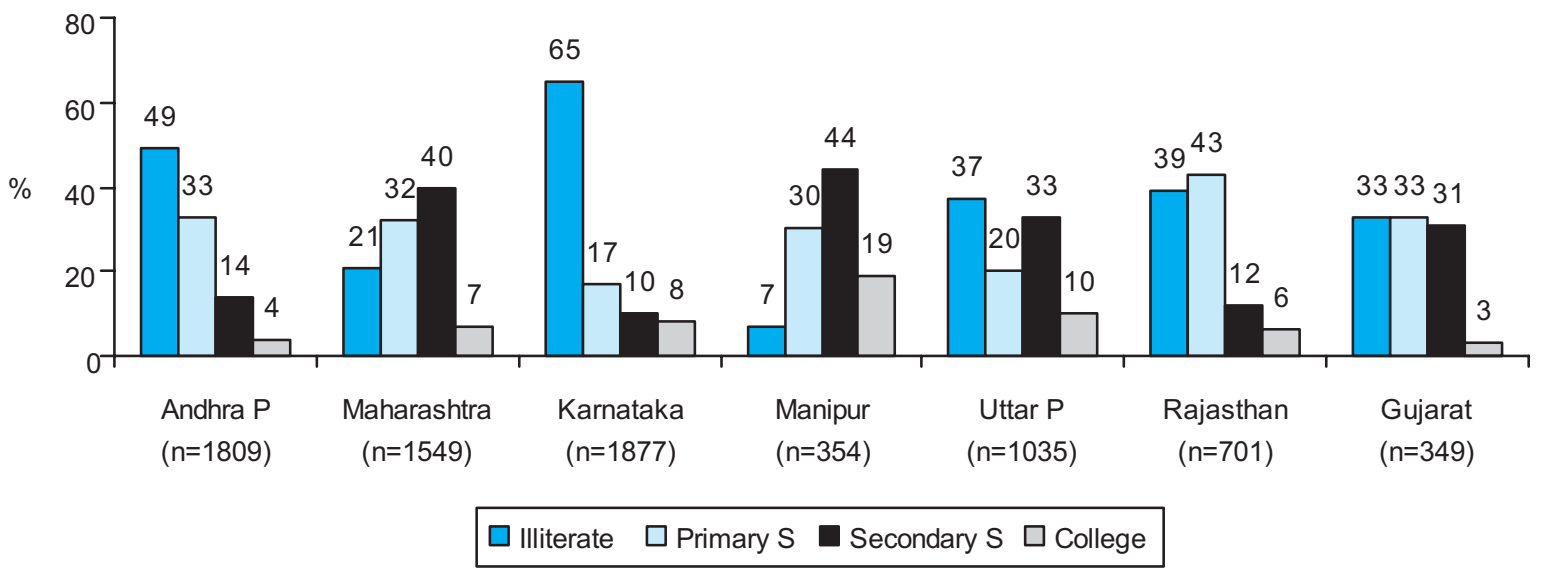

\subsection{Occupational status}

Overall 51.5 per cent of all clients $(\mathrm{n}=7631)$ across all states were working as daily wage or unskilled labourers, 10.2 per cent were salaried employees, 9.6 per cent ran businesses, 0.3 per cent were retired and 0.7 per cent were students. Additionally, 21.1 per cent of clients are recorded as being house-wives, these included 44 male clients; and 6.6 per cent were categorized as 'other'. ICTC registers do not record unemployment data and occupational data collected at ICTCs does not allow us to make this distinction. It is possible that unemployed clients may be coded under housewives and others. It is interesting to note that Karnataka and Andhra Pradesh with the highest proportion of illiterate clients also reported the highest proportion of clients working as unskilled manual labour.

Figure 4: Occupational status of clients by state (ICTC)

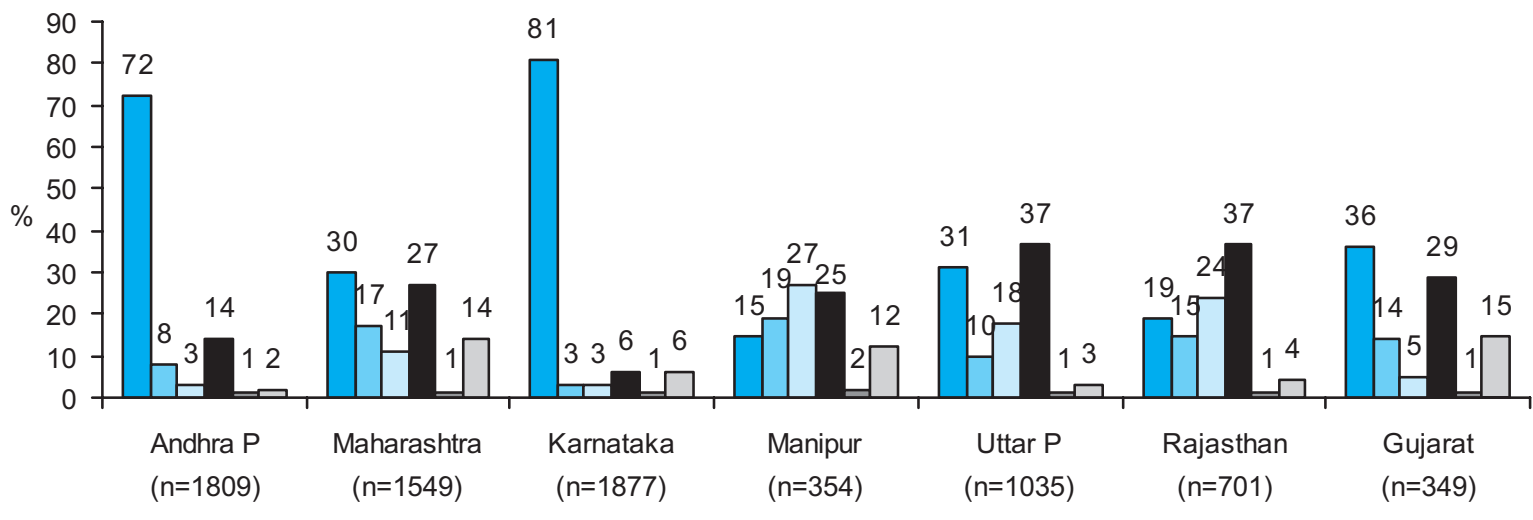

$\square$ Daily wage $\square$ Salaried $\square$ Business $\quad \square$ Housewife $\quad \square$ Retired/student $\square$ Other 


\subsection{Route of Infection}

The overall route of infection for the majority of clients $(90 \%)$ was recorded as heterosexual exposure in ICTC registers. All other routes of infection were mentioned for less than 3.5 per cent of clients. Differences were observed across states. In Manipur clients infected as a result of injecting drug use constituted 26.6 per cent. The route of infection for 22.5 per cent of clients was not specified in Uttar Pradesh and for 9.3 per cent clients in Rajasthan, suggesting that clients may be hesitant to provide information in low HIV prevalence states where the HIV is not as widespread.

The majority of HIV-positive clients were referred to ART centers. The proportion of HIVpositive clients referred to ART centers was the lowest in Manipur (60.7\%). As injecting drug use is a common source of HIV infection in this population, counsellors at ICTCs often refer HIV infected injection drug users (IDUs) to NGOs for social support and assistance guiding these people to the ART center.

Table 3: Routes of HIV infection and ARTC referral for clients by state (ICTC)

\begin{tabular}{|c|c|c|c|c|c|c|c|c|}
\hline & $\begin{array}{c}\text { Andhra } \\
\text { Pradesh } \\
\% \\
(n=1804)\end{array}$ & $\begin{array}{c}\text { Maha- } \\
\text { rashtra } \\
\% \\
(n=1493)\end{array}$ & $\begin{array}{c}\text { Karnataka } \\
\% \\
(\mathrm{n}=1877)\end{array}$ & $\begin{array}{c}\text { Manipur } \\
\% \\
(n=354)\end{array}$ & $\begin{array}{c}\text { Uttar } \\
\text { Pradesh } \\
\% \\
(\mathrm{n}=1034)\end{array}$ & $\begin{array}{c}\text { Rajasthan } \\
\% \\
(n=701)\end{array}$ & $\begin{array}{c}\text { Gujarat } \\
\% \\
(n=351)\end{array}$ & $\begin{array}{c}\text { Total } \\
\% \\
(\mathrm{n}=7614)^{1}\end{array}$ \\
\hline \multicolumn{9}{|l|}{ Route of HIV Infection } \\
\hline Heterosexual & 96.4 & 95.1 & 92.1 & 70.3 & 75.1 & 88.7 & 89.2 & 90.0 \\
\hline Homosexual & 2.3 & 0.5 & 0.5 & 0.3 & 0.1 & 0.6 & 2.8 & 1.0 \\
\hline Blood transfusion & 0 & 1.3 & 0.2 & 1.7 & 1.6 & 0.1 & 0.3 & 0.6 \\
\hline Exposure at health facility & 0.4 & 0.5 & 0.5 & 0 & 0.4 & 0.1 & 0 & 0.4 \\
\hline Parent to child & 0.2 & 0.3 & 0.2 & 0.6 & 0 & 1.0 & 1.4 & 0.3 \\
\hline IDU & 0.6 & 0.1 & 0.1 & 26.6 & 0.2 & 0.1 & 0.3 & 1.5 \\
\hline Not specified & 0.1 & 2.2 & 6.4 & 0.6 & 22.5 & 9.3 & 6.0 & 6.2 \\
\hline \multicolumn{9}{|c|}{ Referred to ART center by counsellor } \\
\hline & $\mathrm{n}=1808$ & $\mathrm{n}=1166$ & $\mathrm{n}=1373$ & $\mathrm{n}=354$ & $\mathrm{n}=1035$ & $\mathrm{n}=621$ & $\mathrm{n}=347$ & $\mathrm{n}=67041$ \\
\hline Referred to ARTC & 100 & 90.2 & 95.2 & 60.7 & 90.2 & 98.2 & 99.1 & 70.8 \\
\hline
\end{tabular}

${ }^{1}$ denominators vary due to missing data 


\subsection{ART Centers}

A total of 11568 HIV-positive people registered for treatment between October 1, 2008 and March 31, 2009 across the 10 participating ART centers.

Table 4 shows the distribution of clients recruited by state and district, and the proportion of clients who resided in the same district as the ART center. As expected, the ART centers in high prevalence states registered more clients during the reference period compared to centers in low prevalence states. In high prevalence states, the majority of clients registering at ART centers resided in the same district as the ART centers. By contrast, in the low prevalence states, the majority of clients came from outside districts, or as in the case of the ART center at Varanasi, UP, from districts in neighbouring states such as Bihar, Jharkhand and Madhya Pradesh.

Table 4: Distribution of HIV-positive people registering at ART centers by state and district

\begin{tabular}{|c|c|c|c|}
\hline State & District & Clients registered (n) & $\begin{array}{l}\text { Clients from within } \\
\text { same district }(\%)\end{array}$ \\
\hline \multirow[t]{2}{*}{ Andhra Pradesh } & Krishna & 2620 & 96.8 \\
\hline & East Godavari & 1129 & 94.1 \\
\hline \multirow[t]{2}{*}{ Maharashtra } & Kolhapur & 1185 & 96.3 \\
\hline & Satara & 1274 & 99.6 \\
\hline \multirow[t]{2}{*}{ Karnataka } & Bijapur & 1479 & 83.9 \\
\hline & Bagalkot & 1536 & 94.7 \\
\hline Manipur & Imphal & 283 & 56.5 \\
\hline Uttar Pradesh & Varanasi & 724 & 10.4 \\
\hline Rajasthan & Jaipur & 701 & 17.5 \\
\hline Gujarat & Mehasana & 637 & 32.3 \\
\hline TOTAL & & 11568 & \\
\hline
\end{tabular}

\subsection{Gender}

Overall 51.1per cent of clients registering at ART centers across all states were male. There were gender differences across states. (Figure 5) The high prevalence states of Maharashtra (51\%) and Karnataka (52\%) registered more females than males, while Andhra
Pradesh had marginally more male than female clients. Despite being a high prevalence state, Manipur had significantly more male clients; possibly due to the fact that injecting drug use is more common among men, leading to more HIV infections among men. The low prevalence states had substantially fewer female clients. 
Figure 5: Gender distribution of clients by state (ARTC)

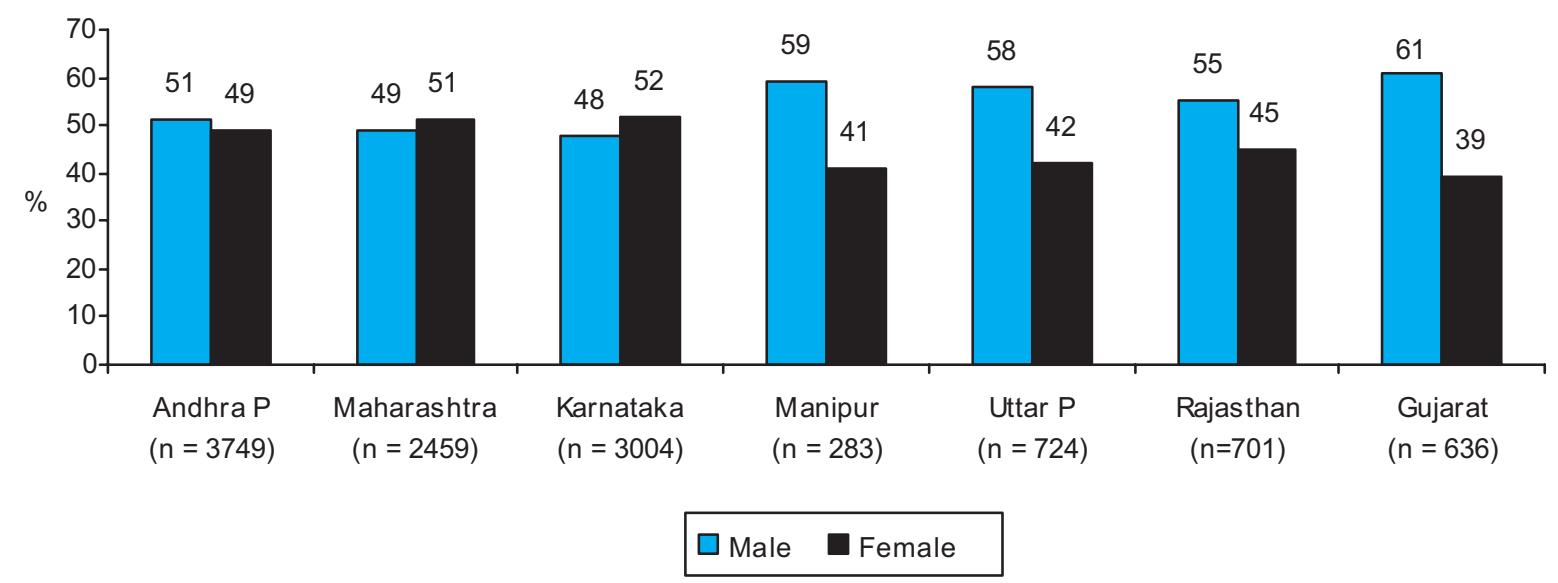

\subsection{Marital status}

Across all states the majority of clients, 70.7 per cent, were currently married, 20.6 per cent were widowed, 5.8 per cent were single (never married) and 2.0 per cent divorced or separated. Around a quarter of the clients registering in Maharashtra (27\%), Karnataka
(24\%) and Uttar Pradesh (23\%) were widowed.

(Figure 6). There were significant gender differences; males were more likely to be currently married compared to female clients $(82.6 \%$ vs. $57.9 \%$; p < 0.001) while females were more likely to be widowed compared to male clients $(35.3 \%$ vs. $6.8 \%$; $<<0.001)$.

Figure 6: Marital status of clients by state (ARTC)

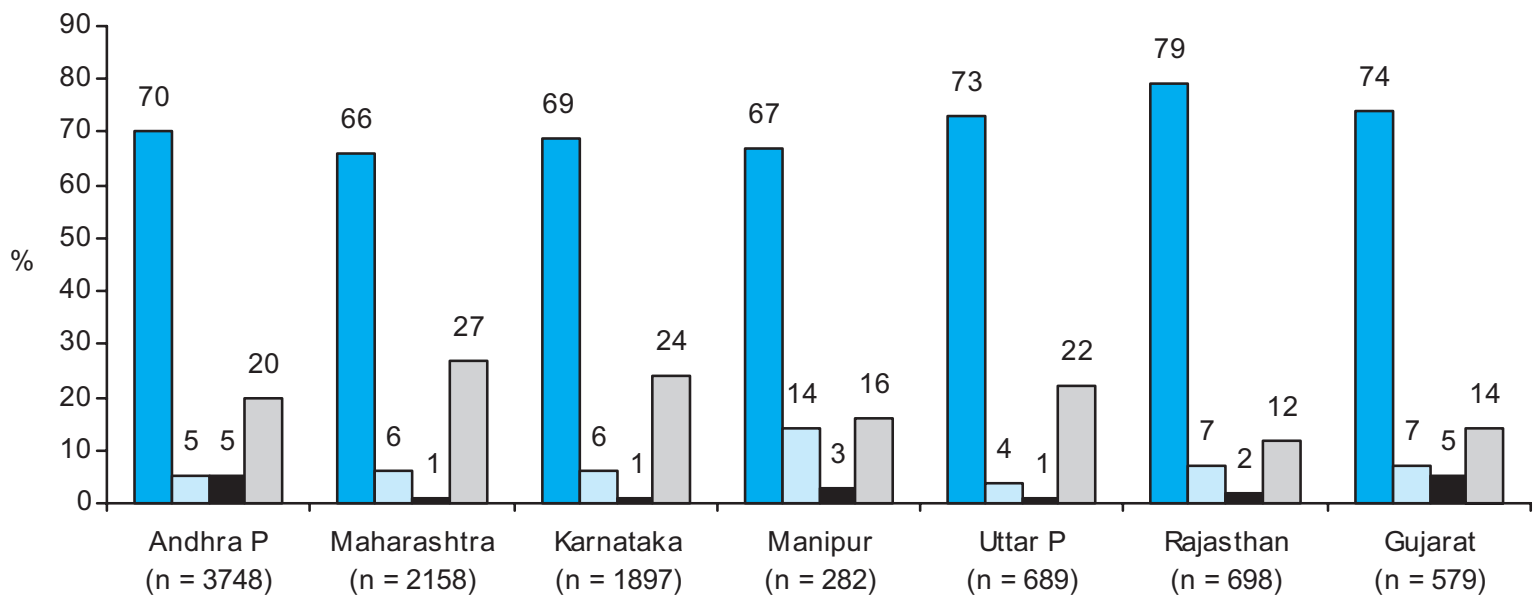

$\square$ Married $\square$ Single $\square$ Separated $\square$ Widowed 


\subsection{Education level}

Overall, 50 per cent of the clients registering at ART centers during the reference period were illiterate, 21.8 per cent had completed primary school, 21.7 per cent had completed secondary school and only 6.4 per cent had a college education. Karnataka had the highest proportion of illiterate clients $(69 \%)$ followed by Andhra Pradesh (54\%) (Figure 7). A third of the clients in Manipur had completed secondary school and 21 per cent a college education. There were gender differences in education level among clients; female clients were more likely to be illiterate compared to male clients (59.2\% vs.41.2\%; $\mathrm{p}<0.01)$.

Figure 7: Educational level of clients by state (ARTC)

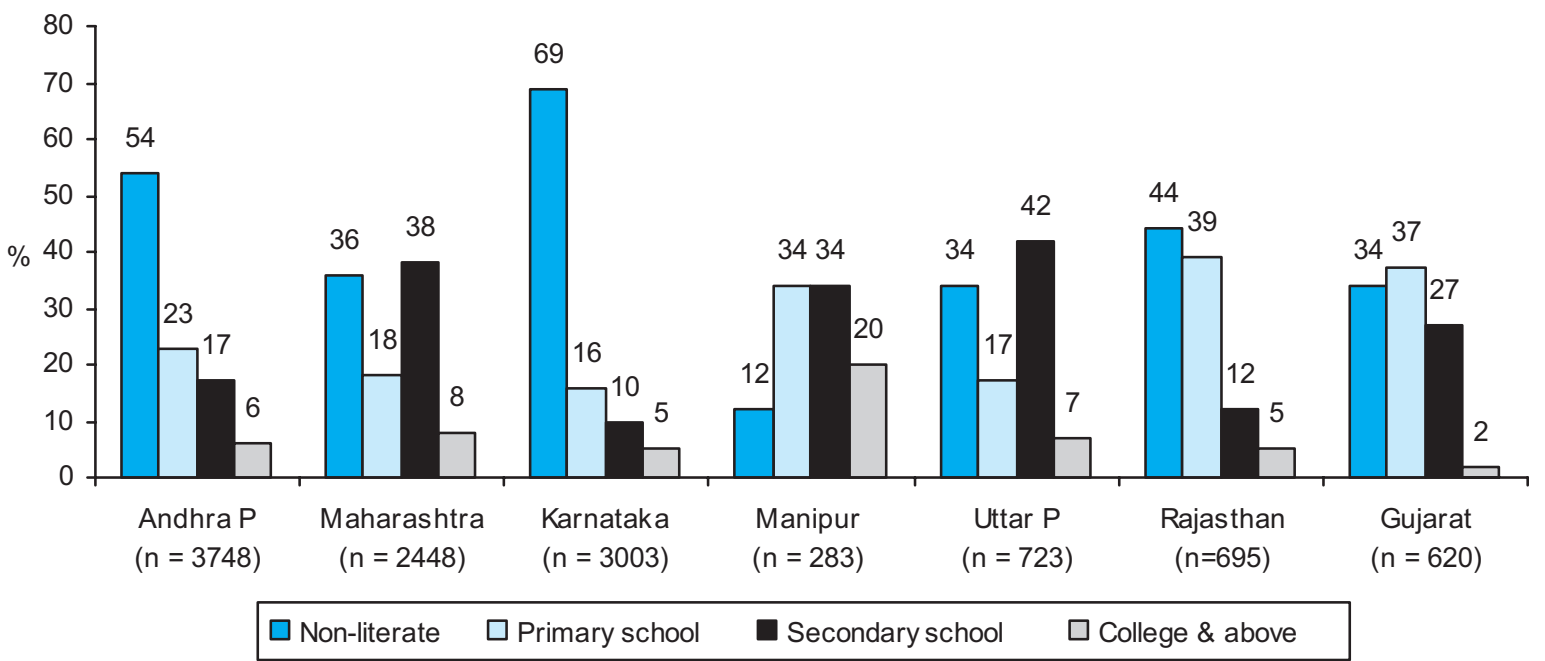

\subsection{Employment status}

Overall, the majority of clients, 81.2 per cent, registering at ART centers were unemployed. The states of
Maharashtra and Rajasthan had a higher proportion of employed clients (Figure 8).

Figure 8: Employment status of clients by state (ARTC)

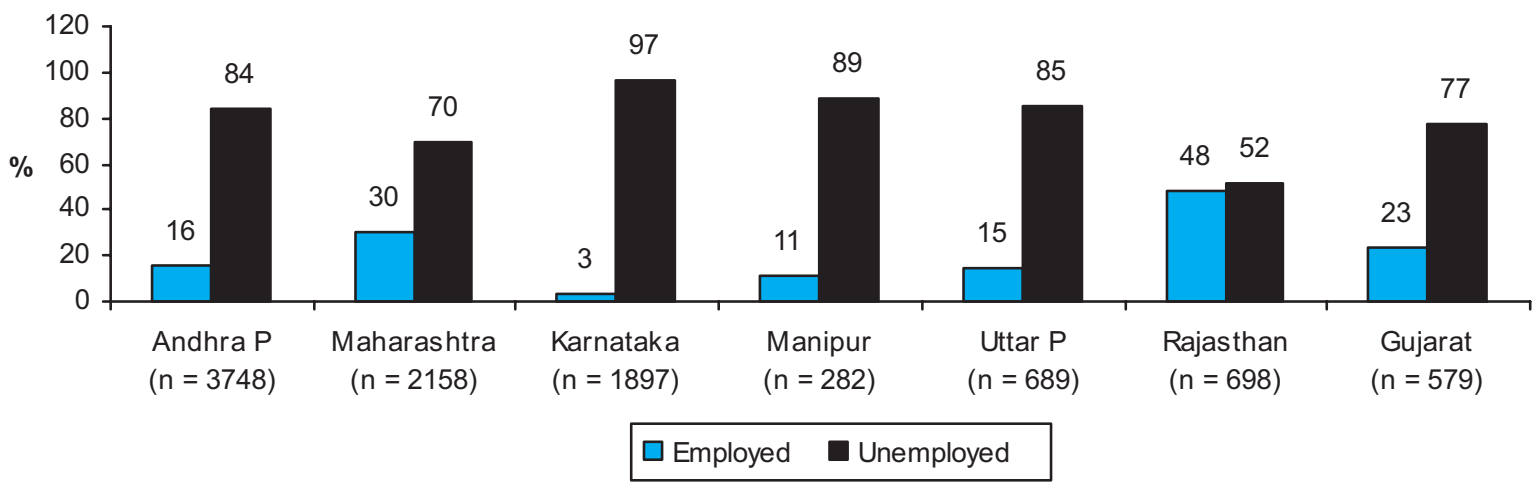




\subsection{Immune status: CD4 cell counts}

The hallmark of HIV disease is the gradual destruction of the body's immune system allowing opportunistic infections and causing weakness. HIV-positive clients with advanced disease are often too sick to work. To assess eligibility for initiating ART, newly diagnosed HIV-positive clients are asked to undertake a CD4 count test. Figure 9 presents the distribution of CD4 cell counts for newly diagnosed HIV-positive clients registering at ART centers. It is interesting to note that states like Karnataka, Manipur and Uttar Pradesh with higher rates of unemployment also had a higher proportion of clients with CD4 cell counts $<250$ cells $/ \mathrm{ml}$. [Note: data on CD4 counts from laboratory and ART registers was available for 8325 clients (missing data for clients who did not undertake the test, did not collect the result or in some cases where report was handed over to the client)].

Figure 9: Immune status of HIV positive clients by state (ARTC)

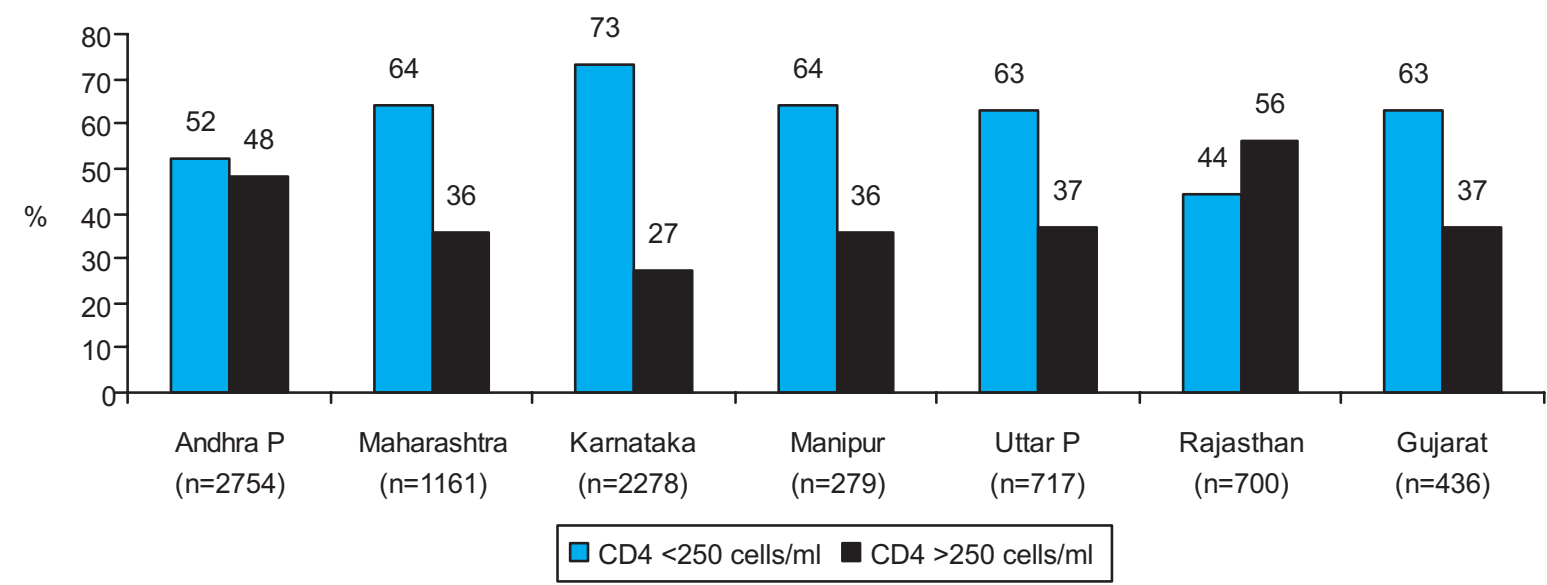

\subsection{Registration at ART centers}

Data collected from new registrations at ART centers revealed that almost two-thirds of newly diagnosed clients registered at the ART center within 1 month (30 days) and a further 11 per cent registered within three months. Thus the majority of clients reached ART centers within three months of their HIV test. Almost a fifth of all clients took more than six months to register at an ART center, of which 12 per cent took more than a year. Bivariate analysis shows that younger people; females; widowed or separated people; illiterate individuals or those with only a primary education; and unemployed persons were more likely to take longer to reach ART centers, and to register after two months (Table 5). 
Table 5: Time taken for registration at ART centers (ARTC)

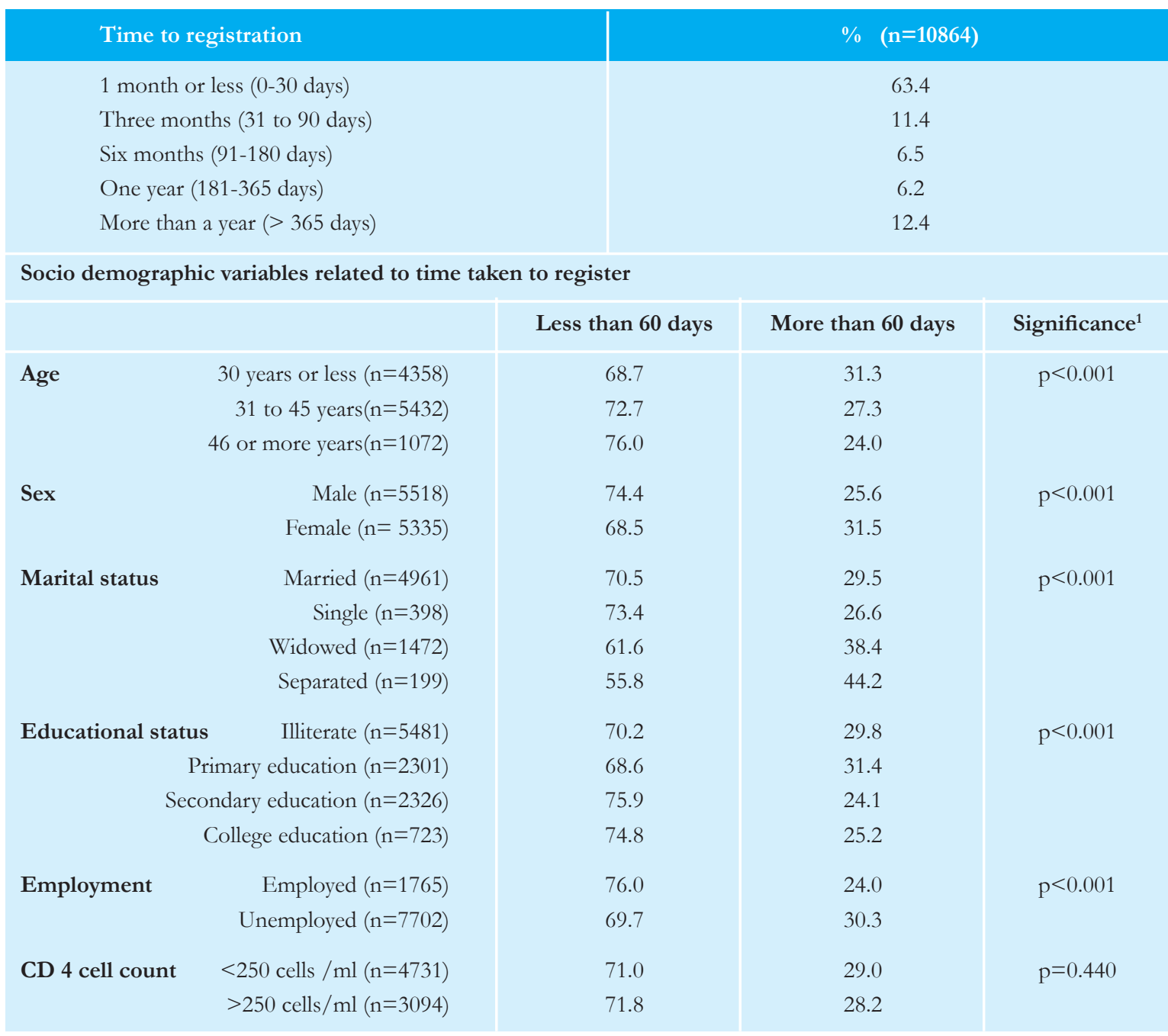

${ }^{1}$ Chi square test

\subsection{Comparison of clients from ICTCs and ART centers}

An objective of the study was to compare the sociodemographic characteristics of newly diagnosed HIV-positive people from ICTCs and ART centers to determine characteristics that identify clients who may not reach or register at ART centers. Comparisons were made by age, gender, education and marital status where data collected at ICTCs and ART centers were similarly coded (Figures 10-13). The age profile of HIV-positive clients $(\mathrm{n}=19310)$ at ICTC and ART centers showed minor differences between the two centers; the proportion of HIV-positive clients older than 30 years of age was marginally lower at ART centers. Differences were observed on the gender profile $(n=19310)$ : the proportion of males was lower at ART centers. On 
the educational profile $(\mathrm{n}=19183)$ the proportion of illiterate clients was higher at ART centers compared to all other educational categories. With regard to marital

Figure 10: Age profile of clients from ICTC and ART centres

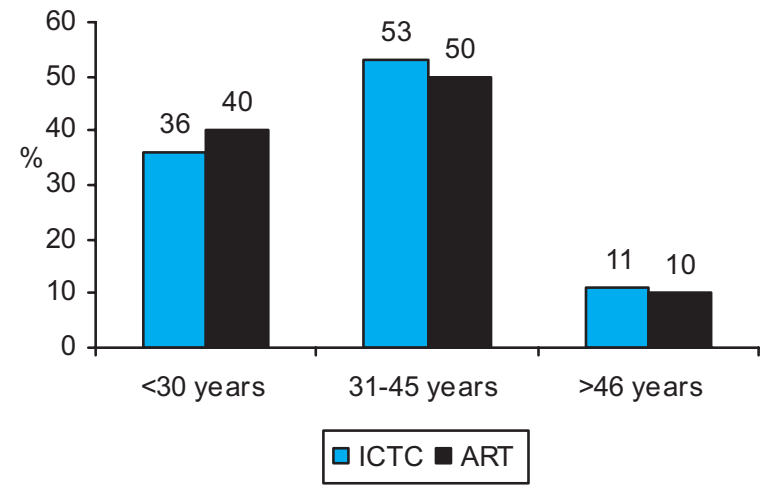

Figure 12: Educational level of clients from ICTC and ART centres

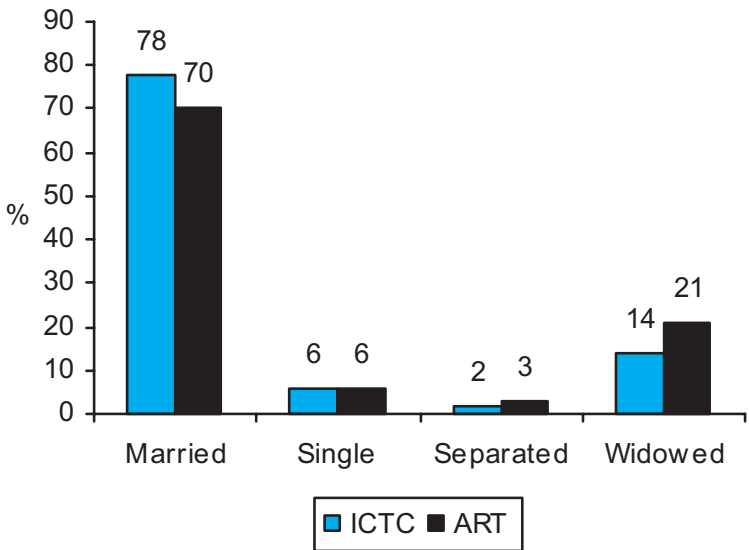

status, $(\mathrm{n}=15333)$ ART centers had a lower proportion of married clients but a higher proportion of widowed clients.

Figure 11: Gender profile of clients from ICTC and ART centres

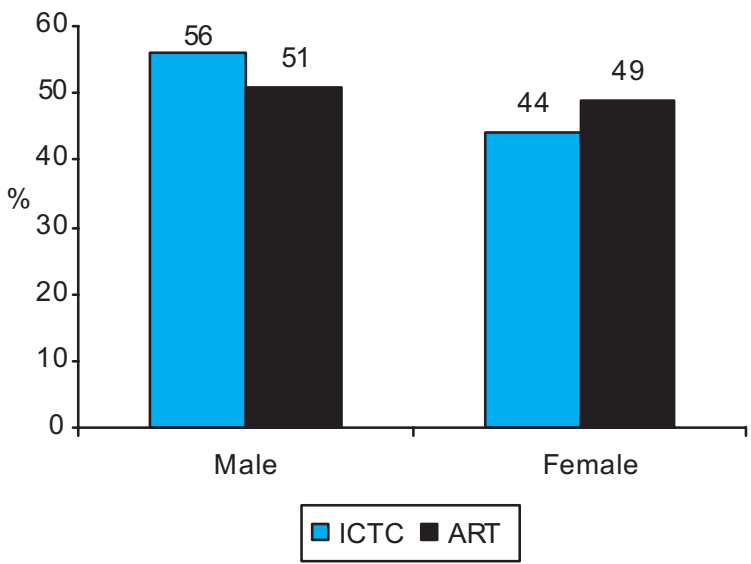

Figure 13: Marital status of clients from ICTC and ART centres

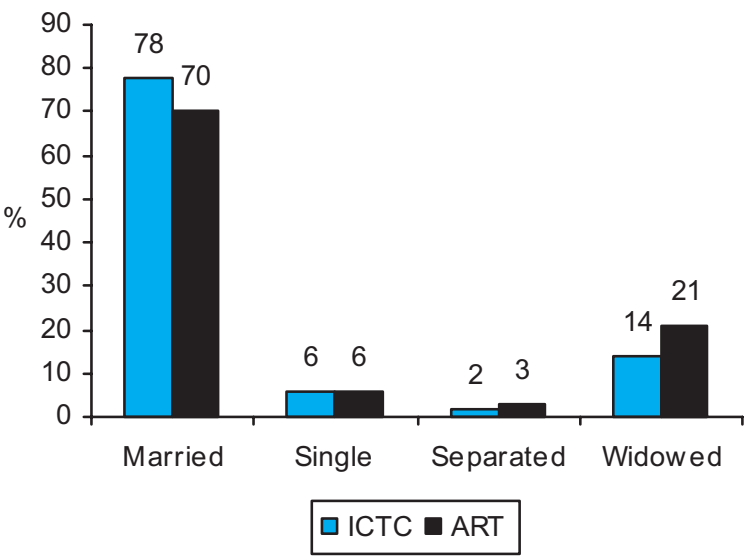




\subsection{Conclusions (Secondary data analysis)}

Information collected from ICTC and ART centers provides important insights into the HIV program of $\mathrm{NACO}$ and the profile of its clients.

Overall program services reach more men than women. However, important regional differences emerge indicating that women were under-represented to a larger extent in the low prevalence states. At both ICTCs and ARTCs, around three-fourths of HIVpositive clients were currently married and more than a tenth widowed. Women were less likely to be married and more likely to be widows at both ICTCs and ARTCs, highlighting their vulnerability. It is important to note that only half the spouses of HIV-positive married clients had been tested for HIV. At both ICTCs and ARTCs a substantial proportion of clients were illiterate (between 40-50 \%), there again women were more likely to be illiterate. At ICTCs more than half the newly diagnosed HIV-positive people were working as daily wage manual labour while at ARTCs more than three-quarters of newly registered clients were unemployed, highlighting the economic vulnerability of the population accessing public sector HIV services.

It is encouraging that 63 per cent of HIVpositive clients registered at ART centers within one month of their HIV test. However, the fact that 19 per cent of HIV-positive people registered at ART centers after six months or more of their HIV test including more than a tenth who registered after a year of their HIV test, requires evaluation. Further analysis of data collected from HIV-positive clients registering at ART centers suggests that younger people (less than 30 years of age), women, widowed or separated clients, clients with lower educational levels, and unemployed clients were more likely to register late at ART centers. Health care personnel at ICTCs would do well to focus on these sub-groups to provide additional support and counselling to assist these clients to reach ART centers for timely evaluation of eligibility for initiating treatment.

While information above obtained from clients registering at ART centers identifies groups at risk of registering late, the comparison of the socio-demographic characteristics of HIV-positive people from ICTC and ARTC provides important information on certain groups of HIV-positive individuals who may not access ART services. The proportion of HIVpositive men (while comparing data on gender), married (while comparing marital status) and older clients (while comparing age groups) was lower at ART centers compared to ICTCs suggesting that these groups may not be reaching ART centers. Similarly while comparing education, the proportion of clients with primary and higher education was lower at ART centers compared to ICTCs. It is important to understand that while there may be several factors that influence access to treatment, this comparison provides directions to the program on areas for further research.

The client load was variable across ICTCs and ART centers. ICTCs located in referral hospitals, where ART centers are located, have a substantially higher client load than other ICTCs. Similarly ART centers receive HIV-positive clients from several districts; and in low prevalence states from other states as well. High client load would impact the quality of service provided and the long distance travelled for 
out-of-district or out-of-state clients pose a barrier to accessing services. This may be especially relevant for the large proportion of HIV clients who were illiterate or clients working as daily wage labour or unemployed clients. Expanding the network by establishing ART Link centers in low prevalence states may serve to speed up enrolment.

A high client load also influences the quality of programmatic data collected. Data quality was variable across sites. There was substantial missing data on critical variables such as marital status, testing for spouses and HIV status of spouses at ICTCs and missing information on CD4 cell counts and family members at
ART centers. This impedes monitoring and programmatic evaluation. Closer monitoring of data quality is required and monitoring systems need strengthening. Further, on some variables, coding categories differed between ICTC and ART centers records preventing comparisons. Harmonisation of data collection at both points may be considered. Lastly, clients testing HIVpositive at ICTCs and clients registering at ART centers are presently not linked in any way apart from the date of HIV test and address of the ICTC; ART centers do not record PID numbers from ICTCs. This link would provide a measure of the proportion of HIV-positive clients from ICTCs who register at ART centers. 


\subsection{Cohort Study}

\subsection{Methods}

Study methods are described below.

\subsection{Study design}

A prospective observational cohort study design was used. Clients testing HIV-positive at government

ICTCs were recruited into the study and followed till they registered at ART centers in a two-month time frame.

All newly diagnosed HIV-positive people from selected ICTCs were invited to participate in the research study. Willing participants were interviewed immediately after their post-test counselling session. Participants were then followed and interviewed a second time when they registered at the referred ARTCs. Refusals were carefully documented.

Clients who did not register at ARTCs within two months after their HIV test and first interview at the ICTC were contacted in the community for an interview to ascertain reasons for not visiting or registering at the ARTC. Clients willing to undertake a face-to-face interview were invited to the ICTC or a place of their choice for the interview. Participants, who were not willing to participate in a face-to-face interview, underwent a telephone interview. Community health workers and PLHA network members working with or and engaged by the ICTCs helped to trace participants in the community. Careful documentation of the number of people contacted, people interviewed face-to-face, people interviewed by telephone and those not found was maintained.

\subsection{Study sites}

The cohort study was implemented in six states: Andhra Pradesh, Maharashtra, Karnataka, Rajasthan, Uttar Pradesh and Gujarat. In each of the three high HIV prevalence states two districts were included and within each district one ARTC and three high volume feeder ICTCs were included. In each of the three low HIV prevalence states one district with its main ARTC and three high volume ICTCs from outside the district (different districts) were included. Thus a total of 9 ART centers and 27 ICTCs were included in the cohort study.

\subsection{Study population and recruitment}

Newly diagnosed HIV-positive people undergoing post-test counselling were informed about the study by ICTC counsellors. Willing candidates were then approached by the study interviewer. Interviews were conducted after obtaining written informed consent from each participant. Informed consent was obtained twice; separately for the baseline interview and for the follow-up interview. Inclusion criteria for the study were: a) 18 years or more of age; b) HIV-positive test result; c) willingness to participate, to provide contact information and be contacted in the community; and d) residing at the same address for the past 6 months and not planning to move in the next three months (non-migrant).

Ethical approval for the study was obtained from the Institutional Review Board of the Population Council and from the Technical Resource Group on 
Research and Development, NACO and the NACO Ethics Committee for Research at NACO. Data collection instruments and informed consent forms were approved by both bodies.

\subsection{Data collection and management}

Data collection for the cohort study was done between September 2009 and March 2010. Baseline and follow-up interviews were conducted by trained research interviewers using semi-structured data collection instruments. Baseline interviews were conducted at ICTCs. Follow-up interviews were conducted at ARTCs for participants who registered at the clinic; for others who did not register follow-up interviews were done at mutually convenient locations such as participant's homes, ICTCs where they were tested, or NGO centers providing services for HIV-positive people.

Data collection instruments were transported to the Population Council office in Delhi and data were entered in a database using SPSS version 11.0. Quality checks were implemented to identify and rectify any discrepancies between the interview schedules and data base. Data was analysed at Population Council, Delhi.

\subsection{Limitations and challenges}

The research team faced several challenges during the data collection period due to political unrest and natural calamities. In Maharashtra a 5-week strike by ICTC staff in December 2009 impacted the number of tests undertaken and recruitment into the cohort. This was preceded by a month (August 2009) during which there was a shortage of HIV testing kits; kits were available only for emergency cases. During this period no HIV testing or limited testing took place and participants had to make multiple trips to obtain reports and receive referrals. In Andhra Pradesh recruitment went slow as a result of devastating floods in the project area in October 2009 and political disturbances in September 2009 and January 2010. In Gujarat, the ICTC at Palanpur was in the process of starting an ART center as a result of which some clients delayed registration so that they could register at the new ART center. 


\subsection{Results}

\subsection{Recruitment and retention of cohort}

Between September 1, 2009 and January 7, 2010 a total 1600 people tested positive at the 27 participating ICTCs. Of these $543 \mathrm{HIV}$-positive people were not included in the study: 79 (4.9\%) were children below 18 years of age and therefore ineligible; 191 $(11.9 \%)$ refused to be interviewed, $194(12.1 \%) \mathrm{did}$ not come back to the ICTC to collect their HIV test result; $14(0.8 \%)$ were too sick to be interviewed (seriously ill people/hospital admissions);

$63(3.9 \%)$ were not interviewed by study researchers for various reasons (e.g. counsellors did not inform HIV-positive people about the study, HIV-positive people could not wait for the interviews, strike by clinic staff, etc. ); one participant did not complete the interview and one participant was interviewed twice. Thus, a total of 1057 (66\%), newly diagnosed HIV-positive people participated in the study as part of the study cohort.

A total of 777 participants $(73.5 \%)$ from the baseline cohort registered at ARTCs within 2 months and were interviewed at their respective ARTCs. An additional 11 participants were interviewed at ARTCs, however, these 11 participants were not interviewed at baseline for reasons mentioned above and were excluded from the follow-up cohort.

Table 6: Recruitment and retention of the study cohort

\begin{tabular}{|c|c|c|c|}
\hline $\begin{array}{l}\text { Baseline cohort after } \\
\text { HIV test } \\
\text { (Interviewed at ICTC) }\end{array}$ & $\begin{array}{c}\text { Registered at ARTC } \\
<2 \text { months of HIV test } \\
\text { (Interviewed at ARTC) }\end{array}$ & $\begin{array}{c}\text { Not registered at ARTC } \\
\text { (Interviewed in the community) }\end{array}$ & $\begin{array}{l}\text { Lost to follow-up } \\
\text { (Not interviewed) }\end{array}$ \\
\hline $\mathrm{n}=1057$ & $73.5 \% \quad(n=777)$ & $17.9 \%(n=189)$ & $8.6 \%(n=91)$ \\
\hline
\end{tabular}

Of the baseline cohort $(n=1057) 280$ participants did not register at their referral ARTC within two months of their HIV test. Study researchers traced these participants in the community with assistance from ICTC counsellors and PLHIV network members linked to the ICTCs. Locator information was obtained from ICTC registers and study locator forms stored at ICTCs. The research team successfully contacted and interviewed

Figure 14: Retention of cohort by state

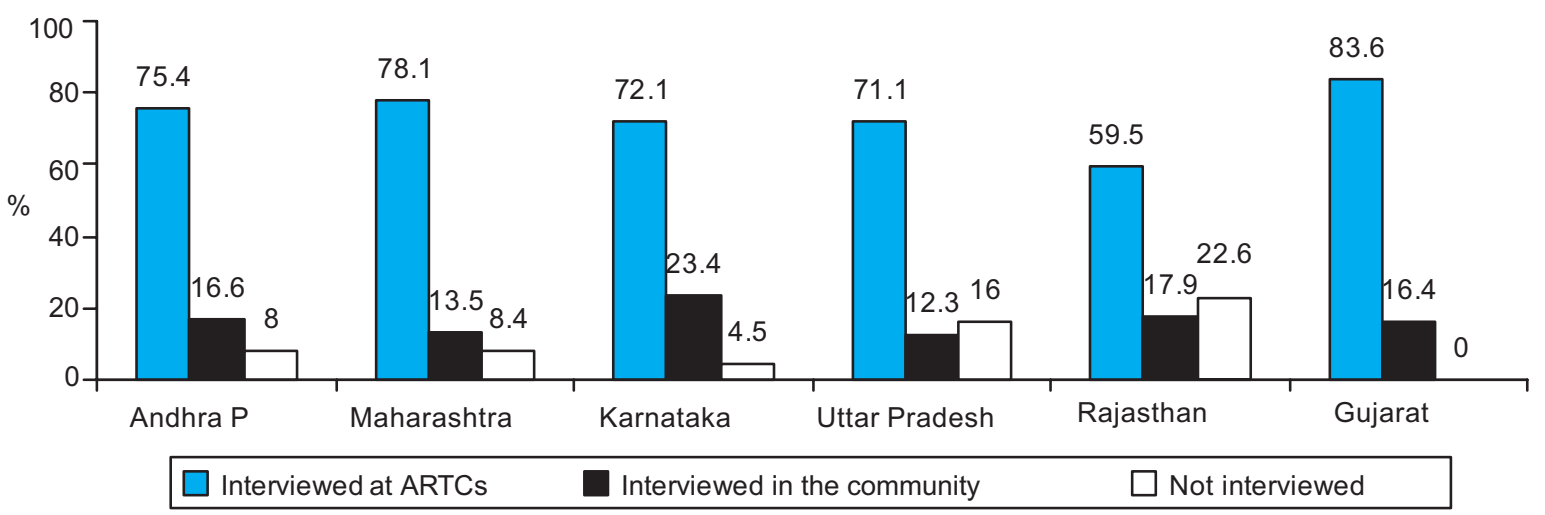


189 participants in the community (at their homes, at the ICTC where they were tested or at health centers). Thus a total of 966 participants were interviewed at follow up (777 at ARTCs and 189 in the community).

A total of 91 participants (8.6\%) could not be interviewed: 32 died within two months of their HIV test, 14 migrated out of the district, 5 refused to be interviewed, one participant moved to another ARTC, 8 participants were not available for interviews despite accurate locator information (not at home, not free) and 31 participants (3.4\%) could not be traced as they provided incorrect contact addresses and were considered lost to follow-up. Figure 14 shows the distribution of the proportion of clients who registered at ARTCs within 2 months, those who did not register and were interviewed in the community and those who were not interviewed. Uttar Pradesh and Rajasthan had the highest proportion of participants who were not interviewed. Table 7 shows the distribution of those who were not interviewed at follow-up. Thus the final sample of study participants included for analysis was 1057 participant interviews at baseline and 966 participants with follow-up interviews.

Table 7: Distribution of participants not interviewed at follow-up

\begin{tabular}{|l|c|c|c|c|c|c|c|}
\hline & $\begin{array}{c}\text { Andhra } \\
\text { Pradesh } \\
(\mathbf{n = 2 2})\end{array}$ & $\begin{array}{c}\text { Maharashtra } \\
(\mathrm{n}=\mathbf{1 3})\end{array}$ & $\begin{array}{c}\text { Karnataka } \\
(\mathrm{n}=\mathbf{1 5})\end{array}$ & $\begin{array}{c}\text { Uttar } \\
\text { Pradesh } \\
(\mathrm{n}=\mathbf{2 2})\end{array}$ & $\begin{array}{c}\text { Rajasthan } \\
(\mathbf{n}=\mathbf{1 6})\end{array}$ & $\begin{array}{c}\text { Gujarat } \\
(\mathbf{n}=\mathbf{0})\end{array}$ & $\begin{array}{c}\text { Total } \\
(\mathbf{n}=\mathbf{9 1})\end{array}$ \\
\hline Refused & 0 & 0 & 1 & 0 & 4 & 0 & 5 \\
\hline Died & 12 & 2 & 6 & 9 & 3 & 0 & 32 \\
\hline Migrated/moved out of district & 1 & 0 & 0 & 8 & 5 & 0 & 14 \\
\hline Address incorrect/untraced & 7 & 7 & 7 & 4 & 6 & 0 & 31 \\
\hline Registered elsewhere & 0 & 0 & 0 & 1 & 0 & 0 & 1 \\
\hline Not available for interview & 2 & 4 & 1 & 0 & 1 & 0 & 8
\end{tabular}

\subsection{Profile of study participants}

\subsubsection{Socio-demographic profile of study participants}

Table 8 provides information on the demographic profile of study participants by state. Overall 51.7 per cent $(n=546)$ of the participants were female. The gender distribution varied across states. In Gujarat and Rajasthan women constituted a smaller majority at 34.3 per cent and 40.5 per cent respectively.

Maharashtra had the highest proportion of women participants at 60.6 per cent.
The mean age for all clients was 34.7 years (SD 8.9) and the median age 35 years (IQR: 29, 40). Males were marginally older than female clients. The mean age for males was 36 years, SD 8.9 and females was 33.4 years, SD 8.7 ( $p<0.001 \mathrm{~T}$ test). Age ranged between 18 to 70 years for both males and females. More than a third $(38.8 \%)$ of the participants were under 30 years of age; in Karnataka nearly half were under 30 years. A tenth of the clients were over 45 years of age (Table 8). Interestingly, 14 participants were over 60 years of age.

Across all states the majority of clients were married $(65.3 \%)$. Rajasthan had the highest proportion of 
married participants at 77.4 per cent (Table 8). Over a fifth of clients reported being widowed (21.7\%). Men were more likely to be married compared to female participants (m: $80 \%$ vs. f: 51.5\%; p < 0.001). More female participants reported being widowed compared to male participants (f: $34.8 \%$ vs. m: $7.6 \%$; $<0.001$ ). Among married participants, 44 per cent of the participants had spouses who had not yet tested for HIV (m: 48.2\% vs. f: $37.3 \%)$. Of those tested, women were more likely to report a HIV-positive spouse (f: $49.8 \%$ vs. m: $27.8 \%$; $\mathrm{p}<0.001)$. Death of a spouse due to HIV was reported by 58.6 per cent of all widowed participants; female participants were more likely to report death of the spouse due to HIV (f: $64.6 \%$ vs. m: $30.8 \%$; p < 0.001).
Overall, 56.2 per cent of participants across all states were illiterate, 15 per cent had a primary education and 28 per cent had secondary or higher education. Maharashtra had the highest proportion of participants with secondary or higher education $(52.9 \%)$ while Karnataka had the highest proportion of illiterate participants.

The majority of participants were Hindu (Table 8). Almost two-thirds of all participants lived with their spouse and/or children $(65.9 \% ; \mathrm{n}=695)$ and their extended family $(23.7 \% ; \mathrm{n}=250)$. Almost a tenth lived alone $(9.9 \% ; \mathrm{n}=104)$ and less than one per cent shared living quarters with room-mates or friends or co-workers [data not shown].

Table 8: Socio-demographic profile of study participants by state

\begin{tabular}{|c|c|c|c|c|c|c|c|c|}
\hline & & $\begin{array}{c}\text { Andhra } \\
\text { Pradesh } \\
\%(n=276)\end{array}$ & $\begin{array}{l}\text { Maharashtra } \\
\%(n=155)\end{array}$ & $\begin{array}{l}\text { Karnataka } \\
\%(n=337)\end{array}$ & $\begin{array}{c}\text { Uttar } \\
\text { Pradesh } \\
\%(n=138)\end{array}$ & $\begin{array}{l}\text { Rajasthan } \\
\%(n=84)\end{array}$ & $\begin{array}{l}\text { Gujarat } \\
\%(n=67)\end{array}$ & $\begin{array}{c}\text { Total } \\
\%(n=1057)\end{array}$ \\
\hline \multirow[t]{2}{*}{ Gender } & Males & $49.6(137)$ & $39.4(61)$ & $45.1(152)$ & $48.6(67)$ & $59.5(50)$ & $65.7(44)$ & $48.3(511)$ \\
\hline & Females & $50.4(139)$ & $60.6(94)$ & $54.9(185)$ & $51.4(71)$ & $40.5(34)$ & $34.3(23)$ & $51.7(546)$ \\
\hline \multirow[t]{3}{*}{ Age } & $\leq 30 \mathrm{yrs}$ & $40.2(111)$ & $27.7(43)$ & $48.1(162)$ & $29.7(41)$ & $32.1(27)$ & $38.9(26)$ & $38.8(410)$ \\
\hline & $31-45$ yrs & $48.2(133)$ & $60.0(93)$ & $43.0(145)$ & $64.5(89)$ & $54.8(46)$ & $50.7(34)$ & $51.1(540)$ \\
\hline & $\geq 46$ yrs & $11.6(32)$ & 12.3(19) & $8.9(30)$ & $5.8(8)$ & 13.1(11) & $10.4(7)$ & 10.1(107) \\
\hline \multicolumn{9}{|c|}{ Marital status } \\
\hline \multicolumn{2}{|c|}{ Currently married } & $62.7(173)$ & $60.6(94)$ & $66.5(224)$ & $66.7(92)$ & $77.4(65)$ & $62.7(42)$ & $65.3(690)$ \\
\hline \multicolumn{2}{|c|}{ Living together, not married } & $1.8(5)$ & $0.6(1)$ & $1.7(6)$ & $0.7(1)$ & $0.0(0)$ & $0.0(0)$ & $1.2(13)$ \\
\hline & Single & $4.3(12)$ & $8.4(13)$ & $9.5(32)$ & $0.7(1)$ & $4.7(4)$ & $14.9(10)$ & $6.8(72)$ \\
\hline \multicolumn{2}{|c|}{ Divorced/separated } & $8.7(24)$ & $8.4(13)$ & $3.3(11)$ & $0.7(1)$ & $1.2(1)$ & $4.5(3)$ & $5.0(53)$ \\
\hline & Widowed & $22.5(62)$ & $22(34)$ & $19.0(64)$ & $31.2(43)$ & $16.7(14)$ & $17.9(12)$ & $21.7(229)$ \\
\hline \multirow[t]{2}{*}{ Education } & Illiterate & $55.1(152)$ & $27.1(42)$ & $75.7(255)$ & $52.2(72)$ & $53.5(45)$ & $41.8(28)$ & $56.2(594)$ \\
\hline & Primary & $19.2(53)$ & $20.0(31)$ & $9.5(32)$ & $14.5(20)$ & $15.5(13)$ & $20.9(14)$ & $15.4(163)$ \\
\hline \multicolumn{2}{|c|}{ Secondary or higher } & $25.7(71)$ & $52.9(82)$ & $14.8(50)$ & $33.3(46)$ & $31.0(26)$ & $37.3(25)$ & $28.4(300)$ \\
\hline \multirow[t]{4}{*}{ Religion } & Hindu & $72.5(200)$ & $90.3(140)$ & $96.1(324)$ & $99.3(137)$ & $91.7(77)$ & $91.0(61)$ & 88.8(939) \\
\hline & Muslim & $2.5(7)$ & $4.5(7)$ & $3.6(12)$ & $0.7(1)$ & $7.1(6)$ & $7.5(5)$ & $3.6(38)$ \\
\hline & Christians & $25.0(69)$ & $0.0(0)$ & $0.0(0)$ & $0.0(0)$ & $0.0(0)$ & $1.5(1)$ & $6.6(70)$ \\
\hline & Other & $0.0(0)$ & $5.2(8)$ & $0.3(1)$ & $0.0(0)$ & $1.2(1)$ & $0.0(0)$ & $1.0(10)$ \\
\hline
\end{tabular}




\subsubsection{Employment and income}

Across all states more than three-fourths $(78.8 \%$, $n=833$ ) of participants were employed. However, employment status varied across states (Table 9). Andhra Pradesh had the highest proportion of unemployed participants $(32.2 \%)$. Overall men were more likely to be employed compared to female participants (m: 87.3\% vs. f: $70.9 \%$; $<0.001)$. The main reason provided for not working was: (i) being too sick: 39.5 per cent; (ii) not wanting to work: 29 per cent; (iii) never worked: 21.8 per cent; (iv) lost job due to HIV: 1 per cent; and (v) other reasons: 8.6 per cent. More female participants reported never having worked (f: $28.2 \%$ vs. m: $6.3 \%$ ) and not wanting to work (f: $38.4 \%$ vs. m: $6.2 \%$ ); while more male participants reported not working due to illness (m: $79.7 \%$ vs. f: $23.1 \%$ ).

Two-thirds (68\%) of employed participants were working as agricultural or other manual labour. Threequarters of the participants were working in their residential villages (Table 9). Uttar Pradesh and Rajasthan had the highest proportion of employed participants who worked outside their residential district $40 \%$ and $28 \%$ respectively). The study participant was the main earning member for half the families (52\%); of those male participants were the main earning member in most households (69\%). Self-reported median household income for all states was Rs 2000 (IQR: 1350-3000); there were no significant differences between states.

Table 9: Employment and income profile of study participants

\begin{tabular}{|c|c|c|c|c|c|c|c|}
\hline & $\begin{array}{c}\text { Andhra } \\
\text { Pradesh } \\
\%(n=276)\end{array}$ & $\begin{array}{c}\text { Maharashtra } \\
\%(n=155)\end{array}$ & $\begin{array}{l}\text { Karnataka } \\
\%(n=337)\end{array}$ & $\begin{array}{c}\text { Uttar } \\
\text { Pradesh } \\
\%(n=138)\end{array}$ & $\begin{array}{l}\text { Rajasthan } \\
\%(n=84)\end{array}$ & $\begin{array}{l}\text { Gujarat } \\
\%(n=67)\end{array}$ & $\begin{array}{c}\text { Total } \\
\%(n=1057)\end{array}$ \\
\hline Employment Employed & $67.8(187)$ & $82.6(128)$ & $84.6(285)$ & $84.8(117)$ & $73.8(62)$ & $80.6(54)$ & $78.8(833)$ \\
\hline Unemployed & $32.2(89)$ & $17.4(27)$ & $15.4(52)$ & $15.2(21)$ & $26.2(22)$ & $19.4(13)$ & $21.2(224)$ \\
\hline Location of workplace & $(n=173)$ & $(n=127)$ & $(n=282)$ & $(n=684)$ & $(n=575)$ & $(n=547)$ & $(n=771)^{1}$ \\
\hline Same village & $63.4(116)$ & $82.7(105)$ & $89.4(252)$ & $4.1(30)$ & $4.4(31)$ & $9.6(43)$ & $74.8(577)$ \\
\hline Within district & $26.2(48)$ & $12.6(16)$ & $7.8(22)$ & $16.2(11)$ & $17.5(10)$ & $13.0(7)$ & $14.8(114)$ \\
\hline Outside district & $10.4(9)$ & $4.7(6)$ & $2.8(8)$ & $39.7(27)$ & $28.1(16)$ & $7.4(4)$ & $10.4(80)$ \\
\hline Main earning & $(n=275)$ & $(n=155)$ & $(n=336)$ & $(n=137)$ & $(n=84)$ & $(n=67)$ & $(n=1057)^{2}$ \\
\hline member & $55.6(153)$ & $60.0(93)$ & $43.2(145)$ & $45.3(62)$ & $60.7(51)$ & $65.7(44)$ & $51.9(548)$ \\
\hline Males & $74.6(114)$ & $52.6(49)$ & $61.3(89)$ & $79.0(49)$ & $80.3(41)$ & $81.8(36)$ & $68.9(378)$ \\
\hline Females & $25.4(39)$ & $47.4(44)$ & $38.7(56)$ & $21.0(13)$ & $19.7(10)$ & $18.2(8)$ & $31.1(170)$ \\
\hline Spouse & $24.8(68)$ & $22.6(35)$ & $35.4(119)$ & $21.9(30)$ & $29.8(25)$ & $20.8(14)$ & $27.6(291)$ \\
\hline Parents & $7.6(21)$ & $6.5(10)$ & $9.8(33)$ & $16.8(23)$ & $3.6(3)$ & $9.0(6)$ & $9.2(96)$ \\
\hline Siblings & $1.5(4)$ & $3.9(6)$ & $6.3(21)$ & $3.6(5)$ & $1.2(1)$ & - & $3.5(37)$ \\
\hline Others & $10.5(29)$ & $7.0(11)$ & $5.3(18)$ & $12.4(17)$ & $4.7(4)$ & $4.5(3)$ & $7.8(82)$ \\
\hline Household monthly & $(n=275)$ & $(n=155)$ & $(n=322)$ & $(n=138)$ & $(n=84)$ & $(n=67)$ & $(n=1040)^{2}$ \\
\hline income & Rs. 3000 & Rs. 2500 & Rs. 1500 & Rs. 1500 & Rs. 3000 & Rs. 2500 & Rs 2000 \\
\hline Median (IQR) & $(2000-4000)$ & $(1500-4000)$ & $(1000-3000)$ & $(1000-3000)$ & $(2000-4000)$ & $(1500-3000)$ & $(1350-3000)$ \\
\hline
\end{tabular}




\subsubsection{Poverty}

The Quick Poverty Score (QPS) India was used to assess the economic status of study participants. The QPS is a simple, easy-to-use tool that health service programs can use to assess the prevalence of poverty among their clients. The QPS provides a snapshot of uptake of program services by those living below the national poverty line and below US \$1 per day. The index utilizes 10 questions on housing conditions, household assets and household amenities to form a score that is used to provide the distribution of the study population against probability scores of falling below the national poverty line and below US $\$ 1 /$ day. Questions are listed in Annex 1. Data for the QPS was collected only at the follow-up interview and is available only for participants who were interviewed at ART centers or in the community $(n=966)$.

Table 10: Quick Poverty Score card for study participants

\begin{tabular}{|c|c|c|c|c|c|c|c|c|}
\hline $\begin{array}{l}\text { National } \\
\text { poverty } \\
\text { likelihoods } \\
(\%)\end{array}$ & $\begin{array}{l}\text { Likelihood } \\
\text { of falling } \\
\text { below US } \\
\$ 1 / \text { day }(\%)\end{array}$ & $\begin{array}{c}\text { Andhra } \\
\text { Pradesh } \\
\% \\
(n=254)\end{array}$ & $\begin{array}{c}\text { Maharashtra } \\
\begin{array}{c}\% \\
(n=142)\end{array}\end{array}$ & $\begin{array}{c}\text { Karnataka } \\
\begin{array}{c}\% \\
(\mathrm{n}=322)\end{array}\end{array}$ & $\begin{array}{c}\text { Uttar } \\
\text { Pradesh } \\
\% \\
(n=116)\end{array}$ & $\begin{array}{c}\text { Rajasthan } \\
\begin{array}{c}\% \\
(\mathrm{n}=65)\end{array}\end{array}$ & $\begin{array}{c}\text { Gujarat } \\
\\
\% \\
(n=65)\end{array}$ & $\begin{array}{c}\text { Total } \\
\\
\% \\
(n=964)^{1}\end{array}$ \\
\hline National 62.4 & 81.9 & - & - & - & - & - & - & - \\
\hline National 43.2 & 63.1 & $0.4(1)$ & $0.7(1)$ & $5.2(16)$ & $34.8(32)$ & $2.5(1)$ & $3.8(2)$ & $6.1(53)$ \\
\hline National 24.4 & 44.1 & $6.9(16)$ & $3.6(5)$ & $16.9(52)$ & $25.0(23)$ & $22.5(9)$ & $3.8(2)$ & $12.4(107)$ \\
\hline National 16.8 & 26.3 & $14.3(33)$ & $15.9(22)$ & $26.0(80)$ & $21.7(20)$ & $17.5(7)$ & $11.3(6)$ & $19.5(168)$ \\
\hline National 7.8 & 11.2 & $25.1(58)$ & $18.1(25)$ & $25.3(78)$ & $10.9(10)$ & $27.5(11)$ & $18.9(10)$ & $22.3(192)$ \\
\hline National 5.4 & 4.1 & $20.8(48)$ & $17.4(24)$ & $15.9(49)$ & $7.6(7)$ & $20.0(8)$ & $30.2(16)$ & $17.6(152)$ \\
\hline National 4.9 & 2.1 & $16.9(39)$ & $23.2(32)$ & $6.8(21)$ & - & $2.5(1)$ & $5.7(3)$ & $11.1(96)$ \\
\hline National 1.6 & 0.7 & $10.8(25)$ & $14.5(20)$ & $2.9(9)$ & - & - & $17.0(9)$ & $7.3(63)$ \\
\hline National 0.9 & 0.1 & $3.5(8)$ & $5.1(7)$ & $1.0(3)$ & - & $5.0(2)$ & $9.4(5)$ & $2.9(25)$ \\
\hline National 0.0 & 0.0 & $1.3(3)$ & $1.4(2)$ & - & - & $2.5(1)$ & - & $0.7(6)$ \\
\hline
\end{tabular}

Note: Column 1 and 2 refer to the Quick Poverty Score for India. See reference for details on calculation.

Table 10 provides the distribution of the scores by state. Overall 38 per cent of the participants fell into the categories with higher probability of falling Below Poverty Line (BPL): 6 per cent with 43.2 per cent likelihood of being BPL (63.1\% likelihood of being $<\$ 1 /$ day), 12.4 per cent with 24.4 per cent likelihood of being BPL (44.1\% likelihood of being < $\$ 1 /$ day) and 19.5 per cent with 16.8 per cent likelihood of being BPL (26.3\% likelihood of being $<\$ 1 /$ day). Twenty-two per cent of all participants belonged to categories with less than 5 per cent probability of being BPL (last four categories).

In Uttar Pradesh, participants were distributed in categories with higher probability of being BPL; 
34.8 per cent of the participants were placed in the category with 43.2 per cent likelihood of being BPL $(63.1 \%$ likelihood of being $<\$ 1 /$ day). By contrast in Maharashtra and Andhra Pradesh the distribution edged toward lower likelihood of being BPL with 0.7 per cent per cent and 0.4 per cent respectively with 43.2 per cent likelihood of being BPL.

\subsection{HIV testing}

\subsubsection{Referrals}

During their interviews at the ICTC, participants were asked about how they had been referred. The majority $(41 \%)$ had been referred from government sector facilities. These included referrals made by Auxiliary Nurse and Midwives (ANMs), Accredited Social Health Activists (ASHAs) and Anganwadi workers $(5.9 \% ; n=62)$. Self referrals constituted almost a fifth of the referrals (19\%), largely taking place in the low HIV prevalence states (Table 11). Referrals from the private sector were highest in UP, Gujarat and Andhra Pradesh. In Karnataka more than half of the referrals and in Rajasthan more than two-thirds of the referrals were from government facilities. Almost a tenth $(11.5 \%)$ of the participants were referred to the ICTC by family members, relatives and friends; the highest proportion in Andhra Pradesh.

Table 11: Participant referral to ICTCs by state

\begin{tabular}{|l|c|c|c|c|c|c|c|}
\hline & $\begin{array}{c}\text { Andhra } \\
\text { Pradesh } \\
\%(\mathrm{n}=\mathbf{2 7 6})\end{array}$ & Maharashtra & Karnataka & $\begin{array}{c}\text { Uttar } \\
\text { Pradesh }\end{array}$ & Rajasthan & Gujarat & Total \\
\hline Government sector & $31.9(88)$ & $40.7(63)$ & $50.8(171)$ & $23.9(33)$ & $66.7(56)$ & $31.4(21)$ & $40.9(432)$ \\
\hline Private sector & $23.9(66)$ & $18.7(29)$ & $8.9(30)$ & $23.9(33)$ & $2.4(2)$ & $26.8(18)$ & $16.9(178)$ \\
Self referral & $16.3(45)$ & $11.0(17)$ & $22.6(76)$ & $20.3(28)$ & $21.4(18)$ & $22.4(15)$ & $18.8(199)$ \\
\hline Relatives and friends & $19.2(53)$ & $14.8(23)$ & $5.7(19)$ & $12.3(17)$ & $2.4(2)$ & $10.4(7)$ & $11.5(121)$ \\
\hline NGO & $8.7(24)$ & $14.8(23)$ & $120(40)$ & $19.6(27)$ & $7.1(6)$ & $9.0(6)$ & $11.9(126)$ \\
\hline
\end{tabular}

Note: Private sector includes private doctors, RMP, hospitals, laboratories. Government sector includes government hospitals, PHC, CHCs, TB program.

\subsubsection{Reasons for undertaking HIV test}

Participants were asked about their reason(s) for seeking a HIV test at the ICTC. Multiple responses were allowed (Table 12). The most frequently cited reason for seeking a HIV test across all states was frequent illness (68\%). Almost a fifth said they requested a HIV test because of their own risky sexual behaviour while, a fifth requested it after their spouse or partner tested HIV-positive, and just over a tenth did so after the death of their spouse or intimate partner. More female participants reported undertaking a test after the death of a spouse than male participants (f: $20.9 \%$ vs. m: $2.2 \%$; p < 0.001). Interestingly, just over a fifth of the participants also 
reported undertaking HIV test on their partner's request or because of their partner's high risk behaviour. More female participants reported testing for HIV due to their partner's high risk behaviour than males (m: 17.4\% vs. f: $2.4 \%$; $<0.001)$ ). Overall 13.4 per cent of participants reported testing at the ICTC to confirm a previous positive result.

\section{Number of HIV tests}

Although two-thirds of the participants reported only one HIV test including the current test $(67.8 \%$; $=712)$, multiple testing was commonly reported. Overall more than a quarter $(26.5 \% ; \mathrm{n}=278)$ reported two HIV tests, 4.3 per cent $(n=45)$ reported three tests and 1.6 per cent $(\mathrm{n}=16)$ reported four or more tests. Figure 15 shows the distribution by state. Around a third of the participants in UP, Gujarat, Maharashtra and Andhra had come in for second HIV tests.

Among those who had two or more tests, the median duration of time since the first HIV test was 6.5 months (IQR: 2, 24). Significantly more men reported multiple tests than female participants. Nearly

Table 12: Reasons for seeking HIV testing at ICTCs

\begin{tabular}{|c|c|c|c|c|c|c|c|}
\hline & $\begin{array}{c}\text { Andhra } \\
\text { Pradesh } \\
\%(n=276)\end{array}$ & $\begin{array}{c}\text { Maharashtra } \\
\%(n=141)^{5}\end{array}$ & $\begin{array}{l}\text { Karnataka } \\
\%(n=336)\end{array}$ & $\begin{array}{c}\text { Uttar } \\
\text { Pradesh } \\
\%(n=138)\end{array}$ & $\begin{array}{l}\text { Rajasthan } \\
\%(n=84)\end{array}$ & $\begin{array}{l}\text { Gujarat } \\
\%(n=67)\end{array}$ & $\begin{array}{c}\text { Total }^{1} \\
\%(n=1042)\end{array}$ \\
\hline Frequent illness & $73.2(202)$ & $57.4(89)$ & $75.9(255)$ & $68.8(95)$ & $54.8(46)$ & $52.2(35)$ & $68.4(722)$ \\
\hline Partner HIV-positive & $21.4(59)$ & $23.2(36)$ & $13.7(46)$ & $20.3(28)$ & $27.4(23)$ & $19.4(13)$ & $20.0(211)$ \\
\hline Wanted a second opinion & $20.7(57)$ & $18.1(28)$ & $8.0(27)$ & $2.9(4)$ & $10.7(9)$ & $23.9(16)$ & $13.4(141)$ \\
\hline $\begin{array}{l}\text { Own risky behaviour/ } \\
\text { unprotected sex }\end{array}$ & $13.8(38)$ & $24.5(38)$ & 27.4(92) & $3.6(5)$ & 21.4(18) & 22.4(15) & $19.7(206)$ \\
\hline Partner's behaviour/request & $18.1(50)$ & $33.9(37)$ & $27.4(92)$ & $10.2(14)$ & $26.2(22)$ & $9.0(6)$ & $21.2(221)$ \\
\hline $\begin{array}{l}\text { Death of spouse/partner } \\
\text { Family member }\end{array}$ & $11.3(113)$ & $14.8(23)$ & $9.8(330$ & $18.1(25)$ & $13.1(11)$ & $3.0(2)$ & $11.8(125)$ \\
\hline HIV-positive/death ${ }^{2}$ & $3.6(10)$ & $14.9(23)$ & $2.7(9)$ & $2.1(3)$ & $4.8(4)$ & $1.5(1)$ & $4.7(50)$ \\
\hline Exposure to blood ${ }^{3}$ & $9.0(25)$ & $22.6(35)$ & $2.7(9)$ & $0.7(1)$ & $2.4(2)$ & $12.0(8)$ & $7.6(80)$ \\
\hline Others $^{4}$ & $29.3(81)$ & $21.3(30)$ & $9.5(32)$ & $22.5(31)$ & $11.9(10)$ & $37.3(25)$ & $20.1(209)$ \\
\hline
\end{tabular}

${ }^{1}$ Multiple responses possible; total may not add up to $100 \%$

${ }^{2}$ Includes death of a child

${ }^{3}$ Includes work related exposure, blood transfusion, fear of unsafe injections and injecting drug use

${ }^{4}$ Includes pregnancy, accidents/injuries, medical/dental checkups, blood donation, because of access to free ART and

${ }^{5} 15$ cases with missing information from Maharashtra 
Figure 15: Number of HIV tests undertaken by study participants by state (including current HIV test)

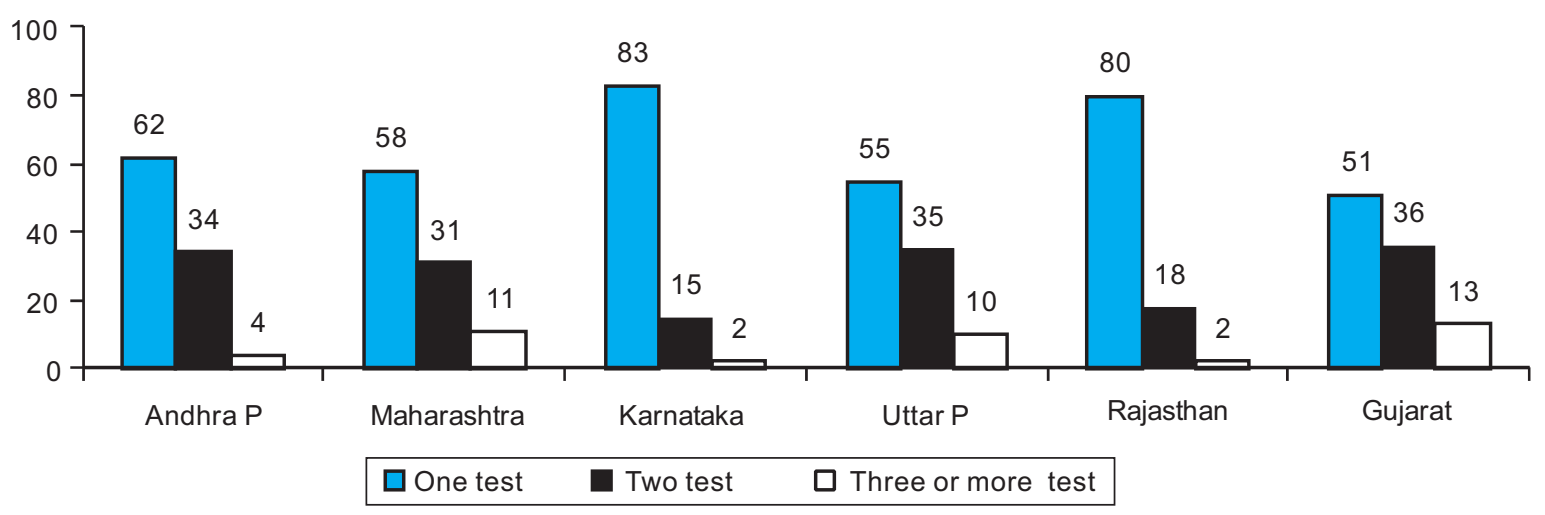

a third of male participants reported having undertaken two HIV tests: (m: $30.7 \%$ vs. f: $22.5 \%$; $\mathrm{p}<0.001)$ and less than a tenth reported three or more tests (m: $7.5 \%$ vs. f: $4.2 \% ; \mathrm{p}<0.001$ ). Among those who came in for a repeat HIV test, 75.8 per cent of participants reported that their first HIV test was done in the private sector. In the high HIV prevalence states the proportion of participants testing in the private sector was higher (Andhra Pradesh: 74.8\%; Maharashtra: 83.1\%; Karnataka: 86.5\%) than in the low HIV prevalence states (Rajasthan: 41.2\% and Gujarat: $60.6 \%$ ) with the exception of Uttar Pradesh: 77.6 per cent.

\subsubsection{HIV testing and counselling services}

\section{Number of visits made to the ICTC}

The majority of participants reported a single visit to the ICTC for their HIV test $(92 \%, \mathrm{n}=974)$. Around
4 per cent $(n=42)$ participants reported a second visit and 2 per cent $(n=20)$ reported three or more visits. The main reasons for repeat visits were the absence of the counsellor $(n=23)$ mostly reported from Andhra Pradesh ( $\mathrm{n}=15)$; lack of testing kits ( $\mathrm{n}=16$; almost all reported from Maharashtra); reaching the center after working hours $(\mathrm{n}=8)$; and non-availability of the lab technician $(\mathrm{n}=3)$. Twelve participants provided no reason $(n=12)$.

Although attempts are made to provide HIV results the same day in the evening at most ICTCs, more than a tenth of the participants reported having to undertake multiple visits for collecting test results $(13.2 \% ; \mathrm{n}=138)$. Thirty per cent of participants in Andhra Pradesh ( $\mathrm{n}=39), 16.1$ per cent in Maharashtra and 9.8 per cent in UP reported multiple visits to collect their test results. The main reasons cited for these visits were the absence of the counsellor $(13.2 \% ; \mathrm{n}=16)$; test results not ready/ 
available $(26.1 \%$; $\mathrm{n}=36)$; counsellors asking HIVpositive clients to first visit the TB department for a chest $\mathrm{x}$-ray $(28.2 \% ; \mathrm{n}=39)$; reaching the clinic after working hours $(14.9 \% ; \mathrm{n}=18)$; having to meet the doctor $(3.3 \% ; \mathrm{n}=4)$ and other reasons $(5.7 \% ; \mathrm{n}=8)$. In Andhra Pradesh counsellors asked participants to visit the TB department and obtain chest $\mathrm{x}$-rays prior to releasing their HIV test result.

\section{Waiting time at ICTCs}

Overall, the majority of participants $(84.8 \%)$ waited less than 30 minutes to see the counsellor. Over 90 per cent of participants were seen within 30 minutes in Gujarat (95.5\%), Karnataka (94.6\%), Rajasthan (93.9\%), and Uttar Pradesh (93.3\%). The proportion of participants seen within 30 minutes was lower in Andhra Pradesh (74.3\%) and lowest in Maharashtra $(65.3 \%)$. Counsellors spent a median of 10 minutes (IQR: 5, 15) with participants to provide pre-test counselling and a median of 20 minutes (IQR: 15, 30) for post-test counselling. Counselling sessions went on for up to an hour in a few cases.

\section{Pre-test Counselling}

Participants were asked several questions to assess the quality of the counselling they received at ICTCs. These interviews were conducted immediately after the post-test counselling after the participants received their HIV-positive results; therefore, recall is expected to be good. Table 13 shows the distribution of participant responses by state. The quality of counselling was variable across the states.

During pre-test counselling only 70 per cent of participants were told about how the HIV test works and only 36 per cent of participants were told about the window period (Table 13). Routes of HIV transmission were discussed with 80 per cent of the participants and prevention of transmission with 78 per cent of participants. Only 62 per cent participants reported that they were able to ask questions. Confidentiality of the results was mentioned to less than three-fourths of participants.

\section{Post-test counselling}

During post-test counselling the majority of participants were told about the meaning of the test result (Table 14). However, testing of sexual partners was mentioned to 72 per cent of participants and testing of children to 67 per cent of participants. Although ways to prevent HIV were discussed with 88 per cent of participants, condom demonstration was reported by only just over half the participants.

With regard to ART services the majority of participants received an explanation on antiretroviral therapy $(86.5 \%)$, were provided referral slips for ART centers $(86.5 \%)$ and given information on the availability of free ART (91.5\%). Directions to the nearest ART center were provided to around three-fourths of 
Table 13: Topics covered by counsellors during pre-test counselling

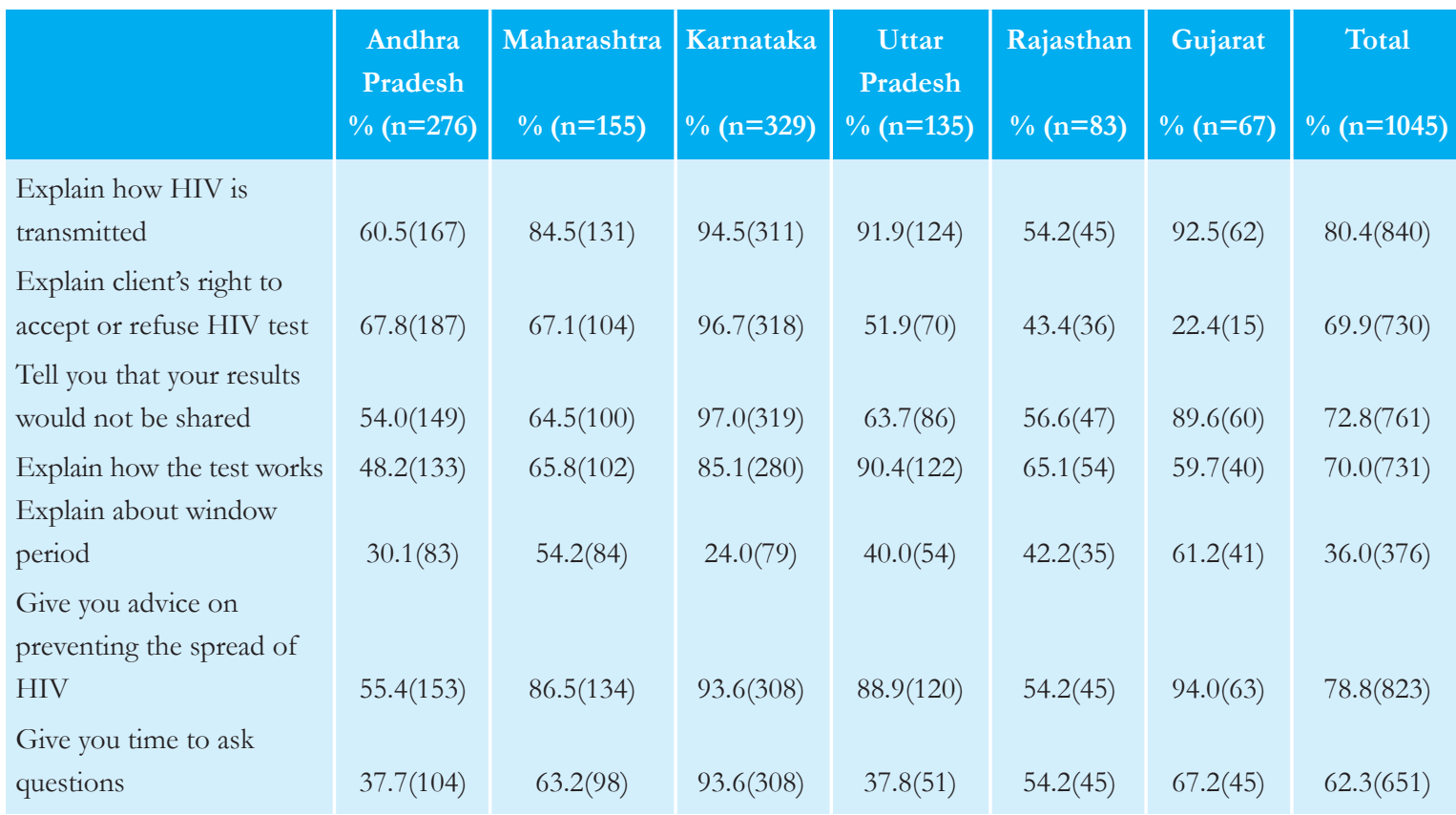

Note: All respondents were asked all options.

participants. CD4 testing to determine eligibility for initiating treatment was discussed with just over threefourths of participants (Table 14).

Travel concessions for PLHIV are available in some states, especially in the three low prevalence states; the availability of travel concessions was mentioned to just over a third of participants overall. In Rajasthan and Karnataka over 60 per cent of participants were informed of the availability of travel concessions (Table 14). All AR'T centers require proof of identity and contact address for participants prior to registration for treatment.

Counsellors are required to inform clients to carry these documents with them to the ART center, in order to avoid multiple trips to complete the registration process. Only 68.4 per cent of participants were provided this information.

Most ICTCs are now linked to local community PLHIV networks and have outreach workers. However, less than a third of the participants $(30.2 \%)$ were introduced to a member of a PLHIV network (Table 14). 
Table 14: Topics covered by counsellors during post-test counselling

\begin{tabular}{|c|c|c|c|c|c|c|c|}
\hline & $\begin{array}{c}\text { Andhra } \\
\text { Pradesh } \\
\%(n=276)\end{array}$ & $\begin{array}{l}\text { Maharashtra } \\
\%(n=155)\end{array}$ & $\begin{array}{l}\text { Karnataka } \\
\%(n=329)\end{array}$ & $\begin{array}{c}\text { Uttar } \\
\text { Pradesh } \\
\%(\mathrm{n}=135)\end{array}$ & $\begin{array}{l}\text { Rajasthan } \\
\%(n=88)\end{array}$ & $\begin{array}{l}\text { Gujarat } \\
\%(n=67)\end{array}$ & $\begin{array}{c}\text { Total } \\
\%(n=1044)\end{array}$ \\
\hline $\begin{array}{l}\text { Explain the meaning of } \\
\text { the test result }\end{array}$ & $98.9(273)$ & $94.2(146)$ & $97.9(322)$ & $94.0(126)$ & $94.0(126)$ & $92.5(62)$ & $96.5(1007)$ \\
\hline $\begin{array}{l}\text { Inform about availability } \\
\text { of free ART treatment }\end{array}$ & $89.1(246)$ & $95.5(148)$ & $97.6(321)$ & $82.8(111)$ & $79.5(66)$ & $94.0(63)$ & $91.5(955)$ \\
\hline Discuss ARV treatment & $90.6(250)$ & $77.4(120)$ & $97.6(321)$ & $75.4(101)$ & $67.5(56)$ & $82.1(55)$ & $86.5(903)$ \\
\hline $\begin{array}{l}\text { Discuss the prevention } \\
\text { of HIV transmission }\end{array}$ & $88.0(243)$ & $85.8(133)$ & $94.8(312)$ & $89.6(120)$ & $61.4(51)$ & $95.5(64)$ & $88.4(923)$ \\
\hline $\begin{array}{l}\text { Provide referral slip for } \\
\text { the ARTC }\end{array}$ & $74.6(206)$ & $67.7(105)$ & $98.2(323)$ & $94.8(127)$ & $95.2(79)$ & $94.0(63)$ & $86.5(903)$ \\
\hline Discuss CD4 test & $82.6(228)$ & $69.0(107)$ & $97.0(319)$ & $61.2(82)$ & $65.1(54)$ & $56.7(38)$ & $79.3(828)$ \\
\hline $\begin{array}{l}\text { Ask to revisit ICTC after } \\
\text { registration at ARTC }\end{array}$ & $67.4(186)$ & $69.0(107)$ & $97.6(321)$ & $44.0(59)$ & $69.9(58)$ & $89.6(60)$ & $75.8(791)$ \\
\hline $\begin{array}{l}\text { Provide directions to the } \\
\text { ARTC }\end{array}$ & $56.2(155)$ & $77.4(120)$ & $79.3(261)$ & $76.9(103)$ & $74.7(62)$ & $95.5(64)$ & $73.3(765)$ \\
\hline $\begin{array}{l}\text { Advice on disclosure of } \\
\text { HIV status }\end{array}$ & $65.9(182)$ & $59.1(91)$ & $96.4(317)$ & $79.7(106)$ & $39.8(33)$ & $53.7(36)$ & $73.4(765)$ \\
\hline $\begin{array}{l}\text { Recommend that sexual } \\
\text { partner(s) be tested HIV }\end{array}$ & $68.8(190)$ & 61.3(95) & $72.0(237)$ & $82.8(111)$ & $77.1(64)$ & $80.6(54)$ & $71.9(751)$ \\
\hline $\begin{array}{l}\text { Recommend that children } \\
\text { should be tested }\end{array}$ & $44.2(122)$ & $65.2(101)$ & $74.5(245)$ & $91.8(123)$ & $80.7(67)$ & $68.7(46)$ & $67.4(704)$ \\
\hline $\begin{array}{l}\text { Inform that proof of } \\
\text { identity required at ARTC }\end{array}$ & $74.6(206)$ & $27.1(42)$ & $96.7(318)$ & $51.5(69)$ & $34.9(29)$ & $74.6(50)$ & $68.4(714)$ \\
\hline $\begin{array}{l}\text { Condom demonstration } \\
\text { Inform about travel }\end{array}$ & $38.0(105)$ & $32.9(51)$ & $80.5(265)$ & $22.4(30)$ & $54.2(45)$ & $83.6(56)$ & $52.9(552)$ \\
\hline $\begin{array}{l}\text { concession to reach ARTC } \\
\text { Introduce to PLHA } \\
\text { network }\end{array}$ & $16.3(45)$ & $14.8(23)$ & $63.5(209)$ & $9.0(12)$ & $60.2(50)$ & $26.9(18)$ & $34.2(357)$ \\
\hline
\end{tabular}


Counselling guidelines require counselling to be done in a private space for reasons of confidentiality. Over three-fourths $(77.4 \%)$ of participants reported that they had been counselled in a room with the door closed (Table 15). Counselling guidelines mandate that counselling be done in a place where no other person can overhear the discussion and no other person can see or observe the person being counselled. Although only 40.7 per cent reported that counselling was done out of earshot of others (auditory privacy), and 30.5 per cent reported that counselling was done where the participant could not be seen by others (visual privacy), the vast majority of participants perceived that they had been counselled in private, as reported by 91.6 per cent of participants.

Table 15: Counselling services: Spatial arrangements

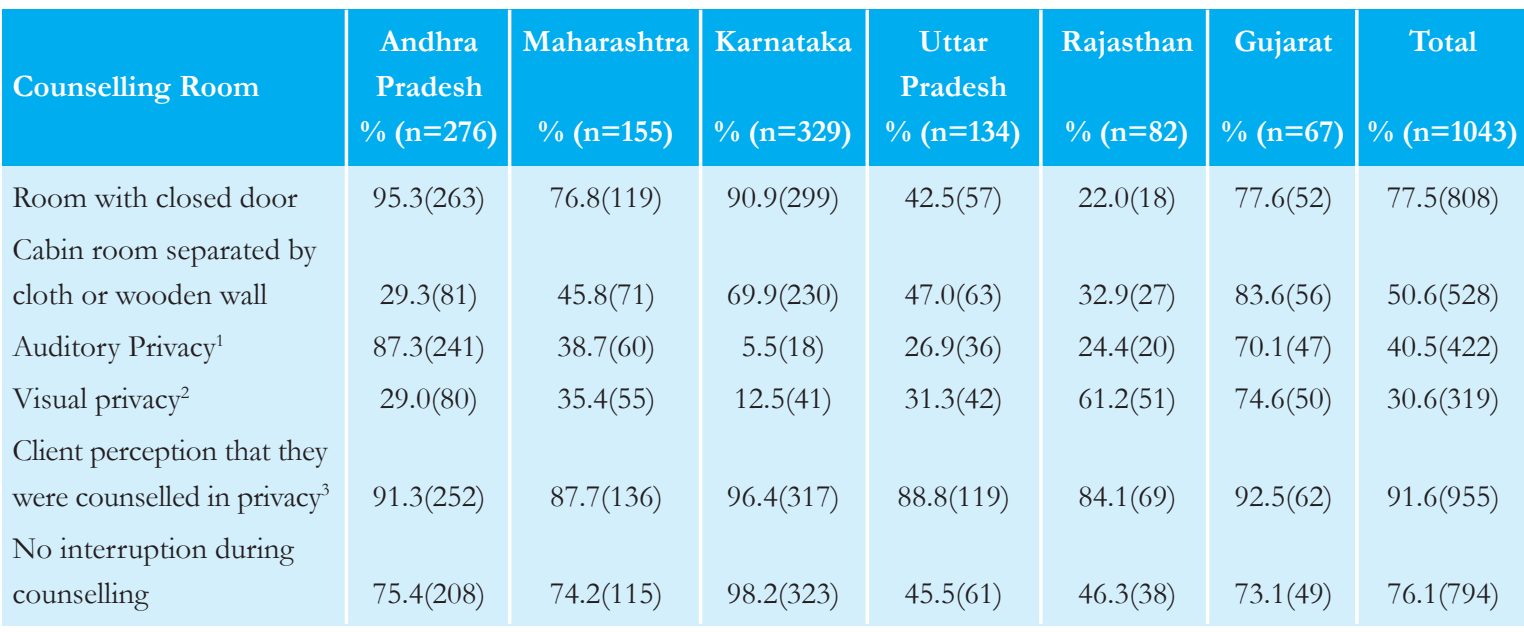

${ }^{1}$ Auditory privacy - counselling conducted in a space where others could not hear the discussion

${ }^{2}$ Visual privacy - client counselled in a space where others could not see the client nor the counsellor

${ }^{3}$ Participant felt comfortable that they s/he had been counselled privately

High levels of satisfaction with counselling services were reported by the majority $(86.8 \%)$ of participants (Table 16). Counsellors appeared to be sympathetic (88.3\%) and attentive (94.1\%). Overall
15.9 per cent participants felt that counsellors were in hurry and rushed through the session and only twothirds of the participants felt that counsellors encouraged or allowed participants to ask questions. 
Table 16: Counselling services: Counsellor's performance

\begin{tabular}{|c|c|c|c|c|c|c|c|}
\hline & $\begin{array}{c}\text { Andhra } \\
\text { Pradesh } \\
\%(n=276)\end{array}$ & $\begin{array}{c}\text { Maharashtra } \\
\%(n=155)\end{array}$ & $\begin{array}{l}\text { Karnataka } \\
\%(n=328)\end{array}$ & $\begin{array}{c}\text { Uttar } \\
\text { Pradesh } \\
\%(n=132)\end{array}$ & $\begin{array}{l}\text { Rajasthan } \\
\%(n=82)\end{array}$ & $\begin{array}{l}\text { Gujarat } \\
\%(n=67)\end{array}$ & $\begin{array}{c}\text { Total } \\
\%(n=1040)\end{array}$ \\
\hline Found counsellor attentive & $95.7(264)$ & $93.5(145)$ & $97.3(319)$ & $56.1(74)$ & $90.2(74)$ & $91.0(61)$ & $94.1(979)$ \\
\hline $\begin{array}{l}\text { Found counsellor in hurry } \\
\text { to end session }\end{array}$ & $18.1(50)$ & $21.3(33)$ & $7.3(24)$ & $31.8(42)$ & $15.8(13)$ & $5.9(4)$ & $16.0(166)$ \\
\hline $\begin{array}{l}\text { Counsellor encouraged } \\
\text { questions }\end{array}$ & $15.5(43)$ & $60.0(93)$ & $90.4(297)$ & $29.5(39)$ & $52.4(43)$ & 61.2(41) & $67.9(706)$ \\
\hline $\begin{array}{l}\text { Counsellor sympathetic } \\
\text { and friendly }\end{array}$ & $78.3(216)$ & $80.0(124)$ & $98.2(322)$ & $89.4(118)$ & $89.0(73)$ & $97.0(65)$ & $88.3(918)$ \\
\hline $\begin{array}{l}\text { Found counsellor critical } \\
\text { of past risk behaviours }\end{array}$ & $8.3(23)$ & $1.9(3)$ & $3.4(11)$ & $6.0(8)$ & $39.0(32)$ & $7.5(5)$ & $7.9(82)$ \\
\hline $\begin{array}{l}\text { Satisfied/very satisfied } \\
\text { with counselling }\end{array}$ & $81.8(226)$ & $90.3(140)$ & $89.3(293)$ & $84.8(112)$ & $84.1(69)$ & $94.0(63)$ & $86.8(903)$ \\
\hline
\end{tabular}

\subsection{Disclosure of HIV status}

It is well recognised that HIV is a highly stigmatised disease and HIV-positive people are careful about disclosing their HIV status freely. Participants were asked whether they had disclosed their HIV status to anyone at their follow-up interview. Therefore data is only available for clients who were interviewed at ART centers $(\mathrm{n}=777)$ and those interviewed in the community $(\mathrm{n}=189)$.

Overall, nearly 70 per cent of participants had disclosed their HIV status to at least one person
(Table 17). Disclosure rates were lower among participants from low prevalence states highlighting to some extent the anxiety and fear in these communities. The lowest disclosure rates were reported from UP (47\%) and Rajasthan (51\%). Even in high prevalence states only around three-fourths of participants had disclosed their HIV status to someone. Disclosure was significantly lower among participants who were interviewed in the community compared to those who had registered at ART centers (54.8\% vs. $72.9 \% ; \mathrm{p}<0.001)$. 
Table 17: Disclosure of HIV status

\begin{tabular}{|c|c|c|c|c|c|c|c|}
\hline & $\begin{array}{c}\text { Andhra } \\
\text { Pradesh } \\
\%(n=254)\end{array}$ & $\begin{array}{c}\text { Maharashtra } \\
\%(n=142)\end{array}$ & $\begin{array}{l}\text { Karnataka } \\
\%(n=320)\end{array}$ & $\begin{array}{c}\text { Uttar } \\
\text { Pradesh } \\
\%(n=116)\end{array}$ & $\begin{array}{l}\text { Rajasthan } \\
\%(n=65)\end{array}$ & $\begin{array}{l}\text { Gujarat } \\
\%(n=65)\end{array}$ & $\begin{array}{c}\text { Total } \\
\%(n=962)\end{array}$ \\
\hline Disclosed to any one & $77.6(197)$ & $71.8(102)$ & $74.1(237)$ & $46.6(54)$ & $50.8(33)$ & $67.7(44)$ & $69.3(667)$ \\
\hline $\begin{array}{l}\text { Disclosed to spouse/ } \\
\text { sexual partner }{ }^{1,2}\end{array}$ & $52.4(133)$ & $60.8(62)$ & $63.7(151)$ & $72.2(39)$ & $72.7(24)$ & $63.6(28)$ & $65.5(437)$ \\
\hline Disclosed to a parent ${ }^{1,2}$ & $39.1(77)$ & $30.4(31)$ & $43.0(102)$ & $61.1(33)$ & $45.5(15)$ & $6.8(3)$ & $39.1(261)$ \\
\hline Disclosed to a sibling ${ }^{1,2}$ & $28.4(56)$ & $16.7(17)$ & $58.6(139)$ & $68.5(37)$ & $63.6(21)$ & $31.8(14)$ & $42.86(284)$ \\
\hline Disclosed to other relative ${ }^{1,2}$ & $29.0(57)$ & $35.3(36)$ & $8.9(21)$ & $24.1(13)$ & $21.2(7)$ & $75.0(33)$ & $25.0(167)$ \\
\hline Disclosed to a friend $d^{1,2}$ & $10.7(21)$ & $13.7(14)$ & $6.4(15)$ & $14.8(8)$ & $12.1(4)$ & $27.3(12)$ & $11.1(74)$ \\
\hline
\end{tabular}

${ }^{1}$ Among those who had disclosed to someone

${ }^{2}$ Multiple responses allowed

Disclosure to sexual partners/spouse was low even among those who disclosed their HIV status to someone. Only 65 per cent had disclosed their HIV status to their spouse (Table 17). Interestingly, highest disclosure to sexual partners/spouses was reported in UP and Rajasthan where overall disclosure was the lowest.

Participants who had disclosed their status were asked if they regretted their decision to disclose. Overall only 42 per cent of all participants did not regret their decision to disclose. Nearly a fifth (18\%) of all participants reported that they were discriminated by their friends, while 8.5 per cent were discriminated by their extended family and several by their immediate family after disclosing their HIV status.

A young HIV-positive male patient from Varanasi told interviewers:

"I was working in Bombay. I was tested because I was very ill and was not getting well. So my friend told me to get tested for HIV since Bombay is full of HIV. So in Bombay people knew my status. They stopped talking to me. When I came to Varanasi I did not tell anyone. Here nobody knows other than my family. My family is very supportive."

A young female participant from Rajasthan narrated: "My husband was very ill and was tested for HIV. My brother-in-law got to know about my husband's status. Everyone's behaviour towards me changed. I was thrown out along with my kids after his death. I was blamed for my husband's illness. I had never worked and now I did not know how to fend for my children. A widow's life is hard; there is no support from family even."

Another young widow from Rajasthan narrated:

"My husband did not tell me about his HIV status, while my sisters-in-law and father-in-law knew he was ill because of HIV. I did not get any support from in-laws or my own family after busband's death. By myself I went for tests. I was very ill and admitted in hospital and a friend belped me. I was referred from Bhilwara to Jaipur since I was HIV-positive". 
Table 18: Reason for regretting disclosure of $\mathrm{HIV}$ status ${ }^{1}$

\begin{tabular}{|c|c|c|c|c|c|c|c|}
\hline $\begin{array}{l}\text { Reasons for } \\
\text { regretting disclosure }\end{array}$ & $\begin{array}{c}\text { Andhra } \\
\text { Pradesh } \\
\%(n=197)\end{array}$ & $\begin{array}{l}\text { Maharashtra } \\
\%(n=102)\end{array}$ & $\begin{array}{l}\text { Karnataka } \\
\%(n=237)\end{array}$ & $\begin{array}{c}\text { Uttar } \\
\text { Pradesh } \\
\%(n=59)\end{array}$ & $\begin{array}{l}\text { Rajasthan } \\
\%(n=42)\end{array}$ & $\begin{array}{c}\text { Gujarat } \\
\%(n=44)\end{array}$ & $\begin{array}{c}\text { All } \\
\%(n=681)^{3}\end{array}$ \\
\hline No regrets & $87.8(173)$ & $65.7(67)$ & $9.7(23)$ & 0 & 0 & $54.5(24)$ & $42.1(287)$ \\
\hline Friends excluded me & $2.5(5)$ & $9.8(10)$ & $25.7(61)$ & $62.7(37)$ & $26.2(11)$ & $11.4(5)$ & 18.9(129) \\
\hline Family secluded me & $5.6(11)$ & $13.7(14)$ & $5.5(13)$ & $8.5(5)$ & $16.7(7)$ & $15.9(7)$ & $8.4(57)$ \\
\hline Lost my job & 0 & $2(2)$ & $14.8(35)$ & $1.7(1)$ & 0 & $15.9(7)$ & $6.6(45)$ \\
\hline Had to move residence & $0.5(1)$ & 0 & $2.5(6)$ & $3.4(2)$ & $7.1(3)$ & 0 & $1.8(12)$ \\
\hline Others $^{2}$ & $3.6(7)$ & $8.8(9)$ & $41.8(99)$ & $23.7(14)$ & $50(21)$ & $2.3(1)$ & $22.2(151)$ \\
\hline
\end{tabular}

These three narratives highlight the challenge HIV-positive people face with regard to disclosure of their HIV status to spouses, family and friends. Disclosure at one end could bring support and at the other end discrimination. Counsellors need to be sufficiently skilled to understand the nuances of each HIV-positive person's context in order to guide them on disclosure. Disclosure to spouses, especially wives, is important not only from the point of view of HIV prevention but also to prepare families to cope in case the husband, who is often the breadwinner in these families, passes away.
Once they got to know about their HIV status, the greatest worry for the majority of interviewees was death $(53 \%)$, not being around to take care of their family $(35 \%)$ or not being able to earn a living (32\%) (Table 19). People worried about not being able to meet medical expenses related to their illness (29\%) and about HIV infection in their children (28\%). As disclosure to spouses/partners was limited (see above), many clients also worried about their spouses learning of their HIV status. 
Table 19: Greatest worry or fear after knowing HIV status ${ }^{1}$

\begin{tabular}{|c|c|c|c|c|c|c|c|}
\hline Greatest worry & $\begin{array}{c}\text { Andhra } \\
\text { Pradesh } \\
\%(n=254)\end{array}$ & $\begin{array}{c}\text { Maharashtra } \\
\%(n=142)\end{array}$ & $\begin{array}{l}\text { Karnataka } \\
\% \quad(n=317)\end{array}$ & $\begin{array}{c}\text { Uttar } \\
\text { Pradesh } \\
\%(n=116)\end{array}$ & $\begin{array}{l}\text { Rajasthan } \\
\%(n=65)\end{array}$ & $\begin{array}{l}\text { Gujarat } \\
\%(n=65)\end{array}$ & $\begin{array}{c}\text { All } \\
\%(n=959)\end{array}$ \\
\hline Death & 42.9(109) & $50.7(72)$ & $58.3(185)$ & $62.9(73)$ & $58.5(38)$ & $43.1(28)$ & $52.7(505)$ \\
\hline $\begin{array}{l}\text { Not being around to take } \\
\text { care of family }\end{array}$ & $44.9(114)$ & $9.2(13)$ & $42.0(133)$ & $44.8(52)$ & $13.8(9)$ & $24.6(16)$ & $35.1(337)$ \\
\hline Ability to make money/work & $31.5(80)$ & $4.9(7)$ & $45.1(143)$ & $32.8(38)$ & $16.9(11)$ & $47.7(31)$ & $32.3(310)$ \\
\hline Medical expenses & $22.4(57)$ & $2.1(3)$ & $49.2(156)$ & $27.6(32)$ & $21.5(14)$ & $27.7(18)$ & $29.2(280)$ \\
\hline Children getting HIV & $15(38)$ & $43.7(62)$ & $34.1(108)$ & $20.7(24)$ & $41.5(27)$ & 21.5(14) & $28.5(273)$ \\
\hline Spouse getting to know & $7.9(20)$ & $27.5(39)$ & $20.2(64)$ & $7.8(9)$ & 23.1(15) & $33.8(22)$ & $17.6(169)$ \\
\hline No worry & $9.8(25)$ & $22.5(32)$ & $11.7(37)$ & $13.8(16)$ & $26.2(17)$ & $1.5(1)$ & $13.3(128)$ \\
\hline Others & $0.8(2)$ & $2.8(4)$ & $2.8(9)$ & $9.5(11)$ & $10.8(7)$ & $9.2(6)$ & $4.1(39)$ \\
\hline
\end{tabular}

${ }^{1}$ Multiple Responses allowed, percentage may not add to a 100

Interviewers asked participants if they knew of other HIV-positive people in their community. The majority (67\%) of participants did not know of any other HIV-positive person or household (Table 20).
However, a fifth of all participants knew between one to three households with HIV-positive people. Even in low prevalence states participants knew of households with HIV infected individuals.

Table 20: Number of households in community with HIV-positive member(s) known to study participants

\begin{tabular}{|l|c|c|c|c|c|c|c|}
\hline & $\begin{array}{c}\text { Andhra } \\
\text { Pradesh } \\
\%(\mathrm{n}=\mathbf{2 5 4})\end{array}$ & Maharashtra & Karnataka & $\begin{array}{c}\text { Uttar } \\
\text { Pradesh }\end{array}$ & Rajasthan & Gujarat & All \\
\hline None & $48.4(123)$ & $85.9(122)$ & $68.8(218)$ & $63.8(74)$ & $84.6(55)$ & $78.5(51)$ & $67.0(643)$ \\
\hline $1-3$ & $39.0(99)$ & $8.5(12)$ & $8.5(27)$ & $32.8(38)$ & $15.4(10)$ & $13.8(9)$ & $20.3(195)$ \\
\hline 4 or more & $12.6(32)$ & $5.6(8)$ & $22.7(72)$ & $3.5(4)$ & 0 & $7.7(5)$ & $12.7(121)$ \\
\hline
\end{tabular}




\subsection{HIV-positive participants interviewed} at ART Centers

ICTC counsellors routinely refer newly diagnosed HIV-positive people to ART centers with referral slips and directions to register as soon as possible. Follow-up interviews were conducted with study participants as soon as they registered at ART centers.

A total of 777 (73.5\%) HIV-positive participants interviewed at ICTCs (baseline: $\mathrm{n}=1057$ ) reached their referral ART centers within two months of their HIV test at the ICTC. Interviews were conducted in ART centers.

\subsubsection{Time taken to reach ART center}

The majority $(92.6 \%$; 709/766) of the participants had returned to the ICTC and collected their HIV test results within one week; 5.5 per cent (42/766) of participants had collected the result within a month and the remainder after a month $(1.9 \%, 15 / 766)$. Eleven participants had inaccurate dates recorded for the date of collection of result and so were excluded from this analysis; most of these participants had tested in the private sector and were required to undertake a repeat HIV test at a public sector ICTC.

Participants reached ART centers after a median of 7 days (IQR: 3, 18 days) after collecting their HIV test result and post-test counselling at the ICTC. Overall, nearly 60 per cent of participants reported at referral AR'T centers within a week, and nearly 30 per cent within a month (Table 21). Twenty participants across all states were registered on the basis of HIV test results from private physicians; they were then referred back to a government ICTC for a repeat test before initiating CD4 testing and evaluation of eligibility for ART; these participants had negative time periods and were not included in the table below.

Table 21: Time taken to register at ART center

\begin{tabular}{|l|c|c|c|c|c|c|c|}
\hline $\begin{array}{l}\text { Time between collecting } \\
\text { HIV test and registration } \\
\text { at ART Center }\end{array}$ & $\begin{array}{c}\text { Andhra } \\
\text { Pradesh } \\
\%(\mathrm{n}=\mathbf{2 0 5})\end{array}$ & Maharashtra & Karnataka & $\begin{array}{c}\text { Uttar } \\
\text { Pradesh }\end{array}$ & Rajasthan & Gujarat & Total \\
\hline 0-7 days & $66.3(136)$ & $66.1(74)$ & $66.4(154)$ & $12.0(11)$ & $62.5(30)$ & $72.2(39)$ & $59.8(444)$ \\
\hline 8-30 days & $26.8(55)$ & $23.2(26)$ & $25.9(60)$ & $60.9(56)$ & $29.2(14)$ & $20.4(11)$ & $29.9(222)$ \\
\hline 31- 60 days & $4.4(9)$ & $10.7(12)$ & $6.5(15)$ & $21.7(20)$ & $4.2(2)$ & $7.4(4)$ & $8.3(62)$ \\
\hline 61 or more days $^{2}$ & $2.4(5)$ & 0 & $1.3(3)$ & $5.4(5)$ & $4.2(2)$ & 0 & $2.0(15)$ \\
\hline
\end{tabular}

${ }^{1}$ Excludes 20 participants who were registered based on HIV test done in the private sector and were then sent for retesting at government ICTC showing reverse dates. Missing data: 14 participants.

${ }^{2}$ Longer time period between collecting their test result and coming back for post test counselling; e.g. in cases where family members collected the test result. 


\section{Reasons for registering at ART center after 30 days of collecting HIV test result}

Participants who registered after a month (30 days) of their HIV test were asked for the reasons for the delay in reaching ARTCs $(\mathrm{n}=77)$. Open ended qualitative responses were collected. Forty-five participants provided reasons; others did not comment. The most commonly cited reasons were: health worker strike $(\mathrm{n}=8)$; being busy with work and family commitments e.g. crop season, death in family etc. $(n=6)$; financial difficulties to travel long distance to ART center $(\mathrm{n}=6)$ and not having someone to accompany them $(n=5)$. Other reasons included: repeating HIV test to confirm HIV status ( $n=4)$; feeling well ( $n=4)$; pregnancy or recent delivery $(\mathrm{n}=3)$; family opposition $(\mathrm{n}=3)$; waiting to test spouse and children $(\mathrm{n}=2)$, completing TB treatment $(n=1)$ or just fear of being diagnosed HIV-positive $(n=1)$. Support offered by outreach workers was mentioned positively by several participants. Selected quotes are given below:

"My husband wanted to test outside [in private laboratory], he also took me with him when he went for the test but only be underwent the test, only be tested. He made me delay even coming here." - 18-year-old woman from Gudivada.

"I have agricultural land so for the last 4 or 5 months I was busy with harvesting and I was not able to come to the center, now I am free so I came here now..." 38-year-old man from Bagewadi "...my husband died from TB. After his death I was very sick, that's why I went to Government hospital...". "Till today, I did not know about my health problem. Nobody told me what is the problem - the counsellor at that time only said there is a problem in your blood, that's all. I took my report today, after one and a half months after my blood test. My family members had misconceptions about my illness and so they took me to all the temples and swamiji, they thought it happened by black magic....when counsellor told me about my HIV status I was shocked. 30-year-old woman from Bagewadi who came back to collect her test result and post-test counselling after 18 months.

\subsubsection{Health care services accessed}

Researchers asked about health care services that participants may have utilised or accessed prior to registering at the ART.

\section{Prior use of $A R T$}

About four per cent $(n=31)$ of participants were receiving ARV medications prior to registering at the ART center (Table 22). More than half of these participants had procured ARVs on advice from private physicians and purchased medications from chemists (18/31); three participants received ART from NGOs and one accessed ART from another government ART center; and seven participants did not provide a response. These participants had been taking ART for a median of 4.5 months (IQR: 2, 12).

Thirty-four participants $(4.4 \%)$ reported that they were concurrently registered at other facilities for ART services (Table 22). Among these participants, the majority $(79.4 \%, \mathrm{n}=27 / 34)$ were registered at other government centers, 44.1 per cent (15/34) were registered with private physicians, and 5.9 per cent (2/34) were registered with NGOs. Multiple responses were permitted on this question; responses show that some participants were accessing services from multiple services providers (eight participants were 
accessing services from both government and private providers, while one participant was accessing services from both the private sector and NGO providers).

Three per cent $(n=25)$ of participants had consulted a private allopathic physician after their
HIV test result. Interestingly, less than one per cent $(\mathrm{n}=7$ ) had consulted a traditional practitioner (ayurvedic, unani or vaidh) but 1.4 per cent $(n=11)$ of participants reported that they were taking traditional medicines.

Table 22: ART health services utilised by clients prior to registration at ART centers

\begin{tabular}{|c|c|c|c|c|c|c|c|}
\hline & $\begin{array}{c}\text { Andhra } \\
\text { Pradesh } \\
\% \text { (n) }\end{array}$ & Maharashtra & Karnataka & $\begin{array}{c}\text { Uttar } \\
\text { Pradesh } \\
\% \text { (n) }\end{array}$ & $\begin{array}{c}\text { Rajasthan } \\
\% \text { (n) }\end{array}$ & $\begin{array}{c}\text { Gujarat } \\
\% \text { (n) }\end{array}$ & $\begin{array}{l}\text { Total } \\
\%(n)^{1}\end{array}$ \\
\hline \multirow[t]{2}{*}{ Used ART previously } & $(n=207)$ & $(n=121)$ & $(n=241)$ & $(n=99)$ & $(n=50)$ & $(n=55)$ & $(n=773)$ \\
\hline & $3.9(8)$ & $2.5(3)$ & 4.6(11) & $6.1(6)$ & 0 & $5.5(3)$ & $4.0(31)$ \\
\hline \multirow[t]{2}{*}{ Registered elsewhere for ART } & $(n=207)$ & $(n=121)$ & $(n=242)$ & $(n=99)$ & $(n=50)$ & $(n=56)$ & $(n=775)$ \\
\hline & $3.4(7)$ & $4.1(5)$ & $5.4(13)$ & $2.0(2)$ & $4.0(2)$ & $8.5(5)$ & $4.4(34)$ \\
\hline Consulted private allopathic & $(n=206)$ & $(n=121)$ & $(n=243)$ & $(n=98)$ & $(n=50)$ & $(n=56)$ & $(\mathrm{n}=774)$ \\
\hline physician after HIV test at ICTC & $8.3(17)$ & $1.7(2)$ & $0.8(2)$ & 0 & $2.0(1)$ & $5.4(3)$ & $3.2(25)$ \\
\hline
\end{tabular}

${ }^{1}$ Denominators vary due to missing information

\section{CD4 tests}

The vast majority of participants had undertaken CD4 count tests to assess eligibility for the initiation of AR'T $(96.4 \%$; 730/757) and of those most of the participants $(96.8 \%)$ had undertaken CD4 tests at government ART centers. CD4 test results were not available for 49 participants. Overall, 55 per cent of participants had CD 4 cell counts less than 250 cells $/ \mathrm{ml}$ making them eligible to start ART immediately. A higher proportion of participants in low HIV prevalence states of UP (61\%), Rajasthan (68\%) and Gujarat (63\%) had advanced immune-suppression ( $<250$ cells $/ \mathrm{ml}$ ), suggesting that people undertook HIV tests when already symptomatic (Figure 16). Of the high prevalence states, Karnataka had a higher proportion of participants with advanced immune-suppression (55\%) compared to Andhra Pradesh and Maharashtra. In Andhra Pradesh and Maharashtra, over a third of the participants had cell counts higher than 350 cells $/ \mathrm{ml}$.

Table 23: CD4 testing

\begin{tabular}{|c|c|c|c|c|c|c|c|}
\hline & $\begin{array}{c}\text { Andhra } \\
\text { Pradesh } \\
\%(n=200)\end{array}$ & $\begin{array}{l}\text { Maharashtra } \\
\%(n=111)\end{array}$ & $\begin{array}{l}\text { Karnataka } \\
\%(n=242)\end{array}$ & $\begin{array}{c}\text { Uttar } \\
\text { Pradesh } \\
\%(n=99)\end{array}$ & $\begin{array}{l}\text { Rajasthan } \\
\%(n=50)\end{array}$ & $\begin{array}{l}\text { Gujarat } \\
\%(n=55)\end{array}$ & $\begin{array}{c}\text { Total } \\
\%(n=757)\end{array}$ \\
\hline CD4 test done & $93.5(187)$ & $97.3(108)$ & $97.5(236)$ & $100(99)$ & $100(50)$ & $90.9(50)$ & $96.4(730)$ \\
\hline $\begin{array}{l}\text { CD4 test done at } \\
\text { government ART center }{ }^{1}\end{array}$ & $98.4(184)$ & $91.7(99)$ & $98.9(232)$ & $97.0(96)$ & $98.0(49)$ & $92.0(46)$ & $96.9(706)$ \\
\hline
\end{tabular}

${ }^{1}$ Of those who had undertaken a CD4 test 
Figure 16: Immune-status of participants who registered at ART centers by state: CD4 cell counts

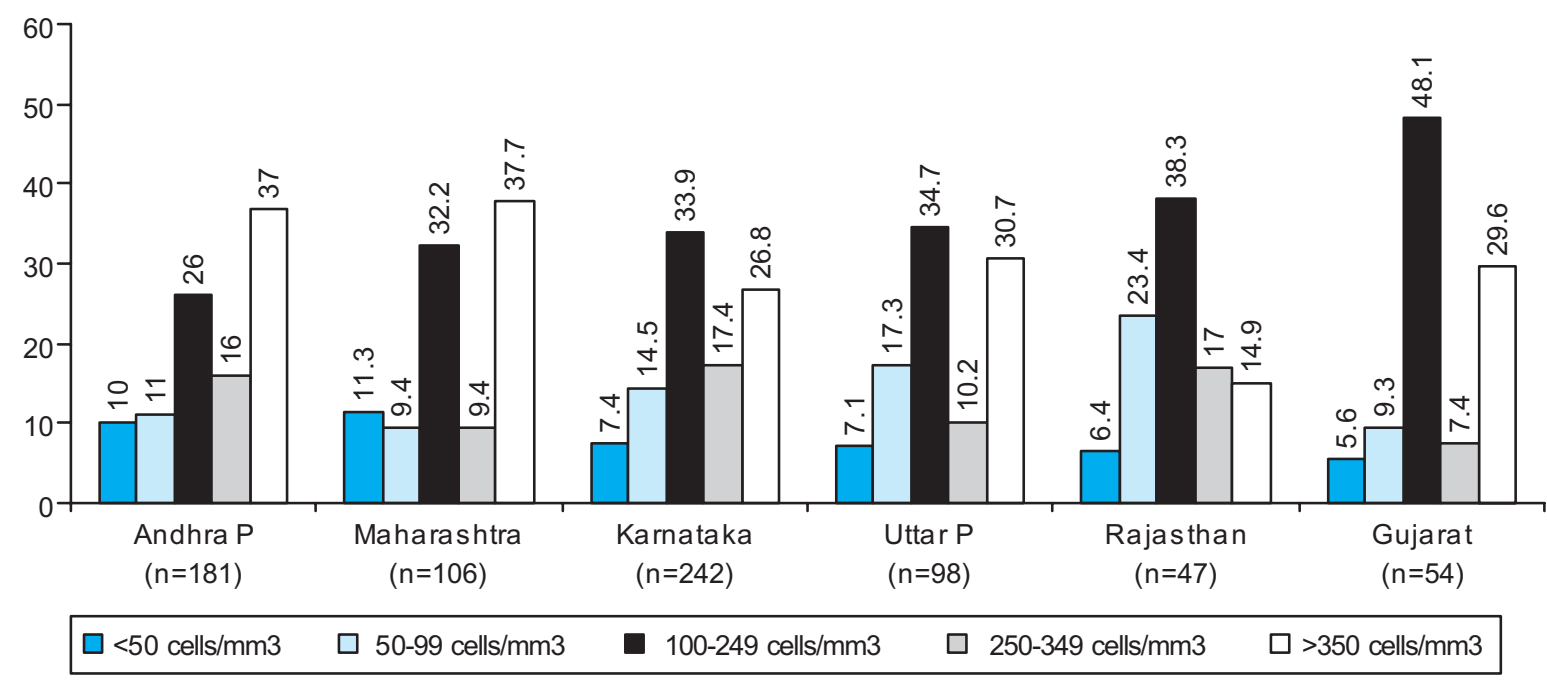

\subsubsection{Access to ART centers}

ICTCs are the first point of contact for HIV-positive people, from where they are then referred to ART centers. Therefore, it is important to understand and assess the process of referrals from the ICTC. The large majority of participants $(89.7 \% ; \mathrm{n}=680)$ who registered at ART centers within 2 months had been informed about the availability of free ART at government centers by the counsellors at the ICTC.

\section{Referral slips and directions}

ICTC centers are required to provide HIV-positive clients a referral slip that includes key information on the date of HIV test, contact details and address of ICTC, PID number, and key socio-demographic information of the client: age and gender. Overall 81.7 per cent of participants reported that they had received referral slips by the counsellor at the ICTC. As ART centers are mostly located in district hospitals, clients benefit from directions to these centers. Almost three-fourths $(73 \%)$ of the participants reported receiving directions to the ART centers. In Andhra Pradesh, however, less than half of the participants received referral slips (45\%) and directions to ART centers $(40 \%)$. (Table 24$)$

Table 24: Referral slips and directions given to HIV-positive clients at ICTCs

\begin{tabular}{|l|l|l|l|l|l|l|l|}
\hline & $\begin{array}{c}\text { Andhra } \\
\text { Pradesh } \\
\%(\mathrm{n}=\mathbf{2 0 8})\end{array}$ & Maharashtra & Karnataka & $\begin{array}{c}\text { Uttar } \\
\text { Pradesh }\end{array}$ & Rajasthan & Gujarat & Total \\
\hline & $\begin{array}{l}\%(\mathrm{n}) \\
\%(\mathrm{n}=\mathbf{2 4 3})\end{array}$ & $\begin{array}{c}\%(\mathrm{n}=\mathbf{9 9}) \\
\%(\mathrm{n}=\mathbf{5 0})\end{array}$ & $\%(\mathrm{n}=\mathbf{5 6})$ & $\%(\mathrm{n}=\mathbf{7 7 7})$ \\
\hline $\begin{array}{l}\text { Provided referral slip by } \\
\text { counsellor at ICTC }\end{array}$ & $45.2(94)$ & $95.0(115)$ & $98.4(239)$ & $82.7(81)$ & $100(50)$ & $100(56)$ & $81.7(635)$ \\
\hline $\begin{array}{l}\text { Provided directions to ART } \\
\text { centers by counsellor at ICTC }\end{array}$ & $40.4(84)$ & $94.2(114)$ & $74.5(181)$ & $93.8(91)$ & $94.0(47)$ & $91.1(51)$ & $73.1(568)$ \\
\hline
\end{tabular}




\section{Locating ART centers in the hospital}

Finding ART centers within hospitals is often challenging for sick, unaccompanied or low literacy patients. Thus clinics need to be well marked with clear directions for clients to find the center easily. The majority of participants reported that centers were well marked $(90 \%)$ with clear and visible sign boards (83\%) directing patients to the center (Table 23). Difficulty in locating ART centers was reported variably from different states. In Rajasthan, only about a quarter of the participants from Rajasthan felt that the ART center in the SMS Hospital was well marked (26\%) with clear signboards $(22 \%)$ to direct clients; and more importantly, only half the participants (54\%) reported that staff at the main reception/inquiry desk were aware of the location of the center and therefore able to assist. Across all states, the majority of participants felt that other hospital staff were generally helpful in assisting clients to locate the ART center, often enquiring on their behalf or accompanying them. Qualitative responses illustrate the difficulties clients faced, as this 35-year-old woman from Mandapeta, Andhra Pradesh reported:

"Searching for ART center is very difficult in

Rajamundhry. It is very difficult to reach ART center.

Only after consulting many hospital staff, we reached it."

Table 25: Location of ART center

\begin{tabular}{|c|c|c|c|c|c|c|c|}
\hline & $\begin{array}{c}\text { Andhra } \\
\text { Pradesh } \\
\%(n=208)\end{array}$ & $\begin{array}{c}\text { Maharashtra } \\
\%(n=121)\end{array}$ & $\begin{array}{l}\text { Karnataka } \\
\%(n=241)\end{array}$ & $\begin{array}{c}\text { Uttar } \\
\text { Pradesh } \\
\%(n=98)\end{array}$ & $\begin{array}{l}\text { Rajasthan } \\
\%(n=50)\end{array}$ & $\begin{array}{l}\text { Gujarat } \\
\%(n=56)\end{array}$ & $\begin{array}{c}\text { Total } \\
\%(n=774)\end{array}$ \\
\hline $\begin{array}{l}\text { ART Center well marked } \\
\text { Clear and visible signboards }\end{array}$ & $88.0(183)$ & $95.0(115)$ & $100(241)$ & $93.9(92)$ & $26.0(13)$ & $100(56)$ & $90.4(700)$ \\
\hline $\begin{array}{l}\text { with directions to ARTC } \\
\text { Staff at hospital Inquiry } \\
\text { Desk know location of }\end{array}$ & $86.1(179)$ & $71.9(87)$ & $95.0(229)$ & $86.7(85)$ & $22.0(11)$ & $91.1(51)$ & $82.9(642)$ \\
\hline $\begin{array}{l}\text { ART center } \\
\text { Other hospital staff } \\
\text { assisted clients to locate } \\
\text { the ART center }\end{array}$ & $58.0(120)$ & $67.8(82)$ & $90.9(219)$ & $92.9(91)$ & $54.0(27)$ & $89.3(50)$ & 76.1(589) \\
\hline
\end{tabular}

\section{People accompanying $H I V$-positive individuals}

HIV is a highly stigmatized disease and PLHIV are careful about disclosing their positive status. At the same time PLHIV may be feeble and ill from advanced HIV disease or illiterate and dependent, and therefore, need help to reach ART centers and navigate hospital departments. Women are particularly vulnerable as many are not used to travelling alone. Participants were asked who accompanied them to the ART center. Across all sites family members accompanied participants to AR'T centers (66\%). A small number of participants were accompanied by friends (Table 26). Less than fifth of the participants reached ART centers unaccompanied by anyone $(16.8 \%)$. 
"My in-law's house is very far from Jaipur.... as the hospital is far away I cannot go alone, there is no one to accompany me so I have brought my brother...” said this 34-year-old woman from Alwar, Rajasthan.

Another 30-year-old woman from Nandigama, Andhra Pradesh said,

"I am very sick; it has been very difficult for me to come to ART center. My friends accompany me and they give me money also for the travelling...."

In many centers as a part of community engagement PLHIV network members are enlisted to support newly diagnosed HIV-positive people who are willing to use this assistance. Overall less than a tenth $(7.2 \%)$ reported that they were accompanied by a PLHIV network member. Those who were accompanied by PLHIV outreach workers appreciated the assistance greatly. Interestingly 40 per cent of the participants from UP reported that they were accompanied by a member of the PLHIV network; this supports anecdotal reports that these networks are very active in UP.

"I was ill when I went to Jaunpur for the test. At the ICTC, PLHIV met me and I came here accompanied by him......it was very helpful.... had no difficulty in finding the ART center." 45-year- old man from Jaunpur, UP.

Table 26: Person accompanying the participant to the ART center

\begin{tabular}{|l|c|c|c|c|c|c|c|}
\hline & $\begin{array}{c}\text { Andhra } \\
\text { Pradesh } \\
\%(\mathrm{n}=\mathbf{2 0 8})\end{array}$ & Maharashtra & Karnataka & $\begin{array}{c}\text { Uttar } \\
\text { Pradesh }\end{array}$ & Rajasthan & Gujarat & Total \\
\hline No one & $16.3(34)$ & $12.4(15)$ & $24.6(59)$ & $2.1(2)$ & $16.0(8)$ & $21.4(12)$ & $16.8(130)$ \\
\hline Family member & $64.9(135)$ & $73.6(89)$ & $64.6(155)$ & $54.6(53)$ & $78.0(39)$ & $73.2(41)$ & $66.3(512)$ \\
\hline Friend & $11.5(24)$ & $6.6(8)$ & $2.9(7)$ & $3.1(3)$ & 0 & $3.62)$ & $5.7(44)$ \\
\hline PLHA network & $2.4(5)$ & $4.1(5)$ & $2.0(5)$ & $40.2(39)$ & $4.0(2)$ & 0 & $7.3(56)$ \\
\hline Out-reach worker & $4.8(10)$ & $3.3(4)$ & $5.8(14)$ & 0 & $2.0(1)$ & $1.8(1)$ & $3.9(30)$ \\
\hline
\end{tabular}

\section{Travel to ART centers}

ART centers in this study were mostly located in district hospitals. In low prevalence states ICTCs were located in CHCs or PHCs in other districts; and in the high prevalence states ICTCs were located in CHCs and PHCs within the same district. In India, districts can be fairly large and can cover a wide geographical area. Therefore, HIV-positive people may need to travel a fair distance to access ART services. In Rajasthan the ICTC at Alwar district hospital was $169 \mathrm{~km}$ from Jaipur while the ICTC at Azamgarh, UP was $87 \mathrm{~km}$ from the ART center in Varanasi. ICTCs in Gujarat were comparatively closer to the corresponding ART center in Mahesana district. In Rajamundhry, Andhra Pradesh the ART center was atleast $40 \mathrm{~km}$ from Kadiam and $35 \mathrm{~km}$ from Mandapeta. Transportation costs and travel time may pose a barrier to seeking ART services. Participants spent a median of 2 hours (IQR: 1.3, 3 hours) to reach their respective ART Center. Each trip cost a median of Rs 90 (IQR: 50,150) equivalent 
of $\$ 2.00$. The majority of participants $(83.4 \%$, $\mathrm{n}=646)$ travelled by bus to reach ART centers; there was no significant variation between states. At some ICTCs in Gujarat, the medical superintendent and district authorities had organized a monthly trip for the ambulance to carry PLHIV to the ART center in Mahesana on a prefixed monthly schedule. In Rajasthan, HIV-positive people were provided travel concessions and given passes.

\section{Problems faced in reaching ART centers}

Participants were asked about the difficulties they faced in reaching the ART centers; open ended qualitative responses were collected. A total of 756 (97\%) participants provided responses. It was encouraging to note that 75.5 per cent of the participants faced no problems in reaching their respective ART centers.

The most frequently cited difficulty was transportation and distance to the ART centers $(11.3 \%$; $\mathrm{n}=84)$ linked with financial constraints and loss of wages $(5.7 \% ; \mathrm{n}=36)$ each time they travelled to the center. Thirteen per cent of participants from Andhra Pradesh; 22 per cent from UP and 20 per cent from Gujarat reported travel costs led to financial difficulties.

"I had financial problems.... for that reason... the day I visited the center I did not eat food that day."

32-year-old female from Azamgarh, UP.

"Two times to come to ART center means lot of expenses that I spent for travelling and loss of work on that day." 30-year-old woman from Kadiam, Andhra Pradesh.

HIV-positive people initiating ART are often sick with advanced immune-suppression. Participants found travelling to distant ART centers challenging due to ill health, fatigue and weakness $(5.3 \%$; $\mathrm{n}=40)$. This was mostly reported from Andhra Pradesh (7.5\%), Karnataka (8\%) and UP (6\%).

"I came to the ART center in a bus, I faced breathing problems, I have TB and I am not able to stand or travel.” 33-year-old woman from Bagewadi.

'I am suffering from paralysis so I am not able to walk properly, that's why my mother came along with me.

She is also facing health problems. I suffered a lot travelling." 30-year-old man from Bagewadi, Karnataka.

A 27-year-old pregnant woman explained, "From my village to ART center is very far, there is no direct bus. Roads are not good. As I am pregnant it is very difficult to travel such a distance."

Several clients $(3 \% ; n=22)$ found it difficult to locate the ART center in the hospital, mostly reported from Andhra Pradesh and Rajasthan.

"I am an illiterate person, I was confused and found it difficult to search and locate the ART center. I had trouble to reach the center properly." 65-year-old woman from Mudhol, Karnataka.

"...identifying the ART center is very critical - $[I$ spent] a lot of time to search the ART center, I was there many hours." 38-year-old male from Mandapeta, Andhra Pradesh.

Some participants $(1.0 \% ; \mathrm{n}=8)$ from Maharashtra reported health worker strike as a reason for multiple visits to the ICTC to obtain their test result and referral slips that interfered with reaching the ART center. Other problems included waiting time at ART centers, multiple visits to the center, and 
childcare. To accommodate the problem of childcare while parents seek services, the ART center in Mahesana has established a play room with an attendant for children.

\subsubsection{Quality of services at ART centers}

To assess the quality of services at ART centers participants were asked about their experience at these centers.

\section{Number of visits required for registration at ART Centers}

To register for treatment services, ART centers require participants to bring the following: a HIV test report from a government ICTC; a referral slip from the ICTC; a ration card or election card as proof of identity, contact address and photographs. Participants may require more than one visit to complete these formalities.

Less than two-thirds $(60.0 \%)$ of all participants were registered on their first visit to the ART center (Table 27). The ART centers in Karnataka were the most efficient in registering clients on their first visit $(91.6 \%)$. Registration on the first visit was less frequently reported in the low prevalence northern states. Participants in UP reported the most number of visits to the ART center in Varanasi: 16.5 reported three visits while 77.3 per cent reported four or

Table 27: Number of visits required for registration at ART center

\begin{tabular}{|c|c|c|c|c|c|c|c|}
\hline & $\begin{array}{c}\text { Andhra } \\
\text { Pradesh } \\
\%(n=208)\end{array}$ & $\begin{array}{l}\text { Maharashtra } \\
\%(n=121)\end{array}$ & $\begin{array}{l}\text { Karnataka } \\
\%(n=239)\end{array}$ & $\begin{array}{c}\text { Uttar } \\
\text { Pradesh } \\
\%(n=97)\end{array}$ & $\begin{array}{l}\text { Rajasthan } \\
\%(n=50)\end{array}$ & $\begin{array}{l}\text { Gujarat } \\
\%(n=56)\end{array}$ & $\begin{array}{c}\text { Total } \\
\%(n=771)\end{array}$ \\
\hline $\begin{array}{l}\text { Number of visits m } \\
\text { ART center for regis }\end{array}$ & & & & & & & \\
\hline One visit & $73.1(152)$ & $67.8(82)$ & 91.7 (219) & $2.1(2)$ & $16.0(8)$ & $1.8(1)$ & $60.2(464)$ \\
\hline Two visits & $20.7(43)$ & $24.0(29)$ & $7.5(18)$ & $4.1(4)$ & $78.0(39)$ & $87.5(49)$ & $23.6(182)$ \\
\hline Three visits & $4.8(10)$ & $5.0(6)$ & $0.8(2)$ & $16.5(16)$ & $4.0(2)$ & $10.7(6)$ & $5.4(42)$ \\
\hline Four or more visits & $1.4(3)$ & $3.2(4)$ & 0.0 & $77.3(75)$ & $2.0(1)$ & 0 & $10.8(83)$ \\
\hline
\end{tabular}

more visits before they were registered into the ART program.

\section{Interaction with counsellors at ART centers}

On registration at the AR'T center, HIV-positive participants receive extensive counselling on ART, on eligibility for treatment, on the lifelong nature of treatment and the importance of adherence to treatment. Patients are also provided counselling for positive prevention and the need for testing the spouse and/or sexual partners and any children. The quality of interaction was assessed.

ART centers cater to a large number of clients referred from several ICTCs across the district and 
clients have to wait to be seen by health workers. Overall, waiting time for clients to be seen by a counsellor at the ART center was short; nearly 60 per cent of participants met the counsellor within 30 minutes (Table 28). A third of clients waited between half to one hour to meet the counsellor, while less than a tenth waited longer than an hour. The initial counselling sessions are important as HIV positive clients receive information on the assessment of eligibility for treatment, interpretation of CD4 tests, ART and adherence. Counsellors at ART centers spent less than 10 minutes with a third of the clients, between 10-20 minutes with nearly sixty per cent of clients and more than 20 minutes with less than a tenth of the clients (Table 28).

Counsellors covered the essential topics listed above to a variable degree and seemed to focus less on some issues. While counsellors did cover the topic of prevention of HIV transmission with the majority of participants (80\%), HIV testing of spouse/ sexual partner and children was not discussed with nearly a third of the participants $(30.5 \%)$. Counsellors discussed treatment with antiretroviral medications during counselling with the majority of participants (80\%); however, almost half the participants (46\%) were not told about CD4 test to assess eligibility for treatment. Nearly a third of the participants were not informed about the need for regular follow-up after starting ART (37\%) or treatment adherence - the need to take all medications correctly, consistently and continuously to prevent treatment failure (33\%) (Table 28). Although, it is possible that the topics of regular follow-up visits and adherence are discussed in greater detail when ART is initiated, an introduction to the issues should be a part of the initial counselling process. Although there is an active effort in many states to utilize PLHIV network members to provide community outreach and support services, this is happening variably in different states. Overall, counsellors told less than a quarter of participants about PLHIV support services. Information about PLHA networks and linking participants with its members was mostly reported in UP and Gujarat, where 55 per cent and 88 per cent of participants, respectively, were told about these services (Table 28).

Participants were asked their impression about the counsellors' attitude and their satisfaction with the counselling interaction. The majority of participants found the counsellors sympathetic (84\%) and their respective sessions with the counsellors conducted in private $(75 \%)$. An area of weakness in the counselling was the opportunity to ask questions and clarify doubts. A third of the participants felt that they were not encouraged to ask questions (30\%) and that their doubts were not clarified to their satisfaction $(33 \%)$. Just over half $(56 \%)$ of the participants reported being satisfied with their interaction with counsellors (Table 28). 
Table 28: ART counselling services at ART Centers by state

\begin{tabular}{|c|c|c|c|c|c|c|c|}
\hline & $\begin{array}{c}\text { Andhra } \\
\text { Pradesh } \\
\% \text { (n) }\end{array}$ & $\begin{array}{c}\text { Maharashtra } \\
\% \text { (n) }\end{array}$ & $\begin{array}{l}\text { Karnataka } \\
\quad \% \text { (n) }\end{array}$ & $\begin{array}{c}\text { Uttar } \\
\text { Pradesh } \\
\% \text { (n) }\end{array}$ & $\begin{array}{c}\text { Rajasthan } \\
\% \text { (n) }\end{array}$ & $\begin{array}{l}\text { Gujarat } \\
\% \text { (n) }\end{array}$ & $\begin{array}{l}\text { Total } \\
\% \text { (n) }\end{array}$ \\
\hline Waiting time to meet & & & & & & & \\
\hline ART counsellor & $(n=208)$ & $(n=117)$ & $(n=241)$ & $(n=98)$ & $(n=50)$ & $(n=56)$ & $(n=770)^{1}$ \\
\hline 30 mins or less & $33.2(69)$ & $71.8(84)$ & $58.2(140)$ & $55.1(54)$ & $86.0(43)$ & $96.4(54)$ & $57.7(444)$ \\
\hline $31-60$ mins & $46.6(97)$ & $23.9(28)$ & $37.3(90)$ & $27.6(27)$ & $12.0(6)$ & $3.6(2)$ & $32.5(250)$ \\
\hline 60 mins or more & $20.2(42)$ & $4.3(5)$ & $4.5(11)$ & $17.3(17)$ & $2.0(1)$ & 0 & $9.8(76)$ \\
\hline Time spent by counsellor & $(n=208)$ & $(n=117)$ & $(n=241)$ & $(n=99)$ & $(n=50)$ & $(n=56)$ & $(\mathrm{n}=771)^{2}$ \\
\hline 10 mins or less & $24.5(51)$ & $47.0(55)$ & $31.1(75)$ & $42.4(42)$ & $38.0(19)$ & $16.1(9)$ & $32.6(251)$ \\
\hline $10-20$ mins & $72.1(150)$ & $47.8(56)$ & $60.6(146)$ & $41.4(41)$ & $56.0(28)$ & $58.9(33)$ & $58.9(454)$ \\
\hline 20 mins or more & $3.4(7)$ & $5.2(6)$ & $8.3(20)$ & $16.2(16)$ & $6.0(3)$ & $25.0(14)$ & $8.6(566)$ \\
\hline $\begin{array}{l}\text { Topics discussed by ART } \\
\text { counsellor }\end{array}$ & $(n=208)$ & $(n=116)$ & $(n=241)$ & $(n=99)$ & $(n=50)$ & $(n=53)$ & $(n=767)^{3}$ \\
\hline $\begin{array}{r}\text { Prevention of HIV } \\
\text { transmission }\end{array}$ & $76.0(158)$ & $74.1(86)$ & 81.3(196) & $90.9(90)$ & $74.0(37)$ & $100(53)$ & $80.8(620)$ \\
\hline $\begin{array}{r}\text { HIV Testing for partner/ } \\
\text { children }\end{array}$ & $64.9(135)$ & $61.2(71)$ & $60.2(145)$ & $94.9(94)$ & $84.0(42)$ & $86.8(46)$ & $69.5(533)$ \\
\hline ARV treatment & $73.6(153)$ & $58.6(68)$ & $85.9(207)$ & $98.0(97)$ & $86.0(43)$ & $98.1(52)$ & $80.8(620)$ \\
\hline ARV treatment is lifelong & $67.3(140)$ & $41.4(48)$ & $77.2(186)$ & $91.9(91)$ & $92.0(46)$ & $96.2(51)$ & $73.23562)$ \\
\hline Need for regular follow-up & $54.8(114)$ & $25.0(29)$ & $72.2(174)$ & $75.8(75)$ & $80.0(40)$ & $96.2(51)$ & $63.0(483)$ \\
\hline $\begin{array}{l}\text { Treatment adherence } \\
\text { CD4 test to assess ART }\end{array}$ & $45.2(94)$ & $51.7(60)$ & $73.4(177)$ & $92.9(92)$ & $90.0(45)$ & $92.5(49)$ & $67.4(517)$ \\
\hline eligibility & $55.3(115)$ & $25.0(29)$ & $54.8(132)$ & $85.9(85)$ & $24.0(12)$ & $77.4(41)$ & $54.0(414)$ \\
\hline Nutrition & $70.2(146)$ & 87.1(101) & $85.9(207)$ & $93.9(93)$ & $88.0(44)$ & $96.2(51)$ & $83.7(642)$ \\
\hline $\begin{array}{r}\text { PLHA networks/social } \\
\text { support }\end{array}$ & $10.1(21)$ & $44.0(51)$ & $5.4(13)$ & $55.6(55)$ & $4.0(2)$ & $83.0(44)$ & 24.3(186) \\
\hline Counsellor's attitude & $(n=208)$ & $(n=117)$ & $(n=240)$ & $(n=99)$ & $(n=50)$ & $(n=56)$ & $(n=770)^{1}$ \\
\hline sympathetic & $55.8(116)$ & $94.0(110)$ & $97.9(235)$ & $94.9(94)$ & $92.0(46)$ & $87.5(49)$ & $84.04(650)$ \\
\hline Privacy during ART & $(n=208)$ & $(n=115)$ & $(n=240)$ & $(n=99)$ & $(n=50)$ & $(n=56)$ & $(n=768)^{4}$ \\
\hline counselling & 61.1(127) & $64.3(74)$ & $93.8(225)$ & $57.6(57)$ & $70.0(35)$ & $94.6(53)$ & $74.3(571)$ \\
\hline ART Counsellor & $(n=208)$ & $(n=115)$ & $(n=240)$ & $(n=99)$ & $(n=50)$ & $(n=56)$ & $(n=768)^{4}$ \\
\hline encouraged questions & 48.6(101) & $80.0(92)$ & $73.8(177)$ & $82.8(82)$ & $82.0(41)$ & $76.8(43)$ & $69.8(536)$ \\
\hline $\begin{array}{l}\text { ART Counsellor clarified } \\
\text { doubts satisfactorily }\end{array}$ & $42.8(89)$ & $78.3(90)$ & $37.5(90)$ & $77.8(77)$ & $82.0(41)$ & $76.8(43)$ & $66.6(511)$ \\
\hline $\begin{array}{l}\text { Satisfaction with } \\
\text { counselling session }\end{array}$ & $(n=208)$ & $(n=115)$ & $(n=240)$ & $(n=99)$ & $(n=50)$ & $(n=56)$ & $(n=768)^{4}$ \\
\hline Fully satisfied & $59.2(123)$ & $64.4(74)$ & $35.8(86)$ & $76.8(76)$ & $70.0(35)$ & $73.2(41)$ & $56.6(435)$ \\
\hline Somewhat satisfied & $34.1(71)$ & $30.4(35)$ & $57.5(138)$ & $19.2(19)$ & $28.0(14)$ & $23.2(13)$ & $37.8(290)$ \\
\hline Not satisfied & $6.7(14)$ & $5.2(6)$ & $6.7(16)$ & $4.0(4)$ & $2.0(1)$ & $3.6(2)$ & $5.6(43)$ \\
\hline
\end{tabular}

${ }^{1-4}$ Note: denominators vary due to missing information 


\section{Interaction with physicians at ART center}

Doctors' consultations usually follow those of the counsellor. Doctors are expected to emphasize and reinforce key messages on treatment and HIV prevention, while also providing specific treatment related information, as their word carries weight. Overall, waiting time to be seen by the physicians was short; 60 per cent of the participants waited less than $30 \mathrm{~min}$ utes to meet the physician. However, 44 per cent of participants reported that their doctor spent less than 5 minutes with them and a further 41 per cent of participants reported that the doctors spent between 5-10 minutes with them. Only 15 per cent of participants reported a meeting of more than 10 minutes with their treating physician.
It appears doctors did not focus on HIV prevention during their interaction with participants. Prevention of HIV transmission was not mentioned to 40 per cent of participants, importance of condom use with partners was mentioned to 60 per cent of the participants, and doctors did not recommend testing for partners and children to 47 per cent of study participants (Table 29). Similarly, treatment adherence and CD4 testing to assess eligibility was discussed with less than half the participants. While over three-fourths of participants $(77 \%)$ found the doctor's attitude sympathetic, almost half of the participants felt that questions were not encouraged (41\%) and that their doubts were not clarified $(46 \%)$. Just over half of the participants reported satisfaction with their interactions with doctors $(52.8 \%)$. 
Table 29: Interaction with Physicians at ART Centers

\begin{tabular}{|c|c|c|c|c|c|c|c|}
\hline & $\begin{array}{c}\text { Andhra } \\
\text { Pradesh } \\
\% \text { (n) }\end{array}$ & Maharashtra & Karnataka & $\begin{array}{c}\text { Uttar } \\
\text { Pradesh } \\
\% \text { (n) }\end{array}$ & Rajasthan & $\begin{array}{l}\text { Gujarat } \\
\% \text { (n) }\end{array}$ & $\begin{array}{l}\text { Total } \\
\%(n) *\end{array}$ \\
\hline \multicolumn{8}{|l|}{ Waiting time to meet } \\
\hline Doctor at ART Center & $(n=195)$ & $(n=94)$ & $(n=146)$ & $(n=99)$ & $(n=50)$ & $(n=55)$ & $(n=639)$ \\
\hline 30 mins or less & $59.0(115)$ & $56.3(53)$ & $76.0(111)$ & $44.5(44)$ & $50.0(25)$ & $80.0(44)$ & $61.4(392)$ \\
\hline $31-60$ mins & $32.8(64)$ & $36.2(34)$ & $10.3(15)$ & $34.3(34)$ & $50.0(25)$ & $16.4(9)$ & $28.3(181)$ \\
\hline 60 mins or more & $8.2(16)$ & $7.5(7)$ & $13.7(20)$ & $21.2(21)$ & 0 & $3.6(2)$ & $10.3(66)$ \\
\hline Time spent by doctor & $(n=195)$ & $(n=94)$ & $(n=146)$ & $(n=99)$ & $(n=50)$ & $(n=55)$ & $(n=639)$ \\
\hline 5 mins or less & $30.3(59)$ & $47.9(45)$ & $74.0(108)$ & $40.4(40)$ & $18.0(9)$ & $38.2(21)$ & $44.1(282)$ \\
\hline 5-10 mins & $51.8(101)$ & $30.8(29)$ & $23.3(34)$ & $39.4(39)$ & $80.0(40)$ & $30.9(17)$ & $40.7(260)$ \\
\hline 10 mins or more & $17.9(35)$ & $21.3(20)$ & $2.7(4)$ & $20.2(20)$ & $2.0(1)$ & $30.9(17)$ & $15.2(97)$ \\
\hline $\begin{array}{l}\text { Topics discussed by ART } \\
\text { counsellor }\end{array}$ & $(n=195)$ & $(n=94)$ & $(n=146)$ & $(\mathrm{n}=99)$ & $(n=50)$ & $(n=53)$ & $(n=637)$ \\
\hline $\begin{array}{r}\text { Prevention of HIV } \\
\text { transmission }\end{array}$ & $79.5(155)$ & $46.8(44)$ & $55.5(81)$ & $46.5(46)$ & $56.0(28)$ & $60.4(32)$ & $60.6(386)$ \\
\hline Condom use & $34.9(68)$ & $33.0(31)$ & $41.1(60)$ & $33.3(33)$ & $56.0(28)$ & $60.4(32)$ & $39.6(252)$ \\
\hline $\begin{array}{l}\text { HIV Testing for partner/ } \\
\text { children }\end{array}$ & $55.4(108)$ & $62.8(59)$ & $37.7(55)$ & $52.5(52)$ & $72.0(36)$ & $56.6(30)$ & $53.4(340)$ \\
\hline $\mathrm{ARV}$ treatment is lifelong & $66.2(129)$ & $69.1(65)$ & $43.8(64)$ & $70.7(70)$ & $82.0(41)$ & $62.3(33)$ & $63.1(402)$ \\
\hline Treatment adherence & $39.0(76)$ & $38.3(36)$ & $35.6(52)$ & $69.7(69)$ & $76.0(38)$ & $52.8(28)$ & $46.9(299)$ \\
\hline CD4 test to assess ART & & & & & & & \\
\hline eligibility & $55.9(109)$ & $53.2(50)$ & $42.5(62)$ & $54.5(54)$ & $24.0(12)$ & $58.5(31)$ & $49.9(318)$ \\
\hline Nutrition & $69.2(135)$ & $73.4(69)$ & $45.9(67)$ & $57.6(57)$ & $74.0(37)$ & $54.7(29)$ & $61.9(394)$ \\
\hline Doctor's attitude & $(n=195)$ & $(n=94)$ & $(n=145)$ & $(n=99)$ & $(n=50)$ & $(n=55)$ & $(n=638)$ \\
\hline sympathetic & $55.4(108)$ & $95.7(90)$ & $89.0(129)$ & $92.9(92)$ & $78.0(39)$ & $65.5(36)$ & 77.4 (494) \\
\hline Doctor encouraged & $(n=195)$ & $(n=94)$ & $(n=146)$ & $(n=99)$ & $(n=50)$ & $(n=55)$ & $(n=639)$ \\
\hline questions & $49.2(96)$ & $67.0(63)$ & $57.5(84)$ & $57.6(57)$ & $86.0(43)$ & $56.4(31)$ & $58.5(374)$ \\
\hline $\begin{array}{l}\text { Doctor clarified doubts } \\
\text { satisfactorily }\end{array}$ & $43.6(85)$ & $69.1(65)$ & $47.3(69)$ & $54.5(54)$ & $84.0(42)$ & $52.7(29)$ & $53.8(344)$ \\
\hline Satisfaction with & & & & & & & \\
\hline Doctor's interaction & $(n=195)$ & $(n=94)$ & $(n=147)$ & $(n=99)$ & $(n=50)$ & $(n=55)$ & $(n=640)$ \\
\hline Fully satisfied & $62.65(122)$ & $46.8(44)$ & $22.45(33)$ & $68.7(68)$ & $84.0(42)$ & $52.7(29)$ & $52.8(338)$ \\
\hline Somewhat satisfied & $31.3(61)$ & $51.1(48)$ & $43.5(64)$ & $24.2(24)$ & $12.0(6)$ & $47.3(26)$ & $35.8(229)$ \\
\hline Not satisfied & $6.2(12)$ & $2.1(2)$ & $34.0(50)$ & $7.1(7)$ & $4.0(2)$ & 0 & $11.4(73)$ \\
\hline
\end{tabular}

* Participants were reluctant to provide responses assessing physicians. 139 participants did not provide responses on this section. 


\subsection{Clients interviewed in the commu- nity (did not register at ART Centers)}

Counsellors at ICTCs refer all people who test HIVpositive to specific ART centers. These ART centers are usually located within the district in high prevalence states. In low prevalence states these centers may be located outside the district as there are fewer ART centers servicing several ICTCs.

The research team tracked participants who did not register at the referred ARTC within two months of their HIV test. Participants were tracked in the community with assistance from ICTC counsellors and PLHIV network members linked to the ICTCs. Locator information was obtained from ICTC registers and study locator forms stored at ICTCs. The research team was successful in contacting and interviewing 189 participants; three of these interviews were done by telephone as clients were unable to meet research interviewers (all in Rajasthan). This section presents results from the interview with these participants.

\subsubsection{Health care services accessed}

Researchers enquired about health care services that participants may have utilised or accessed after their HIV test. Participants were asked whether they had consulted other health care providers and whether they had undertaken further HIV testing (Table 30).

Table 30: Health care services obtained by participants who did not register at referred ART centers

\begin{tabular}{l|c} 
& $\begin{array}{c}\text { Participants interviewed in the community } \\
\%(\mathbf{n} / \mathbf{N})\end{array}$ \\
\hline Additional HIV tests undertaken after testing at ICTC & $4.9(9 / 184)$ \\
Consulted another physician outside referred ARTC after HIV test & $13.3(25 / 188)$ \\
Private allopathic physician & $24(6 / 25)$ \\
Government allopathic physician & $52(13 / 25)$ \\
Ayurvedic/Unani/Vaidh & $24(6 / 25)$ \\
Registered for ART services with other providers & $9.6(18 / 187)$ \\
Where registered: & \\
Other Government ARTC & $44.4(8 / 18)$ \\
Private doctor & $16.7(3 / 18)$ \\
Other/NGO & $11.0(2 / 18)$ \\
No response provided & $27.8(5 / 18)$ \\
Taking traditional medications & $4.3(8 / 185)$ \\
Taking ARV medications & $4.3(8 / 186)$
\end{tabular}




\section{Further HIV testing}

A small number of participants $(n=9)$ had undertaken further HIV testing to confirm their HIV status. Five of these nine participants undertook one additional HIV test while four participants undertook two additional HIV tests. All additional tests were done at private laboratories.

Twenty-five participants had consulted a health care practitioner after their HIV test. Over half of these $(52 \%)$ consulted a government physician (Table $30)$. A quarter $(24 \%)$ of the participants consulted a traditional healer (ayurvedic/unani/vaidh). Eight participants were currently taking traditional medications (Karnataka: 5, Rajasthan: 2 and Gujarat: 1).

\subsubsection{Registration at other ART Centers}

A small proportion $(9.6 \% ; 18 / 187)$ of participants had registered for ART services at other clinics or ART centers. The majority of these participants (44.4\%; 8/18) had registered at government ART Centers in other districts, for a variety of reasons that included stigma, distance and travel concerns, and financial difficulties. Five of the 18 participants were taking ARV medications from other centers: three from private physicians and two from NGOs. Five respondents did not provide responses. Qualitative responses were obtained to provide deeper insight into reasons for why these clients did not register at referral ART centers. A 40-year-old male participant from Gokavaram, Rajamundhry explained why he had registered for treatment at the ART center in Kakinada:
"If we went to the Rajamundhry ART centre for treatment our neighbours or relatives may find out about us. My daughter lives in Kakinada and so we decided to go there."

Another young participant said, "Vijayawada center is too far, I do not have sufficient money for travel so I visited Machbilipatnam ART center which is cheaper for me to reach."

A few participants were seeking ART from private sector physicians and NGOs (Table 29). A 25-year-old male from Vijayawada district explained why he was seeking treatment in the private sector:

"As I said, my relative is working in the government hospital and someone can identify me in there. My relative then will disclose to others. So I have this fear.....I will go to a private hospital for taking treatment, I will not go to government hospital."

\subsubsection{Reasons for not registering at ARTC}

The vast majority $(90.4 \% ; 171 / 189)$ of those who did not register at the referred ARTC had not registered at any other ART center and were not getting ART. These participants were asked reasons for not seeking ARV treatment. Quantitative data and qualitative responses were analysed in this section. Several participants reported multiple reasons for not registering at the referral ART center or seeking treatment. Table 31 provides the main reason (one key reason) cited per participant. 
Table 31: Reasons for not registering at ART centers

\begin{tabular}{|c|c|}
\hline & $\%(n=171)$ \\
\hline Felt fine, did not want to start ART (includes 3 with high CD4 counts) & $29.8(51)$ \\
\hline $\begin{array}{l}\text { Busy so could not visit ARTC (includes death in family [3] and } 6 \text { could not take time off from } \\
\text { work for fear of losing their job) }\end{array}$ & $22.2(38)$ \\
\hline Fear of disclosure & $8.8(15)$ \\
\hline Financial difficulties & $8.8(15)$ \\
\hline Opposition by family members & $5.3(9)$ \\
\hline No one to accompany them to the ART center & $3.5(6)$ \\
\hline Wanted to confirm diagnosis with another HIV test & $3.5(6)$ \\
\hline ARTC very far (6)/ too sick to travel to reach ART (2) & $4.7(8)$ \\
\hline Strike at ART center & $2.3(4)$ \\
\hline Taking TB treatment & $2.9(5)$ \\
\hline Multiple visits required before registration & $1.2(2)$ \\
\hline $\begin{array}{l}\text { Does not have ration card or address proof/temple pujari advised } 21 \text { day fast/taking traditional } \\
\text { ayurvedic medication }\end{array}$ & $2.3(4)$ \\
\hline No response provided & $4.7(8)$ \\
\hline
\end{tabular}

The most commonly cited reason was that participants were well and did not feel the need to start treatment $(29.8 \%)$; this included a few participants who did consult doctors and had high CD4 counts. A 31-year-old married female from Muddebihal, Karnataka said:

"I tested in private hospital and I do not have any bealth problem now - I am fine so why should I go for ART treatment? And my husband is also opposed to me going to the ART center."

Another 30-year-old female from Jaunpur, UP said, "My CD4 report is good, so the doctor told me that you come in March."

Many participants (22 per cent) did not register at ARTCs because they were occupied with work or family responsibilities and work often overlapped with financial concerns as illustrated in the following quote from a 26-year-old female from Indi, Karnataka: "My busband and I are going to work; if I took leave one day then we will lose our job. I cannot go to ART alone because I do not know anything in Bijapur..."

Another young male participant reported, "I am a lorry driver and so when I go on a trip it takes minimum one month time [for me to return] ...."

Another 25-year-old man said, "I do coconut business, this is its season. So I did not go to Vijayawada as I was busy. Need to earn when we have work. If we do not earn it is difficult to survive."

Several participants $(8.9 \%)$ cited fear of disclosure of their HIV status in their communities as the 
main reason for not seeking treatment, as illustrated by this 45-year-old male from Karnataka:

"...I did not visit ART center for taking treatment because in Bijapur [Government ART center] my relative is working...so I did not disclose my status to anybody - it is a matter of prestige. If they come to know about this then they will disclose my status to all my relatives then it will create a problem for the family."

Even though treatment is provided free of cost at government ART centers, participants found the cost of travel burdensome.

"I do not have money to travel to this district hospital. We are poor, I am widowed person. If I am not doing any work, there is no income for my family. I have two children. I am struggling to feed my family daily...." narrated a 35-year-old female from Mudhol, Karnataka.

Several participants felt that ART centers were too far away for them to access services both due to cost of travel as well as the logistics of travel especially for sick participants as mentioned by this 55-year-old male from Jamakhandi, Karnataka:

"I am becoming very weak. I do not have the capacity to go to ART center.... last time I was admitted in government hospital Jamakhandi. So I did not get time to go to Bagalkot ART center."

Some participants also consulted traditional healers and priests, as this 28-year-old female stated:

"I will take ayurvedic medicine for 6 months, if I am not recovering [from HIV infection], then I will take ART medicine."
Another 43-year-old lady from Muddebihal explained:

"I believe in God. I do not want to go to ART center. Without treatment my HIV will cure. The pujari of temple has told me to fast for 21 days for my cure."

Around four participants could not register at the ARTC due to a strike by health workers across ICTCs and ARTCs in Maharashtra in the month of December 2009. Other reported barriers were family objection, ill-health, and not having documents such as ration cards or election ID cards as proof of address for registration purposes. A 40-year-old female participant from Bijapur in Karnataka lamented:

"When I received my test report the counsellor told me that you go to ART center along with HIV report and also election ID card or ration card. But I do not have these cards. He told me if you go to ART center without this they will not give medicines -- that is why I did not visit ART."

Several women reported opposition by their husbands and family as this 26-year-old female participant from Kadiam, Andhra Pradesh reported:

"My husband has not given me permission to go get ART, otherwise I would go.... Now I am feeling comfortable but I know that after some days without ART treatment I will become weak..."

Several participants reported that they had been asked by physicians to first complete their TB treatment prior to registering at the ARTC. In other cases participants felt strained by the number of visits required to complete formalities such as blood tests, chest $\mathrm{x}$-rays prior to receiving their HIV test result and 
referral to the ARTC. This was particularly evident in Andhra Pradesh.

"ICTC counsellor did not give me the HIV report so I visited the ICTC two times; $x$-ray report also they did not give me. I visited the hospital seven times. I have no energy. Local Gudivada hospital I visited many times. Vijayawada city I do not know. I do not know how many times I [will need to] visit the ART center. I [am] scared with no one ready to come with me." 37-year-old male

A few participants were not convinced that they were HIV-positive and wanted to confirm the result by testing again. Others wanted to repeat the HIV test at a private laboratory for better quality of testing. A 25-year-old female reported:

"I do not believe this ICTC result and I did not tell my husband also about my status. I will not take treatment in government hospital, I will go to a private hospital for another HIV test. If this is also found positive then I will take treatment in private hospital only. I will pay for it, I do not care about money. I think private treatment is good."

Another 45-year- old female participant said: "I have decided to take another HIV test privately, that's why I did not go anywhere."

\subsubsection{Awareness about the availability of free ART and CD4 test}

Most participants $(82.9 \% ; 155 / 187)$ had received information about the availability of free ARV medications at government ART centers and had been given referral slips for designated ART centers by the counsellors at ICTCs $(77.5 \%)$. There was variability across states. Over a quarter of the participants from Andhra Pradesh (29.2\%) and a quarter from UP (25\%) reported not having been informed about the availability of free ART. And about half the participants in Andhra Pradesh (44\%) and a third in Maharashtra $(33 \%)$ did not receive referral slips (Table 32). A small proportion of participants had undertaken a CD4 test to assess eligibility for ART. Eighteen participants $(9.6 \%)$ had undertaken a CD4 count test. Of these $77.7 \%(14 / 18)$ of the participants did so at government ART centers. Three participants (16.6\%) had CD 4 tests done at private clinics. One participant was unaware of where the CD4 test was done.

Rajasthan government offers PLHIV travel concessions on bus and rail transport. Participants were asked whether they had been informed about travel concessions on public transport. In Rajasthan 24 per cent $(12 / 50)$ reported that they had received this information from counsellors at ICTCs. Participants from others states did not respond to this question; this facility is not offered in other states.

As a part of community engagement and support for HIV-positive people, many State AIDS Control Organizations are engaging PLHIV from networks to support clients and help with out-reach activities. Participants were asked whether they had received any support from PLHIV support groups. Overall, less than a fifth $(17.1 \%)$ reported that they had been introduced to PLHIV network members by ICTC counsellors and staff. This appeared to be mainly taking place in UP (56\%) and Gujarat (63.6\%) and to a lesser extent in Maharashtra (33.3\%) (Table 32). Interestingly, participants in high prevalence states appeared to be more comfortable about PLHIV or outreach workers visiting them at home than participants 
Table 32: Referral slips and information on services provided

\begin{tabular}{|c|c|c|c|c|c|c|c|}
\hline & $\begin{array}{l}\text { Andhra } \\
\text { Pradesh } \\
\%(n=46)\end{array}$ & $\begin{array}{c}\text { Maharashtra } \\
\%(n=21)\end{array}$ & $\begin{array}{l}\text { Karnataka } \\
\%(n=78)\end{array}$ & $\begin{array}{c}\text { Uttar } \\
\text { Pradesh } \\
\%(\mathrm{n}=17)\end{array}$ & $\begin{array}{l}\text { Rajasthan } \\
\%(n=15)\end{array}$ & $\begin{array}{l}\text { Gujarat } \\
\%(n=11)\end{array}$ & $\begin{array}{c}\text { Total } \\
\%(n=187)\end{array}$ \\
\hline $\begin{array}{l}\text { Informed about availability } \\
\text { of free ART }\end{array}$ & 71.7(33) & $95.2(20)$ & $83.3(65)$ & $70.6(12)$ & $93.3(14)$ & 100(11) & $82.9(155)$ \\
\hline $\begin{array}{l}\text { Provided a referral slip at } \\
\text { ICTC }\end{array}$ & $56.5(26)$ & $66.7(14)$ & $80.8(63)$ & $100(17)$ & $93.3(14)$ & $100(11)$ & $77.5(145)$ \\
\hline $\begin{array}{l}\text { Provided directions to } \\
\text { ARTC at ICTC }\end{array}$ & $23.9(11)$ & $81.0(17)$ & $92.3(72)$ & $87.4(14)$ & $80.0(12)$ & 100(11) & 73.3(137) \\
\hline $\begin{array}{l}\text { Told HIV is curable } \\
\text { Taken CD4 test to assess }\end{array}$ & $8.7(4)$ & $4.8(1)$ & $3.8(3)$ & $17.6(3 / 16)$ & $6.7(1)$ & 0 & $6.4(12)$ \\
\hline disease stage & $10.9(5)$ & $23.8(5)$ & $2.5(2)$ & $25.0(4 / 16)$ & $6.7(1)$ & $9.1(1)$ & $9.6(18)$ \\
\hline $\begin{array}{l}\text { Introduced to a PLHA } \\
\text { network member at ICTC }\end{array}$ & $4.3(2)$ & $33.3(7)$ & $9.0(7)$ & $52.9(9 / 16)$ & 0 & $63.6(7)$ & 17.1(32) \\
\hline $\begin{array}{l}\text { Comfortable with PLHA } \\
\text { or ORW visiting at home }\end{array}$ & $50.0(23)$ & $61.9(13)$ & $64.1(50)$ & $5.9(1)$ & $26.7(4)$ & $54.5(6)$ & $51.9(97)$ \\
\hline
\end{tabular}

in low HIV prevalence states except Gujarat. In UP where nine participants had been put in touch with PLHIV network members, only one reported that he was comfortable in meeting them at home.

\subsection{Registration at ART centers}

To better understand factors that influence patient registration at ART centers further analysis was undertaken. Table 33 presents differences on key socio-demographic and economic variables on bivariate analysis between clients who registered at ART centers within two months of their HIV test $(\mathrm{n}=777)$ and clients who did not register but were interviewed in the community $(\mathrm{n}=189)$. 
Table 33: Differences between registered and non-registered clients on socio-demographic and economic variables (Bivariate analysis)

\begin{tabular}{|c|c|c|c|}
\hline & $\begin{array}{l}\text { Registered at ART } \\
\text { Centers } \%(\mathrm{n}=777)\end{array}$ & $\begin{array}{c}\text { Not registered at } \\
\text { ART Centers \% }(\mathrm{n}=189)\end{array}$ & $\mathrm{Sig}^{2}$ \\
\hline $\begin{array}{r}\text { Males } \\
\text { Females }\end{array}$ & $\begin{array}{l}48.3(375) \\
51.7(402)\end{array}$ & $\begin{array}{l}43.9(83) \\
56.1(106)\end{array}$ & $\mathrm{p}=0.283$ \\
\hline Age $(n=966)$ & $34.8(8.9)$ & $33.2(8.2)$ & $\mathrm{p}=0.017$ \\
\hline Marital status $(n=966)$ & & & \\
\hline $\begin{array}{r}\text { Currently married/Cohabiting } \\
\text { Single } \\
\text { Divorced/separated/Widowed }\end{array}$ & $\begin{aligned} 68.0 & (528) \\
5.7 & (44) \\
26.3 & (205)\end{aligned}$ & $\begin{array}{l}61.9(117) \\
10.6(20) \\
27.5(52)\end{array}$ & $\mathrm{p}=0.040$ \\
\hline 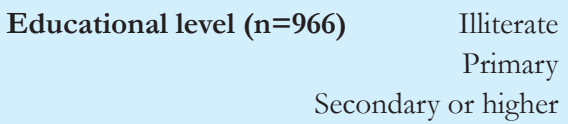 & $\begin{array}{l}54.0(420) \\
16.5(128) \\
29.5(229)\end{array}$ & $\begin{array}{l}65.1(123) \\
11.6(22) \\
23.3(44)\end{array}$ & $\mathrm{p}=0.022$ \\
\hline Employed $(n=966)$ & $78.4(609)$ & $82.5(156)$ & $\mathrm{p}=0.206$ \\
\hline $\begin{array}{r}\text { Number of HIV tests }{ }^{1}(\mathrm{n}=962) \quad \text { One } \\
\text { Two or more tests }\end{array}$ & $\begin{array}{l}66.6(515) \\
33.4(258)\end{array}$ & $\begin{array}{l}72.5(137) \\
27.5(52)\end{array}$ & $\mathrm{p}=0.122$ \\
\hline $\begin{array}{l}\text { Given referral slip for ART by } \\
\text { counsellor at ICTC }(n=957)\end{array}$ & $87.0(670)$ & $88.7(160)$ & $\mathrm{p}=0.600$ \\
\hline Satisfied with counsellor at ICTC & $86.4(666)$ & $88.7(165)$ & $\mathrm{p}=0.528$ \\
\hline Yes & $72.9(565)$ & $54.8(102)$ & $\mathrm{p}<0.001$ \\
\hline $\begin{array}{r}\text { Family member receiving ART }(\mathrm{n}=857) \\
\text { Yes }\end{array}$ & $14.8(104)$ & $15.8(27)$ & $\mathrm{p}=0.749$ \\
\hline $\begin{array}{l}\text { Know HIV-positive people in the } \\
\text { community }(n=961)\end{array}$ & $34.7(268)$ & $51.1(94)$ & $\mathrm{p}<0.001$ \\
\hline 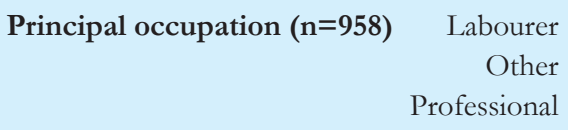 & $\begin{array}{c}52.5(407) \\
40.3(312) \\
7.2(56)\end{array}$ & $\begin{array}{c}66.1(121) \\
30.1(55) \\
3.8(7)\end{array}$ & $\mathrm{p}=0.003$ \\
\hline Own agricultural land $(n=961)$ & $39.6(307)$ & $44.1(82)$ & $\mathrm{p}=0.264$ \\
\hline Live in Pucca house $(n=963) \quad$ Yes & $64.5(501)$ & $57.0(106)$ & $\mathrm{p}=0.057$ \\
\hline Primary source of cooking energy $(n=964)$ & & & \\
\hline $\begin{array}{r}\text { None } \\
\text { Firewood/charcoal } \\
\text { LPG } \\
\text { Others }\end{array}$ & $\begin{array}{c}0.8(6) \\
74.4(578) \\
22.9(178) \\
1.9(15)\end{array}$ & $\begin{array}{c}1.6(3) \\
77.8(147) \\
18.5(35) \\
2.1(4)\end{array}$ & $\mathrm{p}=0.388$ \\
\hline $\begin{array}{l}\text { Owning household items }(\mathbf{n}=961) \\
\text { (television, bicycle/scooter or motorcycle, } \\
\text { almirah/dressing table, sewing machine, } \\
\text { one/two or more pressure cookers/pans, } \\
\text { one/two or more electric fans }(0-8)\end{array}$ & & & \\
\hline $\begin{array}{l}0 \\
1-2 \\
3-5 \\
6-8\end{array}$ & $\begin{array}{c}20.3(158) \\
35.8(278) \\
37.6(292) \\
6.3(49))\end{array}$ & $\begin{array}{l}27.5(52) \\
33.3(63) \\
31.2(59) \\
7.9(15)\end{array}$ & $\mathrm{p}=0.001$ \\
\hline
\end{tabular}

${ }^{1}$ when visiting ICTC $\quad{ }^{2} \mathrm{~T}$ test 
On bivariate analysis, significant differences $(\mathrm{p}<0.05)$ were observed between the two groups: participants who registered at ART centers within 2 months of their HIV test and participants who did not register, on several variables shown in Table 33. Comparisons between the two groups were drawn on the following variables:

Gender: There were no significant gender differences between the two groups $(p=0.283)$.

Age: Mean age was significantly lower for clients who did not register at ART centers compared to those who registered $(\mathrm{p}=0.017)$ suggesting that younger clients are more likely to delay registering at AR'T centers.

Marital status: There were significant differences on marital status between the two groups. The largest difference was observed among single (never married) participants, where the proportion of single participants who did not register at ART centers was twice the proportion of single participants who did register. A marginally higher proportion of divorced or widowed participants did not register at ART centers. By contrast, a higher proportion of married or cohabiting participants registered at ART centers.

Educational level: Significant differences were observed between the two groups on educational level. A higher proportion of illiterate clients did not register at ART centers compared to those who registered. Literate participants with any primary, secondary or higher education were more likely to register at ART centers.

Employment: There were no significant differences between groups.

Number of HIV tests undertaken: There were no significant differences between groups on this variable.

Participants received referral slip for the ART center

from the ICTC: There were no significant differences between both groups with regard to receiving referral slips from the ICTC.

Satisfaction with ICTC counsellors: Participant's satisfaction with their interaction with the ICTC counsellor was explored. No significant differences emerged between groups.

Disclosure of HIV status to someone: There were significant differences between the two groups on disclosure of HIV status. Among those who did not register at ART centers, the proportion of persons who had disclosed their HIV status to someone was significantly lower compared to those who had registered.

Have a family member receiving ART: There were no significant differences between the two groups with regard to having a family member receiving ART.

Knowledge of HIV-positive persons in the community: Significant differences were observed between the two groups. A significantly higher proportion of participants who did not register knew HIV-positive persons in the community.

Economic variables were explored. There were differences on certain economic indicators suggesting that participants with lower incomes or those who were economically weak were less likely to register for treatment. A higher proportion of participants who lived in pucca houses, owned a higher number of household goods such as a pressure cooker, sewing machine, fans, television or a vehicle registered at AR'T centers compared to those who did not register. Participants with households where the principal occupation was labour were significantly more likely not to register at ART centers. Ownership of agricultural land was not significantly different between the two groups.

CD4 cell counts were not included in this comparison as the majority of clients interviewed in the community had not undertaken this test. 


\subsection{Conclusions}

The study was designed to document the uptake of ART services in the public sector and to determine the reasons why some people do not access these services even when these are available for free in the public sector . A cohort of 1057 newly diagnosed HIVpositive people were followed over 2 months. Almost three-fourths $(73.5 \%$; $\mathrm{n}=777)$ of the cohort registered at ART centers within two months of collecting their HIV test result. Of those who did not register at ART centers, 17.9 per cent $(n=189)$ were successfully interviewed in the community and 5.6 per cent ( $n=60)$ were tracked but not interviewed and only around 3 per cent $(n=31)$ participants were untraced and lost to follow-up. This provides evidence to the program that clients can be successfully tracked in the community.

The majority of the HIV-positive participants, who did not register at ART centers and were interviewed in the community, were not accessing ART nor had undertaken CD4 tests to assess their eligibility for treatment. This places these clients at risk of delaying treatment. A small number of HIV-positive clients $(\mathrm{n}=18)$ had registered at government ART centers in other districts for reasons of confidentiality, financial constraints and centers being close to their place of residence. And a very small proportion of participants were accessing the private sector, suggesting that the public sector is still the main provider of services for this population. Procedures need to be in place for clients to inform ICTC or ART centers that they have registered for treatment at other centers. Linking client information in ICTC registers to the registers at ART centers by recording PID numbers could provide the necessary link. Revisiting ICTC by clients after registration at ART centers may be emphasized; this is being done at some centers. Formalising the inclusion of follow-up information in the ICTC register may direct counsellors to collect this information routinely through phone calls or outreach activities. The proposed central national registry for ART services will be very useful.

HIV-positive clients interviewed in the community did not register at referral ART centers for a variety of reasons. A perception of relatively good health removed the urgency to register immediately for several clients (30\%), while work and family engagements kept others away from the ART center (22\%). The fear of disclosure of their HIV status, being recognised by villagers or relatives and resulting stigma was the overriding concern for many others (9\%). Although ART is offered free at government centers, financial difficulties and travel expenses were deterrents for several participants (9\%). Family opposition comprised the fifth most commonly cited reason (5\%). Other reasons included the distance of ART centers compounded with severe illness, which prevented travel for the participants who probably needed ART most. In a few cases, participants were waiting to complete their tuberculosis treatment prior to registering at ART clinics.

Bivariate analysis indicated that younger clients, single clients and those working as unskilled manual labour were significantly more likely to not register at ART centers. Further, non-disclosure of HIV status and knowledge of HIV-positive people in the community were also associated with a higher probability of 
not registering at ART centers; highlighting the continuing role of stigma in the community. Additionally, indicators suggestive of financial incapacity (e.g. working as manual labour, not owning household items such a pressure cooker, fans, vehicle or a sewing machine) were significantly associated with a higher probability of not registering for ART services. Similar factors emerged from the analysis of secondary data from ART centers in Phase 1 of this study. Further, these issues were also mentioned by clients who had registered at ART centers but continued to face difficulties while accessing services. If not addressed, these may be the very factors that contribute to non-adherence at a later stage.

Counsellors at ICTCs and health workers at hospital departments such as TB and ANC clinics from where clients are routinely sent for HIV testing should be cognisant of these factors and quick to identify clients at risk of disappearing into the community. Identification of an at-risk client should trigger a closer follow-up and community outreach intervention. It is of concern that 32 newly diagnosed HIVpositive people who did not register at ART centers had died within 2 months of their HIV test. These participants, with presumably advanced HIV disease, did not receive the benefit of the free ART program. These participants could have benefitted from a more aggressive follow-up and tracking in the community.

Disclosure and stigma continue to be important barriers to accessing services. Intensive counselling and support to address and facilitate disclosure of HIV status and manage fears related to loss of confidentiality are urgently needed. There should be provision for HIV-positive participants to be offered a choice of government ART centers to choose from, especially in states where a wider network of ART centers exists. Giving people a choice would go a long way in addressing some of the confidentiality issues confronting newly diagnosed HIV-positive people as well as addressing the barrier of distance to ART centers. Fast tracking the opening of link AR'T centers would further serve to reduce the travel and related costs thereby facilitating uptake of services. Best practices that could be emulated include the provision travel concessions on public transport for PLHIV, as is being provided in Rajasthan; and the organisation of transport services (hospital ambulance) from ICTCs to referral ART centers on a fixed monthly schedule, as is being done in Mahesana, Gujarat.

The study also provides an assessment of the quality of counselling at ICTCs from interviews with HIV-positive people undertaken immediately after post-test counselling; and of the quality of counselling at ART centers from interviews conducted after registration at the ART centers. Overall, clients were satisfied with counselling services at ICTCs. Topics that were inadequately covered included emphasis on partner testing, condom demonstration, explanation on the window period and information on PLHIV networks. Counselling at ART centers suffered from similar weaknesses, including insufficient information on the need for regular follow-ups and adherence to treatment, CD4 tests, and HIV testing of spouse and children. Doctors appeared to rush through appointments with clients. These weaknesses could be addressed through a more rigorous monitoring of services including periodic low cost state level evaluations through exit interviews and client satisfaction surveys. Health system issues, such as the shortage of HIV testing kits in ICTCs and health worker strikes 
also contributed to impeding registration at ART centers. In addition, certain local policies requiring chest $\mathrm{x}$-rays and other checkups to be done before referring clients to ART centers entail multiple trips for clients. Although designed to facilitate uptake, this practice may be having a negative impact, as multiple trips prove onerous and financially burdensome for sick and economically weak clients. A review of these policies may be considered.

In conclusion, the majority of newly diagnosed HIV-positive people do register at ART centers. While barriers that deter HIV-positive people from accessing treatment services do exist, they are not insurmountable. Addressing client and health system barriers would serve to increase uptake of services.

\section{Recommendations:}

- The study has demonstrated that programs can successfully track HIV positive persons in the community. Attempts must be made to track all newly diagnosed HIV positive people in the community. Efforts can be made by both clients and health providers.

a) Counsellors should routinely follow newly diagnosed positive people over two to three months after the HIV test, to determine whether they have registered at any ART center and if not reasons for not doing so. This could be done through phone calls or outreach workers. ICTC registers could be modified to include additional information on registration at ART centers.

b) Clients must be asked to visit the ICTC or call the counsellor after they register at ART centers.
While this is being done at some centers, implementation at a wider level may be considered.

- Enlisting support from PLHIV networks for clients to reach ART centers is an important additional resource for health providers. This is not being implemented across all sites; this link can be strengthened to improve enrolment and follow-up in the community.

- ICTC counsellor's scope of work could be expanded to undertake an assessment of health and social status of newly diagnosed HIV positive people. The objective would be to identify persons who may be sick with advanced disease and in need of urgent medication; or having characteristics that may predict delayed registration or non-registration at ART centers - - e.g. manual labourers, clients from a poor economic status, and illiterate clients who may require additional support to reach ART centers. Counsellors may be trained to initiate a more aggressive follow-up plan for these clients.

- Healthy clients would benefit from more focussed counselling on the importance of registering and assessing eligibility for ART even if they are in good health.

- Several clients found travelling a long distance to ART centers burdensome for several reasons -- e.g. ill health, financial difficulties, lack of transport arrangements, not having people to accompany them, etc. This is not only a barrier to uptake of services but also for long-term adherence to treatment for patients on treatment.

a) In low prevalence states where ART centers receive clients from several districts, and in 
some cases neighbouring states (as in the case of Varanasi), Link ART centers need to be established quickly. At present Link ART centers only provide delivery of ART medications. Weekly visits by specialists from the ART center and arrangements to collect and transport blood for CD4 cell counts could be considered.

b) Enlisting support of PLHIV networks to accompany clients to ART centers should be encouraged.

c) Travel concessions on public transport can be provided.

- Fear of inadvertent disclosure of status and resulting stigma is an important barrier to seeking ART services. The program may consider offering choice of ART centers to newly diagnosed HIV positive people for the initial evaluation and registration, and long-term follow up. This would allow clients to register safely and without fear. Clients could move to a center closer to their home once they felt comfortable with their HIV positive status and treatment.

- Closer monitoring of counselling at ICTCs and ART centers is required at the state and district level. Routine monitoring visits should be planned that include a review of service data as well as some exit interviews with clients and/ or observation of counselling sessions where possible.

- Data quality issues were noted at both ICTC and ART centers.

a) Rigorous and regular monitoring of data quality at ICTCs and ART centers is urgently needed. Monitoring visits should include a review of registers.

b) Harmonization of data collection at ICTC and ART centers is required. Coding of key variables should be similar at both sites.

c) Linking of ICTC and ART center data is urgently needed for program monitoring. Client PID numbers (unique ID) should be recorded in ART registers to link the two data bases. A joint monthly review of linked data by ICTC counsellors and ART counsellors could ascertain the number of clients who registered successfully and those who did not register and therefore need to be tracked in the community. 


\section{References}

Department of AIDS Control, Ministry of Health and Family Welfare, Government of India. Annual report 2008-09. Available at www.nacoonline.org/ upload/.../Annual_Report_NACO_2008-09.pdf

Sarna, Avina, Indrani Gupta, Sanjay Pujari, A. K. Sengar, Rajiv Garg, and Ellen Weiss. 2006. Examining adherence and sexual behavior among patients on antiretroviral therapy in India. Horizons Final Report. Washington, DC: Population Council. http://www. popcouncil.org/pdfs/horizons/indiaart.pdf

Sarna, A., S. Pujari, A.K. Sengar, R. Garg, I. Gupta, and J. van Dam. Adherence to Antiretroviral Therapy and its Principal Determinants amongst HIV Infected Patients in India. Ind J of Med Res 127; January 2008; pp. 28-36.

Sarna, A., J. Ahmad, G. Alexander, V. Mahendra, A. Rau, A. Singh and N. Rutenberg. 2007. Exploring barriers to accessing care and treatment fro
HIV-infected children in India: A diagnostic study. Research update, Population Council http:/ / wmw. popcouncil.org/pdfs/IndiaUpdate/IndiaUpdate_Barriers. $p d f$

World Bank in India. India data and statistics. HNP data bank. Available at http:/ / databank.worldbank. org/ddp/home.do. Accessed on May 15, 2010.

Bhat, R., Maheshwari, S.K. 2004. Human Resource Issues and its Implication for Health Sector Reforms; Working paper No. 2004-01-04, Indian Institute of Management.

Bhat, R., Maheshwari, S.K., Saha, S. 2004. Treating HIV/AIDS patients in India with antiretroviral therapy: a management challenge. Indian Institute of Management: Ahmedabad.

Quick Poverty Score India (QPS). Available at: bttp:// www.cpc.unc.edu/ measure/tools/poverty/quickpoverty-score 


\section{Annex 1. Quick Poverty Score for India}

1. How many people aged $0-17$ are in this household?

Enter '00' if None, Enter ' 05 ' if 5 and so on

2. What is the household's principal occupation?

Labourers - 01

Others -02

Professional -03

3. Is the residence all pucca (burnt bricks, stone, cement, tiles and jack board/cement plastered reeds, timber, galvanized tin or asbestos cement sheets)?

Yes -01

$\mathrm{No}-02$

4. What is the household's primary source of energy for cooking?

Fire wood chips / charcoal - 01

None -02

Others -03

LPG - 04

5. Does the household own a television?

Yes -01

No -02
6. Does the household own a bicycle, scooter or motor cycle?

Yes -01

No -02

7. Does the household own an almirah/dressing table?

Yes -01

$\mathrm{No}-02$

8. Does the household own a sewing machine?

Yes -01

$\mathrm{No}-02$

9. How many pressure cookers or pressure pans does the household own?

None -01

One -02

Two or more -03

10. How many electric fans does the household own?

None -01

One -02

Two or more -03 


\section{Annex 2. Informed consent for people testing positive for HIV/AIDS at ICTC centers (Consent for Baseline survey)}

\section{Purpose of the study}

(Greet the man/woman). My name is

The Population Council is conducting a study to learn more about the problems HIVpositive persons face in receiving care and treatment. This study is being sponsored by the NACO (National AIDS Control Organization), MOH\&FW of the

Government of India. NACO will use this information to improve HIV testing and treatment services for HIV positive persons. Your participation in this study will help NACO to improve the quality of services for you and other people who need treatment for HIV infection.

\section{Procedure}

You will be asked to participate in two interviews at an interval of 2 months. The first interview will be done today. The second interview will be done in the next 2-3 months. Today, you will be asked questions on what you know about HIV, treatment with ART, social support available for PLHAs, quality of services at ICTCs, difficulties people face in getting treatment for illnesses and for HIV infection. After the interview you will receive a referral number/card to show at the ART treatment centers.

We will need your contact information to contact you for your second interview. We understand that you may want to keep your HIV status secret. Please give us an address and telephone number, that you are comfortable with, where we can reach you. Please tell us how you would like the research staff to identify or introduce him/her self, a convenient time when you would be available and the form of greeting the research staff can use. Your contact information will be stored carefully under lock and key. The research staff will arrange to meet you at a convenient time and location for the second interview.

We would like to ask for your consent to be interviewed today, in private by one of our trained interviewers.

\section{Benefits and Risks}

If you agree, your participation will help organizations like the ICTCs and its staff in addressing PLHA's needs more efficiently. Some of the questions that you will be asked may be sensitive or personal in nature and perhaps make you uncomfortable. The interviewer will not insist on answers to all questions. Your participation in the study may not benefit you directly. Whether you agree or not, both you and your family will receive all of the health care services that are normally provided through the government health system.

There is a minimal risk of someone learning of your HIV status when the research team contacts you for the second interview. We are giving you the contact information of our research officer. If you need our assistance, you can contact us on this phone number. We will assist you to get counselling support from a counsellor, PLHA support group or NGOs. We will also be able to offer counselling to family members. 


\section{Compensation}

You will receive Rs 100 towards reimbursement of transport costs for each of the two interviews.

\section{Offer to answer questions and freedom} to withdraw from the study

You can refuse to respond to any question and can stop the interview at any time. You or your family will not be deprived of any services, if you decide to drop out of the study. The interview will take approximately 20 minutes. Participation is completely voluntary.

\section{Confidentiality}

Everything that you report during the interview will be kept strictly confidential and your name will not be recorded on the questionnaire. The contact information that we collect is kept separate from the questionnaire and will be kept under lock and key. This information will only be used by the researchers and will be used only for contacting for the study's follow-up interview. All records of your interviews and data collected from medical records will be kept in a safe place under lock and key. These will be destroyed after the completion of the study.

\section{Subject's Statement}

I have read the consent document regarding my participation in the study / the consent document regarding my participation in the study has been read out to me. I have been given a chance to ask questions and my questions have been answered to my satisfaction.

I understand that all records will be kept private, will be destroyed after the study and that I can leave the study at any time. I have also understood that my decision not to be in this study or to leave the study will not affect the services I will receive.

I agree to be in this study as a volunteer.

Name of the subject

Signature of the subject:

Date:

Signature of a witness:

Date:

[Tear Here]

Contact information:

Name:

Address:

Telephone:

Any contact telephone, if not of self: (name of person and number)

ART referral card no:

Information and salutation to be used when contacting subject: 


\section{Annex 3. Understanding the factors affecting enrollment of PLHAs into ART services in India}

\section{Baseline Survey}

\section{Interview to be conducted at the ICTC}

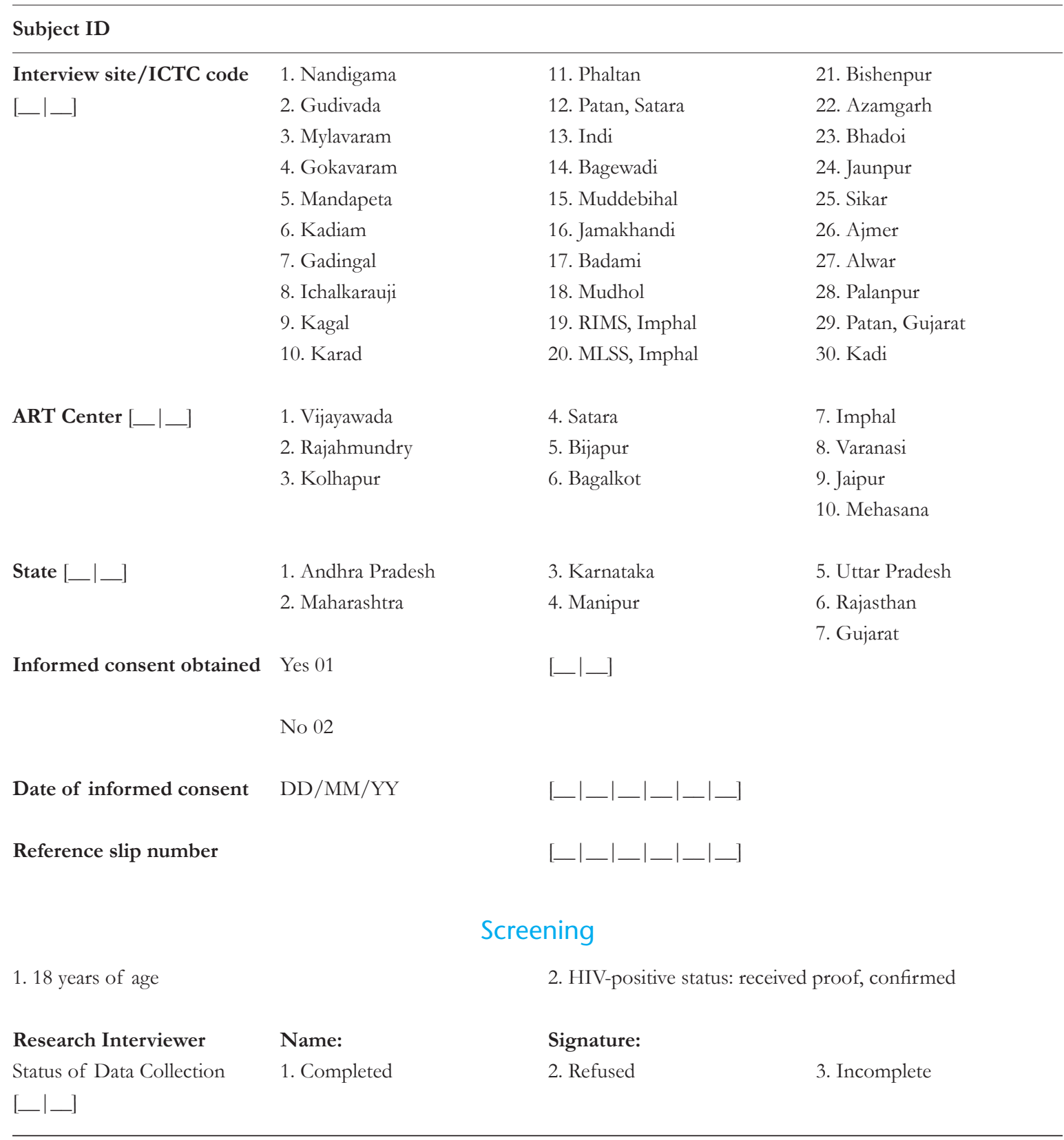




\section{SECTION I: BACKGROUND CHARACTERISTICS}

\begin{tabular}{|c|c|}
\hline QID & Question \\
\hline 101 & Sex \\
\hline 102 & Age in Years \\
\hline 103 & $\begin{array}{l}\text { What is the highest level of education } \\
\text { you have had? }\end{array}$ \\
\hline & Instruction: \\
\hline & For education enter completed school years from \\
\hline & $\begin{array}{l}1 \text { to } 12 \text {; add one year for each year of university } \\
\text { education }\end{array}$ \\
\hline 104 & $\begin{array}{l}\text { If attended vocational training, years of } \\
\text { vocational education. }\end{array}$ \\
\hline 105 & What is your current marital status? \\
\hline 106 & $\begin{array}{l}\text { What is the HIV status of your spouse? } \\
\text { Instruction: } \\
\text { If married or cobabiting refer to current spouse, if } \\
\text { widowed refer to dead spouse }\end{array}$ \\
\hline
\end{tabular}

Was the death of your spouse due to HIV?

What is your religion?

\section{Response options/codes}

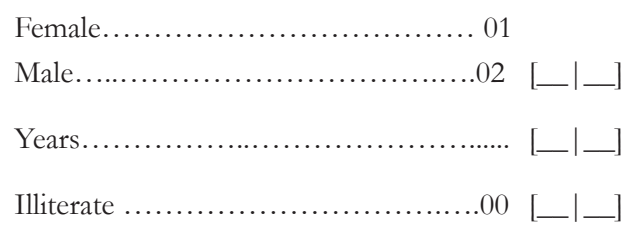

Completed years of education

No formal education, but can read and

write ..... .77

Years.

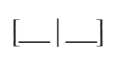

Currently married.....

01 [_l_]

Cohabiting (Not married but living

with partner).

Single (Never married)

Divorced or separated.

Widowed.

HIV negative

HIV positive.

Not known ...03

$\begin{array}{ll}\begin{array}{l}\text { Coded } \\ \text { response }\end{array} & \begin{array}{l}\text { Skip } \\ \text { pattern }\end{array}\end{array}$

Yes.

Yes.................................. 01

No.................................02

Don't Know.........................99

Hindu ............................. [_|_]

Muslim............................02

Christian.............................03

Sikh.............................04

Jain............................... 05

Buddhist...........................06

Other religious groups................07

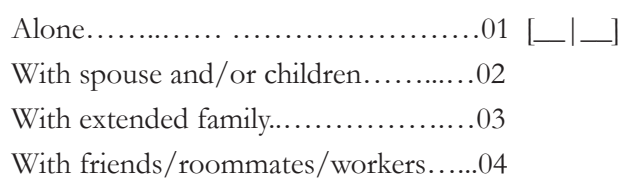

If '03' skip to Q108 If '05' skip to Q107

Skip to

Q108 


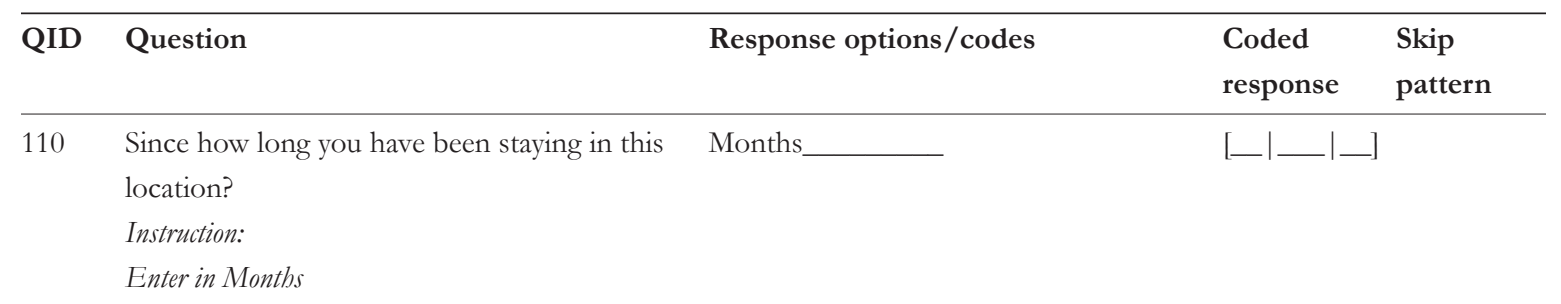

Now I would like to ask you a few questions about your biological children and their HIV status

\section{Instruction: Check Q105=3, (Single; Never Married) skip to Q114}

111 How many biological children do you have?

Instruction: If none write 00

How far is your place of work from your place of residence?

Instruction:

If workplace same as place of residence enter 00, if other place, enter distance in kilometers

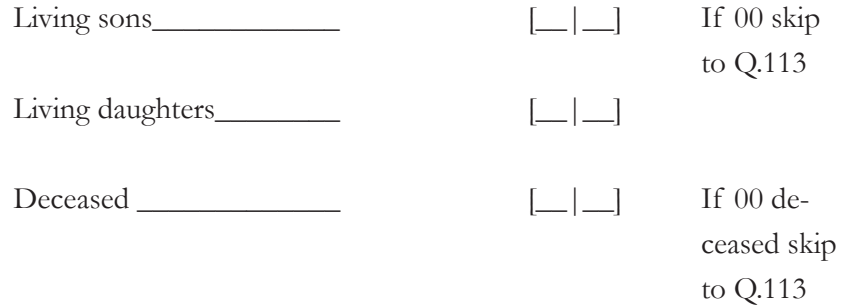

Yes . $.01[-\mid-]$

No..................................02

Sons................................ [_

Daughters.......................... [_

Not working $\ldots \ldots \ldots \ldots \ldots \ldots \ldots \ldots . . . . . \ldots 0$ [_|_] If 00 skip

Agricultural work.....................01 to Q. 118

Manual labour..........................02

Handicrafts/stitching................03

Factory worker......................04

Government employee...............05

Shopkeeper..........................06

Aganwadi worker.....................07

Petty Business........................08

Shops/Business.....................09

Health worker........................10

Unskilled labour........................11

Carpenter/Masson....................12

Cycle rickshaw driver..................12

Teacher............................13

Contractor............................14

Truckers/transportation...............15

Other (specify) ..................... 88

Same village.........................01 [_|_]

Within the district....................02

Outside the district...................03

Distance in kilometers ___ [_ 


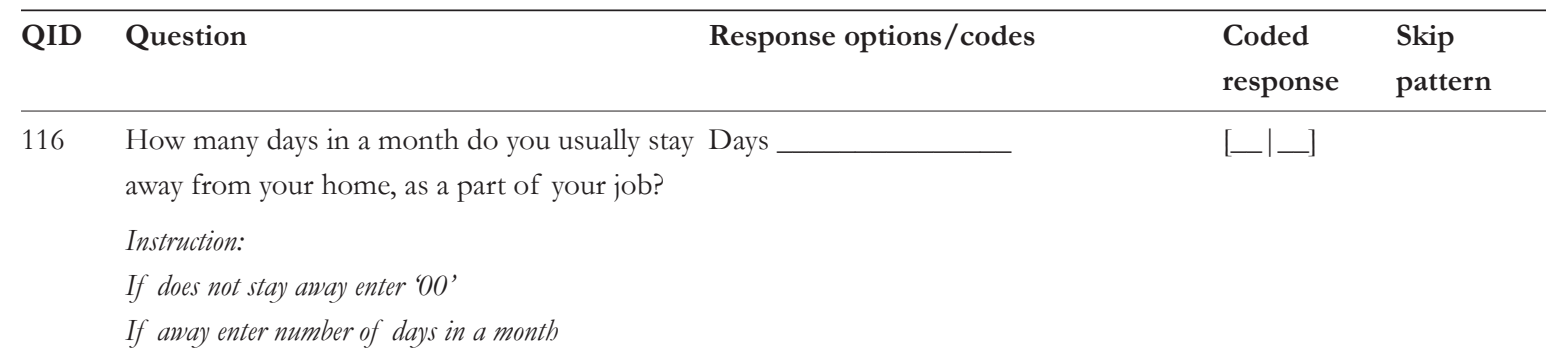

117 Have you travelled outside the district for work in the past two years?

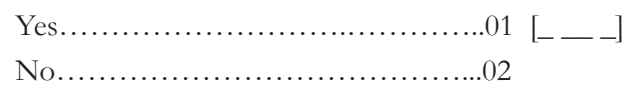

\section{INS: CHECK IF Q 114= '00’ NOT WORKING, THEN ASK Q 118 to Q 120}

118 If not working, since how long are you not working?

Instructions: Enter in months

119 What is the reason for not working? Instructions: Do not read out answers

What is your average monthly household income?

What is your spouse/regular partner's age?

Instructions:

Enter 95 if participant does not have a partner

Is your current spouse/partner employed/ working for pay?

What is the highest level of education of your spouse/partner?

Instructions: For education enter completed school years

from 1 to 12, add one year for each year of university education
Months

Never worked $.995[-\ldots$

Don't want to work $01[-\mid[]$

Lost job due to HIV

Too sick to carry on working...........03

Don't need to work ...................04

Never worked ........................05

Couldn't find job.....................06

Other (specify) ......................88

Yes $01\left[-\mid \_\right]$

No....................................02

Self. $.01[-\mid[]$

Spouse..............................02

Parents.............................03

Siblings............................ 04

Others (specify) ....................88

Amount in Rupees

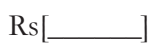

Age in years__ [_/_] If 95 skip to Q201

N/A $\ldots \ldots \ldots \ldots \ldots \ldots \ldots \ldots \ldots \ldots . \ldots 95$

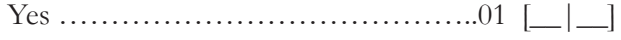

No $\ldots \ldots \ldots \ldots \ldots \ldots \ldots \ldots \ldots \ldots \ldots \ldots . . . \ldots 2$

Illiterate ............................00

Completed years of education

No formal education, but can read and [_- _ $]$

write............................. 77 


\section{SECTION II: HIV TESTING}

Now, I would like to ask you a few questions about why you decided to come in to this clinic for HIV testing and about your experiences in receiving your HIV test results.

\begin{tabular}{|c|c|c|c|c|}
\hline QID & Question & Response options/codes & $\begin{array}{l}\text { Coded } \\
\text { response }\end{array}$ & $\begin{array}{l}\text { Skip } \\
\text { pattern }\end{array}$ \\
\hline 201 & Who referred you to this ICTC? & 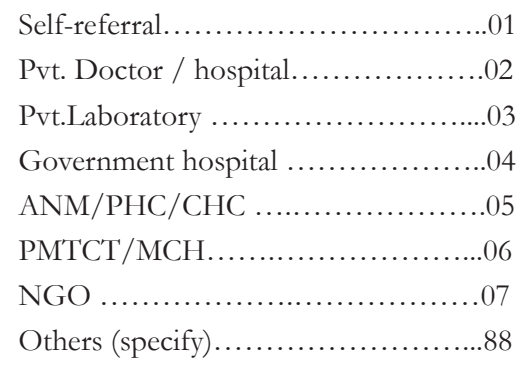 & [_l_ $]$ & \\
\hline 202 & $\begin{array}{l}\text { Why did you want to undertake a HIV test? } \\
\text { Instructions: } \\
\text { - Mark all that apply } \\
\text { - Ask for more reasons, but do not read out } \\
\text { - Enter } 01 \text { if mentioned } \\
\text { - Enter } 02 \text { if not mentioned } \\
\text { Also record Verbatim below }\end{array}$ & 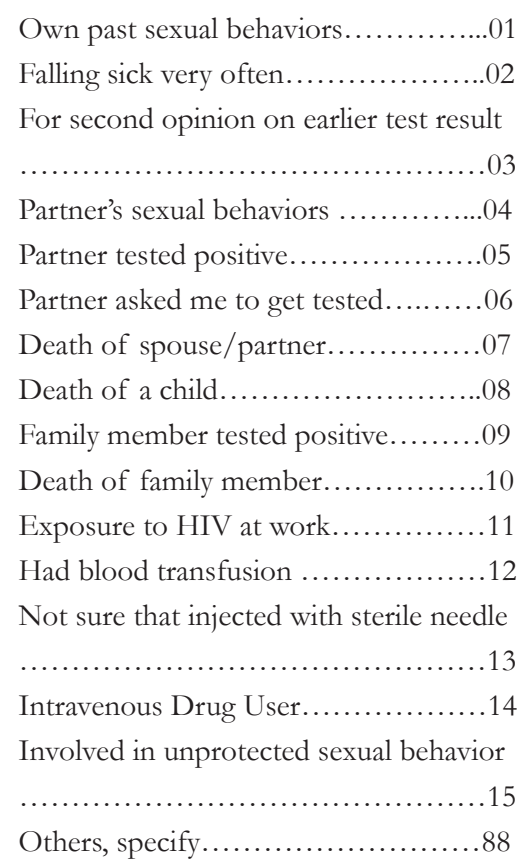 & 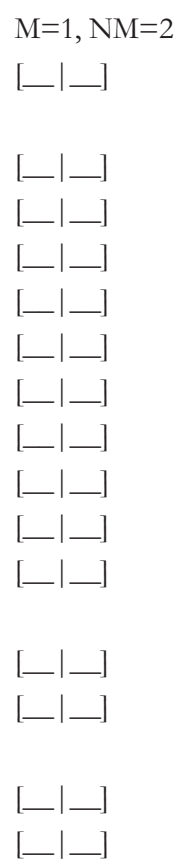 & \\
\hline & Verbatim account: & & & \\
\hline 203 & $\begin{array}{l}\text { How many times have you been tested for } \\
\text { HIV including this current test? }\end{array}$ & Number of HIV tests_ & {$[-\mid \ldots]$} & \\
\hline 204 & $\begin{array}{l}\text { How long did you think about HIV testing } \\
\text { before you decided to be tested for the first } \\
\text { time? } \\
\text { Instructions: } \\
\text { Refer to this test if this is the first, Enter in days }\end{array}$ & Number of days & [_- $]$ & \\
\hline
\end{tabular}




\begin{tabular}{|c|c|c|c|c|}
\hline QID & Question & Response options/codes & $\begin{array}{l}\text { Coded } \\
\text { response }\end{array}$ & $\begin{array}{l}\text { Skip } \\
\text { pattern }\end{array}$ \\
\hline 205 & $\begin{array}{l}\text { How long back did you have your first HIV } \\
\text { test? } \\
\text { Instructions: Enter } 00 \text { if this is the first test }\end{array}$ & Number of months_ & {$\left[\_\mid \_\right]$} & $\begin{array}{l}\text { If } 00 \text { skip } \\
\text { to Q207 }\end{array}$ \\
\hline 206 & $\begin{array}{l}\text { Where did you undergo your first HIV test? } \\
\text { Instructions: Do not read out categories }\end{array}$ & 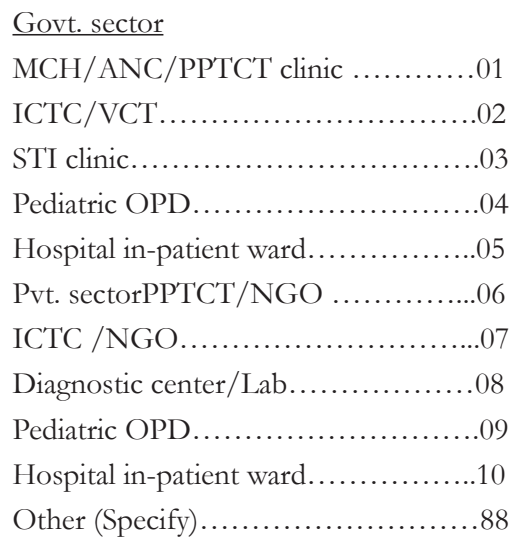 & & \\
\hline 207 & What was the test result at the first time? & 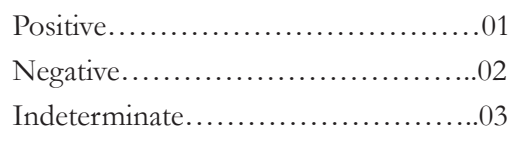 & {$[-\mid[]$} & \\
\hline 208 & $\begin{array}{l}\text { Is today the day of your appointment to } \\
\text { collect your test result? }\end{array}$ & 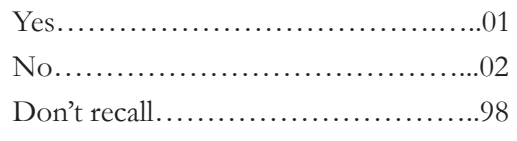 & {$\left[-\mid \_\right]$} & $\begin{array}{l}\text { If 'Yes' skip } \\
\text { to Q210 }\end{array}$ \\
\hline 209 & $\begin{array}{l}\text { By how many days did you delay collecting } \\
\text { your test results? } \\
\text { Instructions: } \\
\text { Enter number of days beyond the date of appointment }\end{array}$ & $\begin{array}{l}\text { Number of Days } \\
\text { Don't recall........................98 }\end{array}$ & {$\left[-\mid \_\right]$} & \\
\hline 210 & Who accompanied you to this ICTC today? & 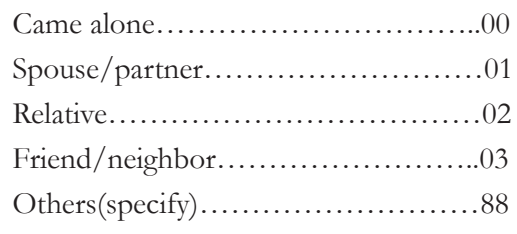 & {$\left[-\mid \_\right]$} & \\
\hline 211 & $\begin{array}{l}\text { Have you told your spouse/partner about } \\
\text { your going for HIV test? }\end{array}$ & 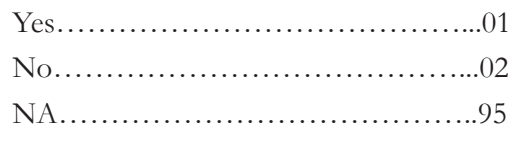 & {$[-1 \ldots]$} & $\begin{array}{l}\text { If no/NA } \\
\text { skip to next } \\
\text { section }\end{array}$ \\
\hline 212 & $\begin{array}{l}\text { Was your partner supportive of your getting } \\
\text { tested for HIV? }\end{array}$ & 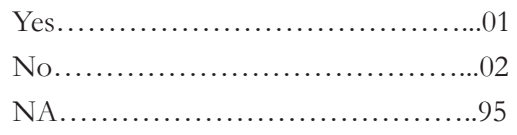 & {$\left[-\mid \_\right]$} & \\
\hline
\end{tabular}




\section{SECTION III: QUALITY OF COUNSELLING AND SERVICES AT ICTC}

Now I am going to ask you questions about the quality of the services that you have received here, at this ICTC, today

\begin{tabular}{|c|c|}
\hline QID & Question \\
\hline 301 & $\begin{array}{l}\text { How long did you wait to see the counsell } \\
\text { today? }\end{array}$ \\
\hline 302 & Did you have a prior appointment? \\
\hline \multirow[t]{10}{*}{303} & Before your blood/sample was taken for \\
\hline & testing at this ICTC, did a health care \\
\hline & provider or counsellor do the following: \\
\hline & Instructions: \\
\hline & - Read out each option \\
\hline & - Enter codes as follows: \\
\hline & Yes.................. \\
\hline & No.......... \\
\hline & No response..............97 \\
\hline & Don't recall................98 \\
\hline
\end{tabular}

304 How much time did the counsellor spend with you prior to your HIV test? Instruction: Refers to pre-test counselling

305 After giving you your test results, did health care provider do the following: Instructions:

$\begin{array}{lll}\text { Response options/codes } & \begin{array}{l}\text { Coded } \\ \text { response }\end{array} & \begin{array}{l}\text { Skip } \\ \text { pattern }\end{array}\end{array}$
Less than 30 minutes.
30-60 minutes.
61-90 minutes

[-

91-120 minutes

More than 120 minutes....

Yes.

No.

Explain that you had a choice to agree to the test or refuse the test...............01 [_|_]

Tell you that your results would not be shared with anyone except for the clinic staff responsible for your care.........02 [_/_]

Explain how the test works.............03 [_/_] Explain that the test does not always detect a very recent HIV infection (window period) ....................04 [_- _] Explain how HIV is transmitted........05 [_l_] Give you advice on preventing the spread of HIV .....................06 [_l_] Give you time to ask questions........07 [_ _ _ ]

Time (in minutes) $\quad[\ldots \mid \ldots$

Explain the meaning of the test result .................................01 [_/_]

Recommend that your sexual partner(s)

be tested for HIV. $02[-\mid$

Read out each option

- Enter codes as follows:

Yes........................01

No......................02

No response...............97

Don't recall.................98

Recommend that your children to be tested for HIV $.03[-1 \ldots]$

Discuss how to prevent the transmission of HIV ........................... [_। Condom demonstration................05 [_|_] Explain about ART ..................06 [_|_] CD4 test............................ [_|_]

Gave referral slip to ART center........08 [_|_] 


\begin{tabular}{|c|c|c|c|c|}
\hline QID & Question & Response options/codes & $\begin{array}{l}\text { Coded } \\
\text { response }\end{array}$ & $\begin{array}{l}\text { Skip } \\
\text { pattern }\end{array}$ \\
\hline & & 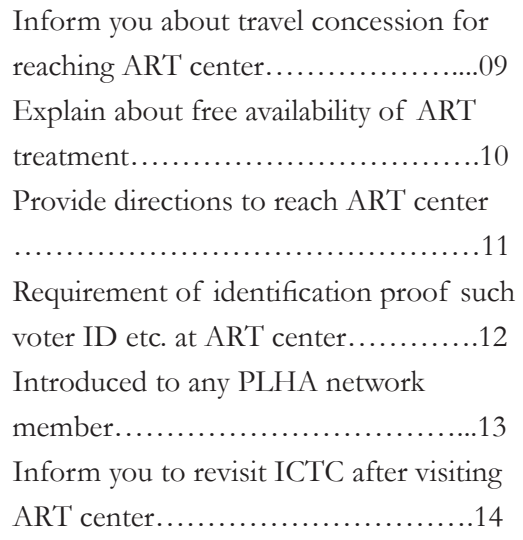 & $\begin{array}{l}{[\ldots \mid \ldots]} \\
{\left[-\mid \_\right]} \\
{\left[\ldots \mid \_\right]} \\
\text {as ration card, } \\
{[\ldots \mid \ldots]} \\
{\left[-\mid \_\right]} \\
{[\ldots \mid \ldots]}\end{array}$ & \\
\hline 306 & $\begin{array}{l}\text { How much time did the counsellor spend } \\
\text { with you after your testing? } \\
\text { Instruction: Refers to post-test counselling }\end{array}$ & Time (in minutes) & {$[-\mid \ldots]$} & \\
\hline 307 & $\begin{array}{l}\text { After giving you your test results, did health } \\
\text { worker talk to you about how to share your } \\
\text { status with people around you, e.g. your } \\
\text { spouse/partner or other family members? }\end{array}$ & 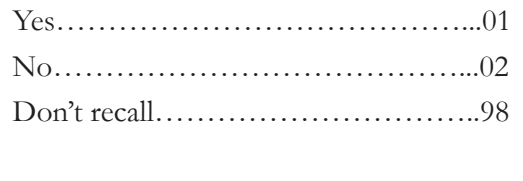 & {$[-1 \ldots]$} & \\
\hline 308 & $\begin{array}{l}\text { Did the counsellor give you information } \\
\text { about NGOs that provide: Nutrition support, } \\
\text { Legal assistance, PLHA networks? } \\
\text { Instructions: } \\
\text { - Read out responses/options }\end{array}$ & 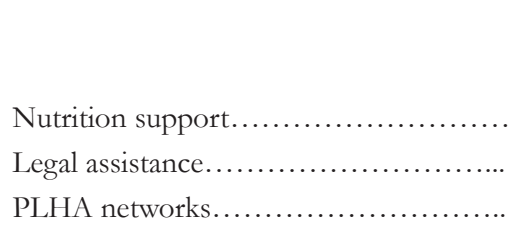 & $\begin{array}{l}\text { Yes }=01 \\
\text { No=02 } \\
{[-\mid-]} \\
{[-\mid-]} \\
{[-\mid-]}\end{array}$ & \\
\hline 309 & $\begin{array}{l}\text { Was counselling done in: } \\
\text { Instructions: } \\
\text { - Read out responses/options } \\
\text { - Enter codes as follows: } \\
\text { Enter } 01 \text { if Yes, enter } 02 \text { if No }\end{array}$ & $\begin{array}{l}\text { A room with a closed door............01 } \\
\text { A cabin separated by cloth or wooden } \\
\text { wall.................................02 } \\
\text { A space where the discussion could not } \\
\text { be heard by anyone outside...........03 } \\
\text { A space where you were not visible to } \\
\text { anyone outside........................04 }\end{array}$ & $\begin{array}{l}\text { Yes }=01 \\
\mathrm{No}=02 \\
{\left[\_\mid \_\right]} \\
{\left[\_\mid \_\right]} \\
{\left[\_\mid \_\right]} \\
{\left[\_\mid \_\right]}\end{array}$ & \\
\hline 310 & $\begin{array}{l}\text { Did you feel that you were counselled in } \\
\text { privacy? }\end{array}$ & 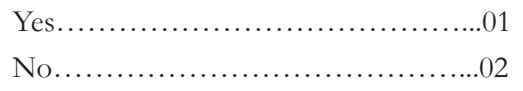 & {$\left[-\mid \_\right]$} & \\
\hline 311 & $\begin{array}{l}\text { What was the level of interruption - did any } \\
\text { one enter the room during the counselling } \\
\text { session? }\end{array}$ & $\begin{array}{l}\text { No interruption } \ldots \ldots \ldots \ldots \ldots \ldots \ldots \ldots . .01 \\
\text { Some interruption......................02 } \\
\text { A lot of interruption } \ldots \ldots \ldots \ldots \ldots \ldots \ldots . . .63\end{array}$ & {$[-\mid[]$} & \\
\hline
\end{tabular}




\begin{tabular}{ll}
\hline QID & Question \\
\hline $312 \quad$ Did the counsellor listen attentively to what \\
& you had to say?
\end{tabular}

313 Was the counsellor in a hurry to end counselling session?

Response options/codes

$\begin{array}{ll}\text { Coded } & \text { Skip } \\ \text { response } & \text { pattern }\end{array}$

Counsellor was attentive. ..01 [_ _ ]

Counsellor was somewhat attentive....02

Counsellor was not attentive. ..03

Counsellor was in a hurry. ..01 [-

Counsellor was in somewhat of a hurry

......................................02

Counsellor was not in a hurry..........03

314 Did the counsellor encourage you to ask questions?

Counsellor encouraged questions.......01 [_|_]

Counsellor somewhat encouraged

questions.......

Counsellor did not encourage questions

................................. 03

315 Did you find the counsellor friendly, sympathetic?

Yes. 01 [_- _ $]$

Somewhat............................02

No...............................03

316 Did the counsellor criticize your or your spouse's sexual or injecting behaviors?

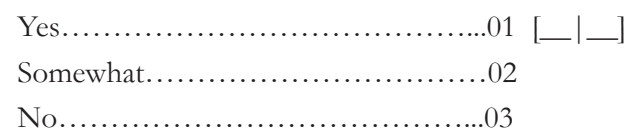

317 How satisfied are you with the counselling services?

Very dissatisfied... $.01[-1 \ldots]$

Dissatisfied..........................02

Neither satisfied nor dissatisfied........03

Satisfied..............................04

Very satisfied.........................05

How many times did you have to come to this

Number of times testing center to get your HIV test done? once, skip to Q320

319 What was the reason for making multiple trips for your HIV test?

Counsellor not present.................01 [_|_]

Lab technician on leave.................02

Told to meet doctor...................03

Kits/supplies out of stock.............04

Visited after working hours.............05

Others (specify) $\ldots \ldots \ldots \ldots \ldots \ldots \ldots \ldots . . . . . .18$

320 Did you have to make many trips to this

Yes............................... [_|_]

If no skip

No. .02

to Q322 


\begin{tabular}{|c|c|c|c|c|}
\hline QID & Question & Response options/codes & $\begin{array}{l}\text { Coded } \\
\text { response }\end{array}$ & $\begin{array}{l}\text { Skip } \\
\text { pattern }\end{array}$ \\
\hline 321 & $\begin{array}{l}\text { Why did you have to make many trips to } \\
\text { collect your test result? }\end{array}$ & 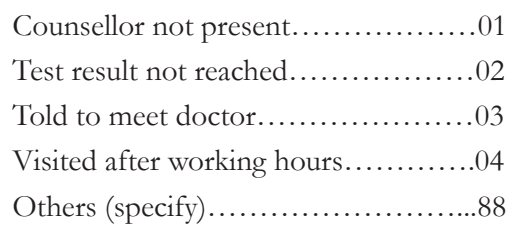 & & \\
\hline 322 & $\begin{array}{l}\text { Did you have to pay anything at ICTC for } \\
\text { your tests? }\end{array}$ & 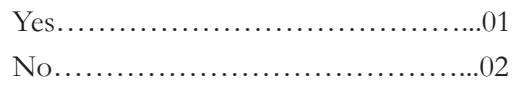 & {$\left[-\mid \_\right]$} & $\begin{array}{l}\text { If No skip } \\
\text { to Q401 }\end{array}$ \\
\hline 323 & If yes, how much did you have to pay? & Amount in Rupees & {$[\square]$} & \\
\hline 324 & $\begin{array}{l}\text { Did you face any problems in getting tested } \\
\text { for HIV or in getting your test results? If yes, } \\
\text { please explain. } \\
\text { Instructions: Record verbatim }\end{array}$ & & & \\
\hline
\end{tabular}




\section{SECTION IV: ACCESS TO ICTCS}

\begin{tabular}{ll}
\hline QID & Question \\
\hline $401 \quad \begin{array}{l}\text { From whom did you learn about this testing } \\
\text { center (ICTC)? }\end{array}$ \\
$402 \quad \begin{array}{l}\text { Approximately, how many kilometers is this } \\
\text { testing center (ICTC) from your place of } \\
\text { residence? } \\
\text { Instruction: Enter distance in kilometers }\end{array}$
\end{tabular}

How did you travel to this facility?

\begin{tabular}{|c|c|}
\hline Response options/codes & $\begin{array}{l}\text { Coded } \\
\text { respons }\end{array}$ \\
\hline Doctor................................. & {$[\ldots$} \\
\hline Friends................. & \\
\hline Spouse/partner....................... 03 & \\
\hline Health worker........................04 & \\
\hline Anganwadi worker.....................05 & \\
\hline Hoarding/poster........... & \\
\hline Other (specify) $\ldots \ldots \ldots \ldots \ldots \ldots \ldots \ldots . \ldots 8$ & \\
\hline Distance in Kilometers & \\
\hline Walked.................................. & [_- $]$ \\
\hline Rickshaw............... & \\
\hline Taxi..................... & \\
\hline Own car/transport....................04 & \\
\hline Bus.................. & \\
\hline Train............................... 06 & \\
\hline Other (specify) $\ldots \ldots \ldots \ldots \ldots \ldots \ldots \ldots 8$ & \\
\hline
\end{tabular}

Approx. how long did it take you to get here?

Time in minutes

Instruction: Enter time in minutes

How much did it cost to get here?

Amount in Rupees

Rs.

Instruction: Enter amount in Rupees

Do you know where the government ART

Yes. center, that the counsellor referred you to, is located?

No.

Don't know.

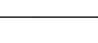

Skip pattern

ponse

Approximately, how many kilometers is the ART center from your place of residence? Instruction: Enter distance in kilometers Enter 99 if does not know

408 When do you plan to visit the ART center that the counsellor referred you to?

Instructions:

If planning to visit within a month, go to Q411

If does not want to visit, go to Q410

$\mathrm{Km}$

Do not Know.

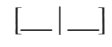

If planning to visit after a month, go to Q409

\begin{tabular}{|c|c|}
\hline Within a week.........................01 [_|_] & If ' 01 or 02 \\
\hline Within a month................... & or 05 ' skip \\
\hline After a month.. & to $\mathrm{Q} 411$ \\
\hline Will not visit.............. & if '04 skip \\
\hline Can't say................................05 & to $\mathrm{Q} 410$ \\
\hline
\end{tabular}




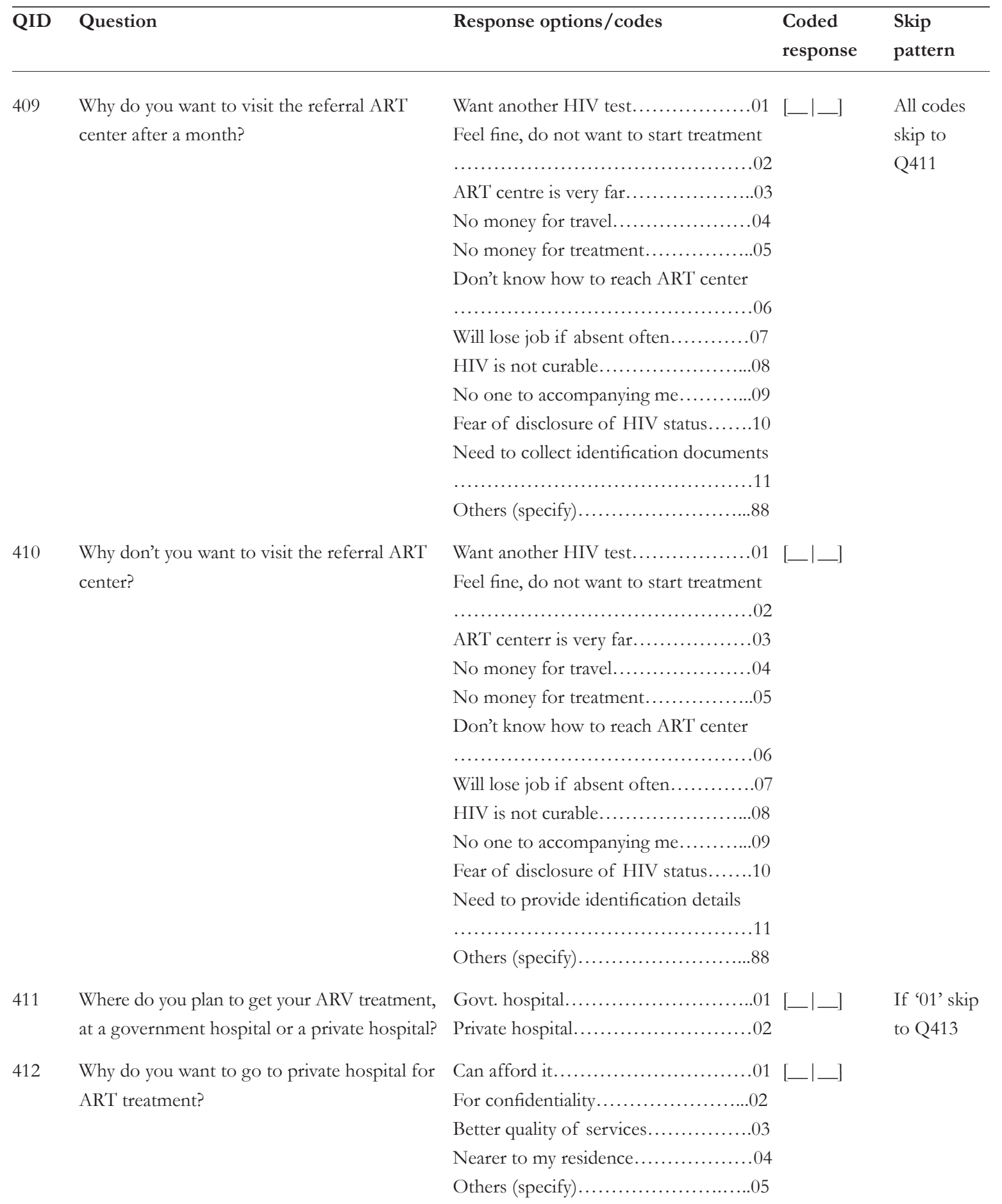




\begin{tabular}{|c|c|c|c|c|}
\hline QID & Question & Response options/codes & $\begin{array}{l}\text { Coded } \\
\text { response }\end{array}$ & $\begin{array}{l}\text { Skip } \\
\text { pattern }\end{array}$ \\
\hline \multirow[t]{6}{*}{413} & The last time you were sick and consulted a & 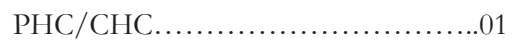 & & \\
\hline & health worker, where did you go for treatment & Government hospital.................02 & & \\
\hline & (general care and not ART)? & Pvt. Doctor/Hospital..................03 & & \\
\hline & Instruction: & Traditional healer/Vaidh...............04 & & \\
\hline & Refers to general medical care - not ART & Homeopathic practitioner..............05 & & \\
\hline & & Others (specify) $\ldots \ldots \ldots \ldots \ldots \ldots \ldots \ldots . \ldots 8$ & {$[-\mid[]$} & \\
\hline \multirow[t]{3}{*}{414} & For common illnesses do you usually first try & $\ldots \ldots \ldots \ldots \ldots .01$ & & \\
\hline & home remedies before consulting an & .............02 & & \\
\hline & allopathic doctor? & & {$\left[\_\mid \_\right]$} & \\
\hline \multirow[t]{4}{*}{415} & How often do you use traditional treatments & $\ldots \ldots \ldots \ldots \ldots \ldots . .01$ & & \\
\hline & from an ayurvedic, unani, homeopathic or & $\ldots \ldots \ldots \ldots \ldots \ldots 2$ & & \\
\hline & vaidhic practitioner when you fall ill -- always, & Never..............................03 & & \\
\hline & sometimes or never? & & {$\left[\_\mid \_\right]$} & \\
\hline
\end{tabular}

End time: ......

\section{Thank you for participating!}




\section{Annex 4. Informed consent for follow-up interview of ICTC patients registering and not registering at ART centers}

\section{Purpose of the study}

(Greet the man/woman). My name is

The Population Council is con-

ducting a study to learn more about the problems

HIV- positive persons face in receiving care and treatment. This study is being supported by the NACO

(National AIDS Control Organization), $\mathrm{MOH} \& \mathrm{FW}$, Government of India. NACO will use this information to improve HIV testing and treatment services for HIV positive persons. Your participation in this study will help NACO to improve the quality of services for you and other people who need treatment for HIV infection.

You were asked for consent to interview while you visited ICTC for counseling. At that time we had asked your consent to be interviewed again in another 3 months. I am once again asking your consent to be interviewed, in private by one of our trained interviewers. The questions will be about your experience in getting treatment, the quality of services at ART centers, how you feel with treatment or reasons for not starting treatment.

\section{Benefits and Risks}

If you agree, your participation will help organizations like the ART centers and its staff in addressing PLHA's needs more efficiently. Some of the questions that you will be asked may be sensitive or personal in nature and perhaps make you uncomfortable. The interviewer will not insist on answers to all questions. Your participation in the study may not benefit you directly. You or your family will not be deprived of any services if you withdraw from participation in this study.

A counsellor is available at any time you would like to receive counsellor's services; either during the interview or after the interview or any other time.

In case someone may have learned of your HIV status when the research team contacted you for the second interview, and you need assistance you can contact the ART counsellor.

\section{Compensation}

You will receive Rs 100 towards reimbursement of transport costs.

\section{Offer to answer questions and freedom to withdraw from the study}

You can refuse to respond to any question and can stop the interview at any time. You and your family will receive all services, if you decide to drop out of the study. The interview will take approximately 15 minutes. Participation is completely voluntary.

\section{Confidentiality}

Everything that you report during the interview will be kept strictly confidential and your name will not be recorded on the questionnaire. All records of your interviews and data collected from medical records will be kept in a safe place under lock and key. These will be destroyed after the completion of the study. 


\section{Subject's Statement}

I have read the consent document regarding my participation in the study / the consent document regarding my participation in the study has been read out to me. I have read or have been read the above considerations regarding my participation in the study. I have been given a chance to ask any questions

I agree to be in this study as a volunteer.

Name of the subject

Signature of the subject:

Signature of a witness:
I may have and my questions have been answered to my satisfaction.

I understand that all records will be kept private, will be destroyed after the study and that I can leave the study at any time. My decision not to be in this study or to leave the study will not affect the services I will receive.

Date:

Date: 


\section{Annex 5. Understanding the factors affecting enrollment of PLHAs into ART services in India}

Follow-up Survey

\begin{tabular}{|c|c|c|c|}
\hline \multicolumn{4}{|c|}{ Interview to be conducted at ART center or in the community } \\
\hline \multicolumn{4}{|l|}{ Subject ID } \\
\hline Sex: & 1 Male & 2. Female & [___] \\
\hline Interview siteART Center & 1. Vijayawada & 4. Satara & 7. Imphal \\
\hline \multirow[t]{3}{*}{ [_l_ $]$} & 2. Rajahmundry & 5. Bijapur & 8. Varanasi \\
\hline & 3. Kolhapur & 6. Bagalkot & 9. Jaipur \\
\hline & & & 10. Mehasana \\
\hline \multirow[t]{4}{*}{ District [_l_] } & 1. Krishna & 4. Satara & 7. Imphal \\
\hline & 2. East Godavari & 5. Bijapur & 8. Varanasi \\
\hline & 3. Kolhapur & 6. Bagalkot & 9. Jaipur \\
\hline & & & 10. Mehasana \\
\hline \multirow[t]{3}{*}{ State $\left[\_l \_\right]$} & 1. Andhra Pradesh & 3. Karnataka & 5. Uttar Pradesh \\
\hline & 2. Maharashtra & 4. Manipur & 6. Rajasthan \\
\hline & & & 7. Gujarat \\
\hline Date on the referral slip & $\mathrm{DD} / \mathrm{MM} / \mathrm{YY}$ & {$\left[-|-|-|-|-\mid \_\right]$} & \\
\hline Reference slip number & & {$\left[-|-|-|-|-\mid \_\right]$} & \\
\hline Referred from ICTC code & 1. Nandigama & 11. Phaltan & 21. Bishenpur \\
\hline \multirow[t]{9}{*}{ [_l_] } & 2. Gudivada & 12. Patan & 22. Azamgarh \\
\hline & 3. Mylavaram & 13. Indi & 23. Bhadoi \\
\hline & 4. Gokavaram & 14. Bagewadi & 24. Jaunpur \\
\hline & 5. Mandapeta & 15. Muddebihal & 25. Sikar \\
\hline & 6. Kadiam & 16. Jamakhandi & 26. Ajmer \\
\hline & 7. Gadingal & 17. Badami & 27. Alwar \\
\hline & 8. Ichalkarauji & 18. Mudhol & 28. Palanpur \\
\hline & 9. Kagal & 19. RIMS, Imphal & 29. Patan, Gujarat \\
\hline & 10. Karad & 20. MLSS, Imphal & 30. Kadi \\
\hline Research Interviewer & Name: & Signature: & \\
\hline Status of Data Collection & 1. Completed & 2. Refused & 3. Incomplete \\
\hline [_l_] & & & \\
\hline
\end{tabular}




\section{SECTION I: BACKGROUND CHARACTERISTICS \\ All participants complete this section}

\begin{tabular}{|c|c|c|c|c|}
\hline QID & Question & Response options/codes & $\begin{array}{l}\text { Coded } \\
\text { response }\end{array}$ & $\begin{array}{l}\text { Skip } \\
\text { pattern }\end{array}$ \\
\hline 101 & $\begin{array}{l}\text { How many people aged } 0-17 \text { are in the } \\
\text { household }\end{array}$ & $\begin{array}{l}\text { Enter ' } 00 \text { ' if None. Enter ' } 05 \text { ' if } 5 \text { and } \\
\text { above }\end{array}$ & {$\left[-\mid \_\right]$} & \\
\hline 102 & What is the household's principal occupation? & 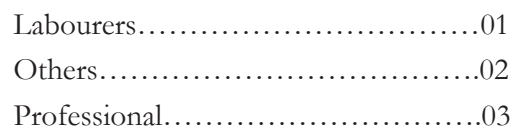 & {$[-\mid[]$} & \\
\hline 103 & $\begin{array}{l}\text { Is the residence all pucca (burnt bricks, stone, } \\
\text { cement, stone, tiles, and jackboard/cement } \\
\text { plastered reeds, timber, galvanized tin or } \\
\text { asbestos cement sheets)? }\end{array}$ & 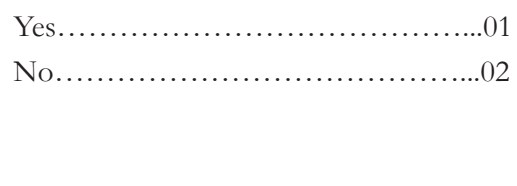 & {$[-\mid \ldots]$} & \\
\hline 104 & $\begin{array}{l}\text { What is the household's primary source of } \\
\text { energy for cooking? }\end{array}$ & 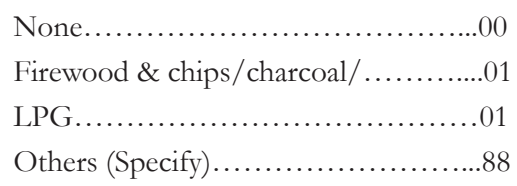 & {$[-\mid[]$} & \\
\hline 105 & Does the household own a television? & 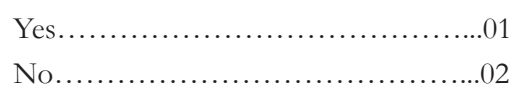 & {$\left[\_\mid \ldots\right]$} & \\
\hline 106 & $\begin{array}{l}\text { Does the household own a bicycle, scooter or } \\
\text { motorcycle? }\end{array}$ & 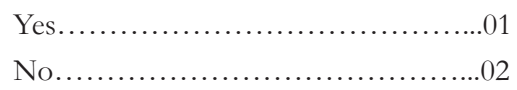 & {$[-\mid \ldots]$} & \\
\hline 107 & $\begin{array}{l}\text { Does the household own an almirah/dressing } \\
\text { table? }\end{array}$ & 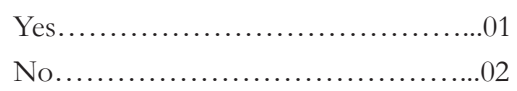 & {$[-\mid[]$} & \\
\hline 108 & Does the household own a sewing machine? & 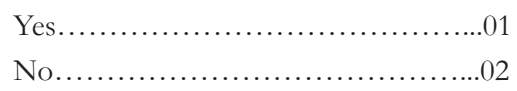 & {$[-\mid[]$} & \\
\hline 109 & $\begin{array}{l}\text { How may pressure cookers or pressure pans } \\
\text { does the household own? }\end{array}$ & 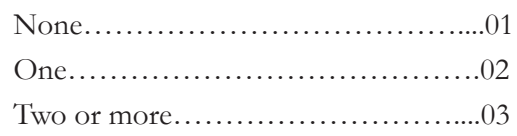 & {$\left[-\mid \_\right]$} & \\
\hline 110 & $\begin{array}{l}\text { How many electric fans does the household } \\
\text { own? }\end{array}$ & 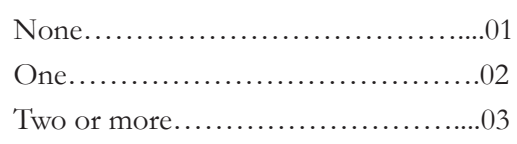 & {$\left[\_\mid \ldots\right]$} & \\
\hline 111 & Does the household own agricultural land? & $\begin{array}{l}Y e s \ldots \ldots \ldots \ldots \ldots \ldots \ldots \ldots \ldots \ldots \ldots \ldots \ldots \ldots \\
\text { No } \ldots \ldots \ldots \ldots \ldots \ldots \ldots \ldots \ldots \ldots \ldots \ldots \ldots \ldots\end{array}$ & {$[-\mid \ldots]$} & \\
\hline
\end{tabular}




\begin{tabular}{|c|c|c|c|c|}
\hline QID & Question & Response options/codes & $\begin{array}{l}\text { Coded } \\
\text { response }\end{array}$ & $\begin{array}{l}\text { Skip } \\
\text { pattern }\end{array}$ \\
\hline 112 & $\begin{array}{l}\text { What is your average monthly household } \\
\text { income? }\end{array}$ & Amount..... & Rs........../- & \\
\hline 113 & $\begin{array}{l}\text { Who is the primary earning member in your } \\
\text { household? }\end{array}$ & 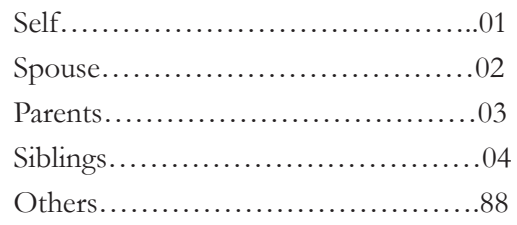 & {$\left[-\mid \_\right]$} & \\
\hline
\end{tabular}




\section{SECTION II: CLIENTS REGISTERED AT THE ART CENTER (Interview conducted at ART Center)}

\begin{tabular}{|c|c|c|c|c|}
\hline QID & Question & Response options/codes & $\begin{array}{l}\text { Coded } \\
\text { response }\end{array}$ & $\begin{array}{l}\text { Skip } \\
\text { pattern }\end{array}$ \\
\hline 201 & $\begin{array}{l}\text { When were you tested for HIV at the ICTC? } \\
\text { Instruction: Verify from referral slip }\end{array}$ & Date of test & & \\
\hline 202 & $\begin{array}{l}\text { When did you collect your test results from } \\
\text { that ICTC? }\end{array}$ & Date of collecting result & & \\
\hline 203 & $\begin{array}{l}\text { Did you undertake another HIV test after the } \\
\text { test at the ICTC center where we interviewed } \\
\text { you? }\end{array}$ & 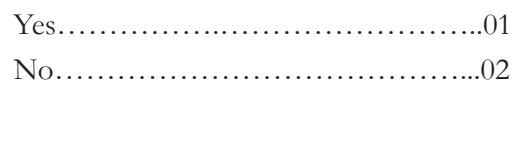 & {$\left[-\mid \_\right]$} & $\begin{array}{l}\text { If No skip } \\
\text { to Q205 }\end{array}$ \\
\hline 204 & $\begin{array}{l}\text { How many additional HIV tests have you } \\
\text { undertaken? }\end{array}$ & Number ------------- & {$\left[-\mid \_\right]$} & \\
\hline 205 & $\begin{array}{l}\text { Has your spouse/partner been tested for } \\
\text { HIV? }\end{array}$ & 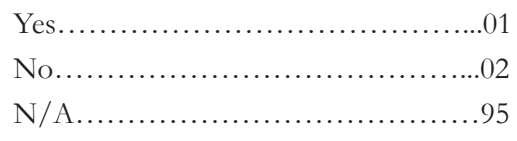 & {$\left[-\mid \_\right]$} & $\begin{array}{l}\text { If No or } \\
\text { N/A skip } \\
\text { to Q208 }\end{array}$ \\
\hline 206 & $\begin{array}{l}\text { When was your spouse/partner tested for } \\
\text { HIV - - before or after your test result? }\end{array}$ & $\begin{array}{l}\text { Before my result......................01 } \\
\text { After my result......................02 } \\
\text { Same time along with my test..........03 }\end{array}$ & {$[-\mid \ldots]$} & \\
\hline 207 & $\begin{array}{l}\text { What is your spouse's/regular partner's HIV } \\
\text { status? }\end{array}$ & 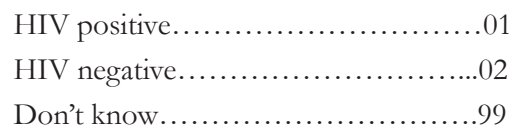 & {$[-\mid \ldots]$} & \\
\hline 208 & $\begin{array}{l}\text { How many biological children do you have? } \\
\text { Instruction: } \\
\text { Enter } 00 \text { if none; enter } 95 \text { if never married/single }\end{array}$ & 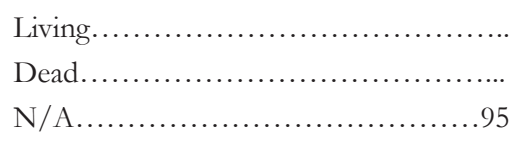 & $\begin{array}{l}{[-\mid-]} \\
{[-\mid-]} \\
{[-\mid-]}\end{array}$ & $\begin{array}{l}\text { If } \mathrm{N} / \mathrm{A} \\
\text { skip to } \\
\text { Q212 }\end{array}$ \\
\hline 209 & $\begin{array}{l}\text { How many of your biological children have } \\
\text { been tested for HIV? } \\
\text { Instruction: } \\
\text { Include only living children } \\
\text { Enter } 00 \text { if none, Enter } 95 \text { if child died, Enter } 99 \\
\text { if don't know }\end{array}$ & 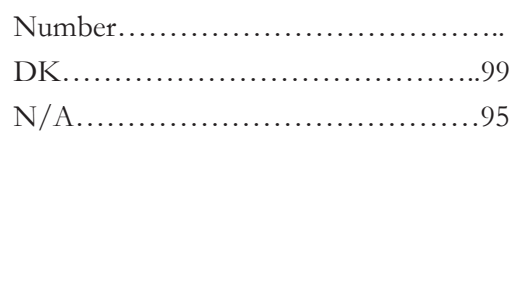 & [_|_] & $\begin{array}{l}\text { If no or } \\
\text { DK skip } \\
\text { Q212 }\end{array}$ \\
\hline 210 & $\begin{array}{l}\text { When was the child (were the children) tested } \\
\text { for HIV, before or after your test? }\end{array}$ & $\begin{array}{l}\text { Before my result......................01 } \\
\text { After my result.......................02 } \\
\text { Same time along with my test.........03 }\end{array}$ & {$[-\mid \ldots]$} & \\
\hline
\end{tabular}




\begin{tabular}{|c|c|c|c|c|}
\hline QID & Question & Response options/codes & $\begin{array}{l}\text { Coded } \\
\text { response }\end{array}$ & $\begin{array}{l}\text { Skip } \\
\text { pattern }\end{array}$ \\
\hline \multirow[t]{6}{*}{211} & Please tell me how many of your children are & Number............. & {$\left[\_\mid \_\right]$} & \\
\hline & HIV +ve? & Do not know.........................99 & {$[\ldots$} & \\
\hline & Instruction: & & & \\
\hline & Include only living children & & & \\
\hline & Enter 00 if none of the living children are positive & & & \\
\hline & Enter 99 if don't know & & & \\
\hline
\end{tabular}

Now I would like to ask you a few questions related to your visit (s) to the ART center, the treatment you have received and your views about ART services

\begin{tabular}{|c|c|c|c|}
\hline 212 & When was your first visit to this ART Center? & Date of first visit & 1 \\
\hline 213 & When did you register at this ART center? & Date of registration & \\
\hline 214 & $\begin{array}{l}\text { Have you ever received ART prior to } \\
\text { registering at this ART center? }\end{array}$ & 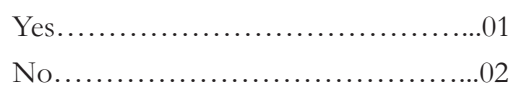 & \\
\hline 215 & From where did you obtain ART treatment? & 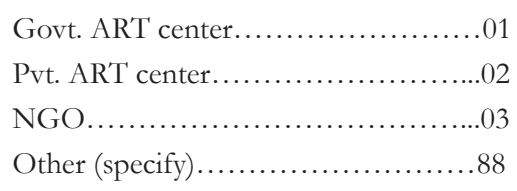 & $\begin{array}{l}{[-\mid-]} \\
{[-\mid-]} \\
{[-\mid-]} \\
{[-\mid-]}\end{array}$ \\
\hline 216 & How long did you take ART treatment? & Duration in Months & {$\left[-\left|\_\right| \_\right]$} \\
\hline 217 & $\begin{array}{l}\text { On an average, how much money did you } \\
\text { spend per month for ART treatment? }\end{array}$ & Amount in Rupees................... & Rs........./- \\
\hline 218 & $\begin{array}{l}\text { [Check Q202. For respondents who registered at the } \\
\text { ART center more than one month after collecting } \\
\text { HIV test result] } \\
\text { What was the main reason for taking more } \\
\text { than a month to register at this ART center? } \\
\text { Instruction: } \\
\text { Do not read out the options } \\
\text { Also record verbatim }\end{array}$ & 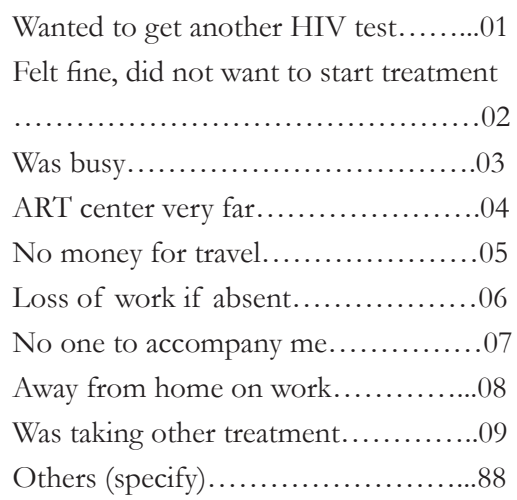 & {$\left[-\mid \_\right]$} \\
\hline
\end{tabular}

Verbatim account: 


\begin{tabular}{|c|c|c|c|c|}
\hline QID & Question & Response options/codes & $\begin{array}{l}\text { Coded } \\
\text { response }\end{array}$ & $\begin{array}{l}\text { Skip } \\
\text { pattern }\end{array}$ \\
\hline \multirow[t]{10}{*}{219} & $\begin{array}{l}\text { [Check Q202, For respondents who registered at the } \\
\text { ART center within one month after collecting HIV }\end{array}$ & & $\begin{array}{l}\mathbf{M}=1 \\
\mathrm{NM}=2\end{array}$ & \\
\hline & test result] & Counsellor/ Doctor referred............01 & {$[-1 \ldots]$} & \\
\hline & $\begin{array}{l}\text { What prompted you to register at this ART } \\
\text { center within one month? }\end{array}$ & $\begin{array}{l}\text { Afraid of HIV/AIDS disease...........02 } \\
\text { PLHA network member accompanied }\end{array}$ & {$\left[-\mid \_\right]$} & \\
\hline & Instruction: & 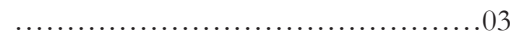 & {$[-1 \ldots]$} & \\
\hline & Do not read out the options & Was sick/hospitalised.................04 & {$\left[\ldots \mid \_\right]$} & \\
\hline & Enter 1 if mentioned, Enter 2 if not mentioned & Friends suggested.....................05 & {$\left[-\mid \_\right]$} & \\
\hline & Also record verbatim & $\begin{array}{l}\text { Located in the same place where HIV } \\
\text { tested } \ldots \ldots \ldots \ldots \ldots \ldots \ldots \ldots \ldots \ldots \ldots \ldots \ldots \ldots \ldots\end{array}$ & {$[\quad 1]$} & \\
\hline & & Easy accessible......... & {$[-1 \ldots]$} & \\
\hline & & Others (specify) $\ldots \ldots \ldots \ldots \ldots \ldots \ldots \ldots . \ldots . \ldots 1$ & {$\left[-\mid \_\right]$} & \\
\hline & Verbatim account: & & & \\
\hline \multirow[t]{2}{*}{220} & At this time have you registered at any other & Yes...................................01 & & If no skip \\
\hline & government or private or NGO ART center? & No................................. & & to $\mathrm{Q} 223$ \\
\hline \multirow[t]{6}{*}{221} & Where all have you registered for ART services? & & $\mathbf{M}=1$ & \\
\hline & Instruction: & & $\mathbf{N M}=2$ & \\
\hline & Do not read out the options & Govt. ART center....................01 & {$\left[\_\mid \_\right]$} & \\
\hline & Enter 1 if mentioned, & Pvt. ART center........................02 & {$\left[\_\mid \_\right]$} & \\
\hline & Enter 2 if not mentioned] & 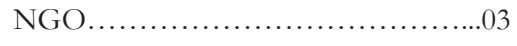 & {$\left[\_\mid \_\right]$} & \\
\hline & Write the name(s) of center(s) on dotted line & Other (specify) $\ldots \ldots \ldots \ldots \ldots \ldots \ldots \ldots$ & {$[-\mid[]$} & \\
\hline \multirow[t]{11}{*}{222} & [if more than one ART center] & & $\mathbf{M}=1$ & \\
\hline & Why have you registered at more than one & & $\mathbf{N M}=2$ & \\
\hline & ART center? & Quality of medicine...................01 & {$\left[\_\mid \_\right]$} & \\
\hline & Instruction: & Quality of services....................02 & {$\left[\_\mid \_\right]$} & \\
\hline & Enter 1 if mentioned, Enter 2 if not mentioned & Availability of free medicine...........03 & {$\left[\_\mid \_\right]$} & \\
\hline & Also record verbatim & Nearer to place of residence...........04 & {$\left[-\mid \_\right]$} & \\
\hline & & Treatment is good.....................05 & {$\left[-\mid \_\right]$} & \\
\hline & & No crowd............................06 & {$[-1 \ldots]$} & \\
\hline & & 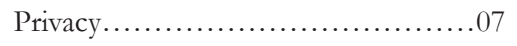 & {$[-1 \ldots]$} & \\
\hline & & Belief that confidentiality will be & & \\
\hline & & 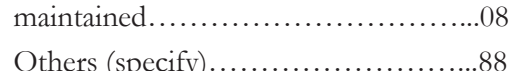 & {$[-\mid-]$} & \\
\hline
\end{tabular}

Verbatim account:

Yes.....................................01 [_l_]

No................................02
If no skip

to Q225 


\begin{tabular}{|c|c|c|c|c|}
\hline QID & Question & Response options/codes & $\begin{array}{l}\text { Coded } \\
\text { response }\end{array}$ & $\begin{array}{l}\text { Skip } \\
\text { pattern }\end{array}$ \\
\hline 224 & $\begin{array}{l}\text { How much did you pay when you consulted } \\
\text { ayurvedic/unani or other vaidhs? }\end{array}$ & 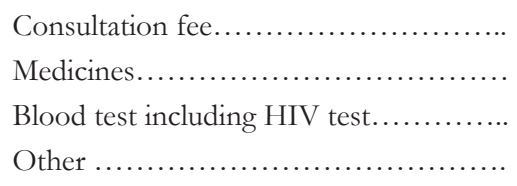 & $\begin{array}{l}\text { Rs. ...../- } \\
\text { Rs. ...../- } \\
\text { Rs. ...../- } \\
\text { Rs. ...../- }\end{array}$ & \\
\hline 225 & $\begin{array}{l}\text { After your HIV test at the ICTC, did you } \\
\text { consult a private allopathic practitioner? }\end{array}$ & 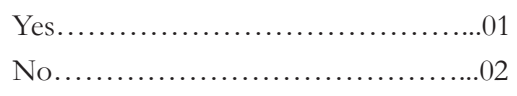 & [- & $\begin{array}{l}\text { If no skip } \\
\text { to Q227 }\end{array}$ \\
\hline 226 & $\begin{array}{l}\text { How much did you pay when you consulted a } \\
\text { private allopathic practitioner? }\end{array}$ & 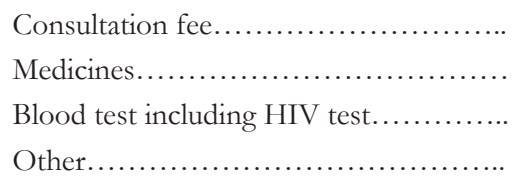 & $\begin{array}{l}\text { Rs. ...../- } \\
\text { Rs. ...../- } \\
\text { Rs. ...../- } \\
\text { Rs. ...../ }\end{array}$ & \\
\hline 227 & $\begin{array}{l}\text { After your HIV test at the ICTC, have you } \\
\text { had a CD4 blood test to see if you need to } \\
\text { start ART for your HIV infection? }\end{array}$ & 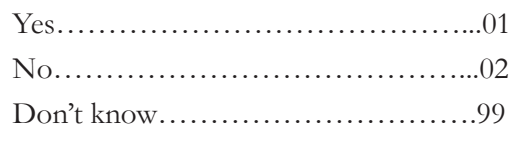 & {$[-\mid[]$} & $\begin{array}{l}\text { If no skip } \\
\text { to Q231 }\end{array}$ \\
\hline 228 & Where was the CD4 test undertaken? & 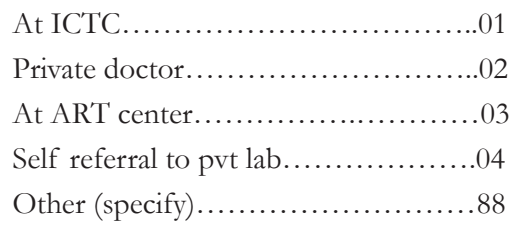 & {$\left[-\mid \_\right]$} & \\
\hline 229 & How much did you pay for your CD4 test? & Amount................................... & Rs........./- & \\
\hline 230 & $\begin{array}{l}\text { What was your CD4 count? } \\
\text { Instruction: } \\
\text { Enter } 99 \text { if don't know }\end{array}$ & 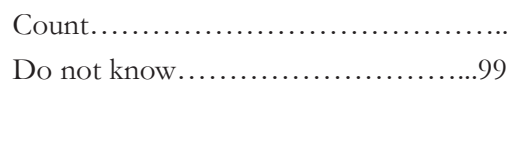 & {$\left[-\left|\_\right| \_\right]$} & \\
\hline 231 & Are you taking ART medications? & 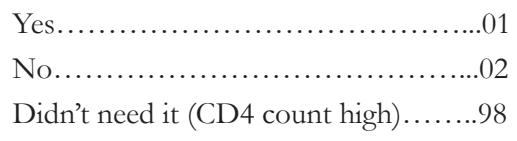 & {$[-\mid[]$} & $\begin{array}{l}\text { If no/don't } \\
\text { need skip to } \\
\text { Q233 }\end{array}$ \\
\hline 232 & $\begin{array}{l}\text { Where do you get your ART medications? } \\
\text { Instruction: } \\
\text { Do not read out options } \\
\text { Enter } 1 \text { if mentioned, Enter } 2 \text { if not mentioned }\end{array}$ & 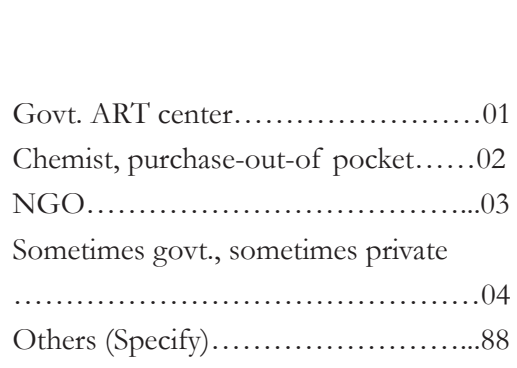 & $\begin{array}{l}\mathbf{M}=1 \\
\mathbf{N M}=2 \\
{\left[-\mid \_\right]} \\
{\left[-\mid \_\right]} \\
{\left[-\mid \_\right]} \\
{\left[-\mid \_\right]} \\
{\left[-\mid \_\right]}\end{array}$ & \\
\hline
\end{tabular}




\begin{tabular}{l} 
QID Question \\
\hline $233 \quad$ After your HIV test at the ICTC, did anyone \\
advise you to seek HIV treatment/ART from \\
a private practitioner: \\
a. Private allopathic doctor? \\
b. A private non-allopathic doctor like \\
ayurvedic or unani?
\end{tabular}

Do they receive treatment at this ART center?

What was the reason for making more than one trip to this ART center before registration? Instruction:

Do not read out options

Enter 1 if mentioned, Enter 2 if not mentioned

Did the ICTC counsellor provide the
Response options/codes

Coded
response

Skip pattern
No one........................... a) [_

Self.............................. b) [_| $]$

PLHA advised........................03

Family members advised...............04

Tout/agent/dalal/middle man advised

.......................................05

Others (specify) $\ldots \ldots \ldots \ldots \ldots \ldots \ldots \ldots . \ldots 8$

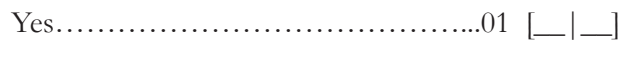

No...............................02

Yes..................................01 [_|]

No....................................02

Vaidhic, unani or homeopathic for your HIV infection?

Please tell me how many of your family members are receiving ART treatment?

Instruction:

Family includes only spouse and biological children

Number

[IF NONE ENTER '00’]

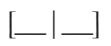

If ' 00 ' skip

to Q238

Yes.

$01[-\mid[]$

No

I would now like to ask you some questions about your experience at this center

How many times did you visit this ART center before you were registered?

Number of visits

[_l_ $]$

If only once skip to Q240

$\mathbf{M}=1$

$\mathrm{NM}=2$

Counsellor not available..

Lab technician not available.

Doctor not available.

Had to wait for CD4 counts.

Asked to repeat HIV test....

Medications out of stock. .06 [_- _ ]

Long queues. .07 [_- _ ]

Put on a waiting list. .08 [_/_]

Others (specify).... .88 [_- _ ] following to reach the ART center?

Yes.

01 a) $[-\mid \ldots]$

No. .02 b)

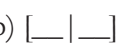

a. Referral Slip

b. Directions 


\begin{tabular}{|c|c|c|c|c|}
\hline QID & Question & Response options/codes & $\begin{array}{l}\text { Coded } \\
\text { response }\end{array}$ & $\begin{array}{l}\text { Skip } \\
\text { pattern }\end{array}$ \\
\hline 241 & Who accompanied you to this ART center? & 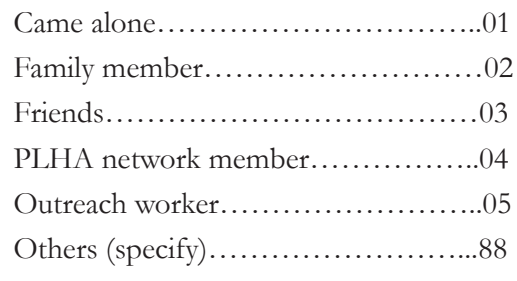 & {$[-1-]$} & $\begin{array}{l}\text { If PLHA } \\
04 \text { go to } \\
\text { Q242, else } \\
\text { skip to } \\
\text { Q243 }\end{array}$ \\
\hline 242 & $\begin{array}{l}\text { Were you introduced to the PLHA network } \\
\text { member at the ICTC? }\end{array}$ & 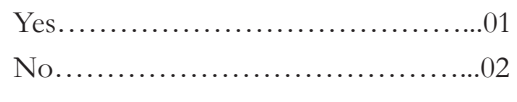 & {$\left[-\mid \_\right]$} & \\
\hline 243 & $\begin{array}{l}\text { Please tell me: } \\
\text { Instruction: } \\
\text { Enter } 01 \text { if Yes, } 02 \text { if No }\end{array}$ & 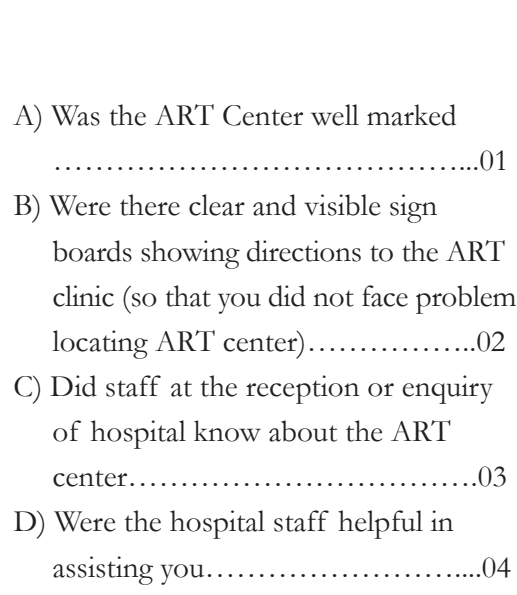 & {$[-\mid-]$} & \\
\hline 244 & How did you travel to ART center? & 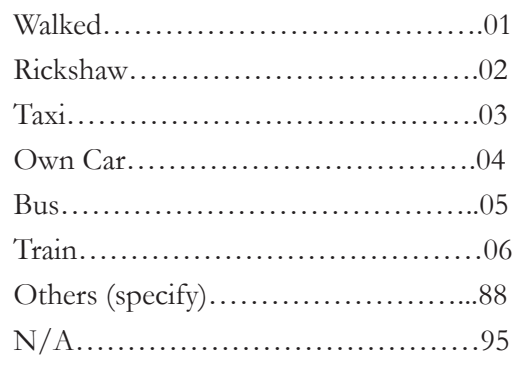 & {$[-\mid[]$} & \\
\hline 245 & $\begin{array}{l}\text { Approx. how long did it take you to get to } \\
\text { ART center today? }\end{array}$ & Duration in Minutes & {$\left[-\left|\_\right| \ldots\right]$} & \\
\hline 246 & $\begin{array}{l}\text { How much does it cost, on an average, to } \\
\text { travel once to the ART center? }\end{array}$ & Amount in Rupees & Rs.........../- & \\
\hline 247 & $\begin{array}{l}\text { Did anyone inform you about bus or rail } \\
\text { travel concession for HIV patients? }\end{array}$ & $\begin{array}{l}\text { Yes, Bus concession...................01 } \\
\text { Yes, Rail concession....................02 } \\
\text { No } \ldots \ldots \ldots \ldots \ldots \ldots \ldots \ldots \ldots \ldots \ldots \ldots \ldots \ldots \ldots \ldots \ldots \ldots \ldots \ldots\end{array}$ & $\begin{array}{l}{[-\mid-]} \\
{[-\mid-]}\end{array}$ & $\begin{array}{l}\text { If no skip } \\
\text { to Q249 }\end{array}$ \\
\hline
\end{tabular}




\begin{tabular}{|c|c|c|c|c|}
\hline QID & Question & Response options/codes & $\begin{array}{l}\text { Coded } \\
\text { response }\end{array}$ & $\begin{array}{l}\text { Skip } \\
\text { pattern }\end{array}$ \\
\hline 248 & Who informed about travel concession? & 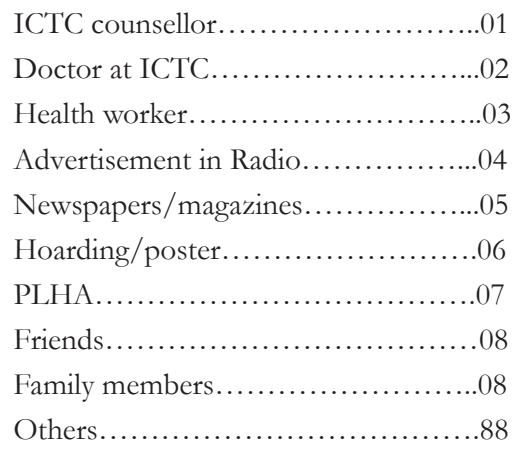 & {$\left[-\mid \_\right]$} & \\
\hline 249 & $\begin{array}{l}\text { What is the distance to the ART center from } \\
\text { your residence? }\end{array}$ & Distance in $\mathrm{Km} . . . \ldots \ldots \ldots . . .$. & {$[---]$} & \\
\hline 250 & $\begin{array}{l}\text { What were the problems you faced in } \\
\text { reaching here? } \\
\text { [Record Verbatim] }\end{array}$ & & & \\
\hline 251 & $\begin{array}{l}\text { Did you have to pay anything for your } \\
\text { treatment and tests at this ART center? }\end{array}$ & 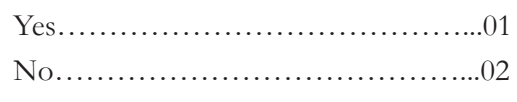 & {$\left[\_\mid \ldots\right]$} & $\begin{array}{l}\text { If no skip } \\
\text { to Q253 }\end{array}$ \\
\hline 252 & $\begin{array}{l}\text { If Yes, how much did you pay for the } \\
\text { following services? } \\
\text { Instructions: Read out options }\end{array}$ & $\begin{array}{l}\text { A) Registration } \\
\text { B) ARV medicines } \\
\text { C) OI medicines } \\
\text { D) Radiology-X-rays } \\
\text { E) Blood tests including HIV test } \\
\text { F) Nutritional supplements } \\
\text { G) Unani/Ayurveda/homeo medicines }\end{array}$ & $\begin{array}{l}\text { Rupees } \\
\text { A. [- }[--] \\
\text { B. [-- ] } \\
\text { C. [-- ] } \\
\text { D. [-- ] } \\
\text { E. [- }[--] \\
\text { F. [- }[--] \\
\text { G. [-- ] }\end{array}$ & \\
\hline 253 & $\begin{array}{l}\text { How much did you spend on HIV related } \\
\text { treatment in the last month? } \\
\text { Instructions: } \\
\text { Read out options } \\
\text { Refers to total expense for each category in the last } \\
\text { month }\end{array}$ & $\begin{array}{l}\text { A) Registration } \\
\text { B) ARV medicines } \\
\text { C) OI medicines } \\
\text { D) Radioloy-X-rays } \\
\text { E) Blood tests including HIV test } \\
\text { F) Nutritional supplements } \\
\text { G) Unani/Ayurveda/homeo medicines }\end{array}$ & $\begin{array}{l}\text { Rupees } \\
\text { A. [-- ] } \\
\text { B. [-- ] } \\
\text { C. [- }[--] \\
\text { D. [-- ] } \\
\text { E. [- }[--] \\
\text { F. [- }[--] \\
\text { G. [-- ] }\end{array}$ & \\
\hline
\end{tabular}

Now I would like to ask few questions related to the counselling services you have received at this ART center.

254 How long did you wait to see counsellor at the ART center?
Less than 30 minutes..................01 [_|_]

30-60 minutes.......................02

61-90 minutes..........................03

91-120 minutes......................04

More than 120 minutes...............05 


\begin{tabular}{|c|c|}
\hline QID & Question \\
\hline 255 & $\begin{array}{l}\text { How much time did the ART counsellor } \\
\text { spend with you? }\end{array}$ \\
\hline \multirow[t]{4}{*}{256} & $\begin{array}{l}\text { Did the ART counsellor discuss the following } \\
\text { with you? }\end{array}$ \\
\hline & Instruction: \\
\hline & Read out each topic \\
\hline & Enter 1 if Yes, Enter 2 if No \\
\hline
\end{tabular}

\begin{tabular}{|c|c|}
\hline Response options/codes & $\begin{array}{l}\text { Coded } \\
\text { respons }\end{array}$ \\
\hline Less than 10 minutes....................01 & {$[-1$} \\
\hline $10-20$ minutes......................... & \\
\hline $20-30$ minutes .......................03 & \\
\hline More than 30 minutes................04 & \\
\hline
\end{tabular}

Mre than 30 minutes...................04

Preventing transmission of HIV .......01
Reduction of risk behaviour............
ART treatment.........................
Nutrition.................................

HIV testing for spouse and children

.................................... 05 [_|

Follow-ups.........................06 [_|_]

Life-long treatment....................07 [_|_]

Treatment adherence...................08 [_|_]

CD4 count eligibility for ART treatment

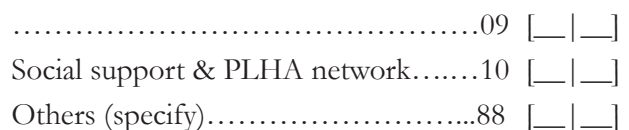

257 How did you find the ART counsellor's

Sympathetic.

$.01\left[-\mid \_\right]$ attitude towards you: sympathetic or not

Not particularly sympathetic.

sympathetic?

Negative.............................03

258 Did you feel that you had enough privacy during your interaction with the counsellor at this ART center? . $.01\left[-\mid \_\right]$

No....................................02

Did the ART counsellor

a. Allow you to ask questions

b. Answer your question and clarify all your doubts?

260 How satisfied are you with ART counsellor's counselling session?

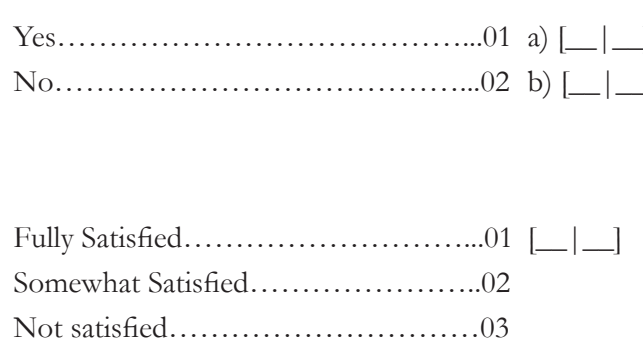

Now I would like to ask few questions related to the medical services you have received at this ART center

261 How long did you wait to see doctor at the ART center?

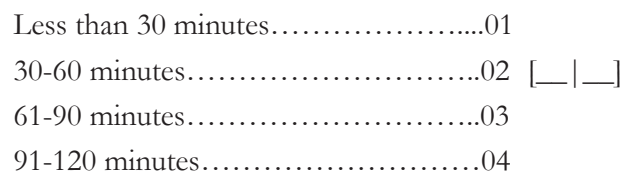

More than 120 minutes................05 


\begin{tabular}{|c|c|c|c|c|}
\hline QID & Question & Response options/codes & $\begin{array}{l}\text { Coded } \\
\text { response }\end{array}$ & $\begin{array}{l}\text { Skip } \\
\text { pattern }\end{array}$ \\
\hline 262 & $\begin{array}{l}\text { How much time did the doctor spend with } \\
\text { you? }\end{array}$ & 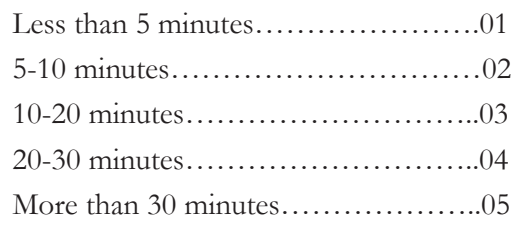 & {$\left[-\mid \_\right]$} & \\
\hline 263 & $\begin{array}{l}\text { Did the doctor discuss the following with } \\
\text { you? } \\
\text { Instruction: } \\
\text { Read out each topic } \\
\text { Enter } 1 \text { if YES, Enter } 2 \text { if NO }\end{array}$ & 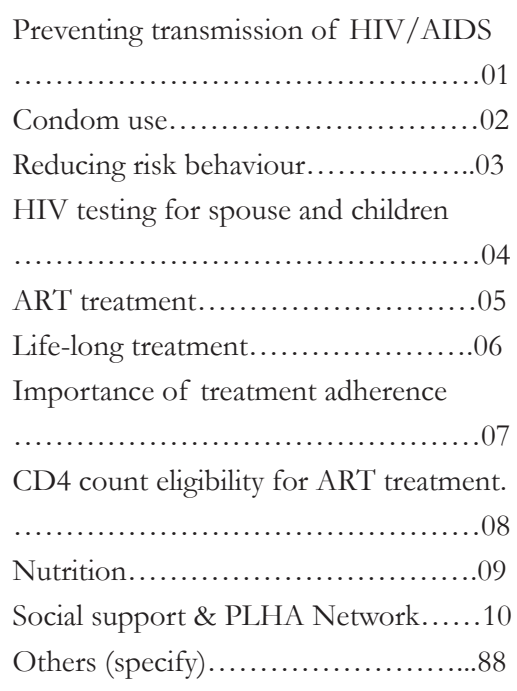 & $\begin{array}{l}\mathrm{Y}=1 \mathrm{NO}=2 \\
{[-\mid-]} \\
{[-\mid-]} \\
{[-\mid-]} \\
{[-\mid-]} \\
{[-\mid-]} \\
{[-\mid-]} \\
{[-\mid[]} \\
{[-\mid-]} \\
{[-\mid-]} \\
{[-\mid-]}\end{array}$ & \\
\hline 264 & $\begin{array}{l}\text { How did you find the doctor's attitude } \\
\text { towards you: sympathetic, not sympathetic? }\end{array}$ & $\begin{array}{l}\text { Sympathetic } \ldots \ldots \ldots \ldots \ldots \ldots \ldots \ldots \ldots . .01 \\
\text { Not particularly sympathetic............02 } \\
\text { Negative.............................. }\end{array}$ & {$[-1 \ldots]$} & \\
\hline 265 & $\begin{array}{l}\text { Did the doctor } \\
\text { a. Allow you to ask questions } \\
\text { b. Answer your questions and clarify all } \\
\text { your doubts? }\end{array}$ & 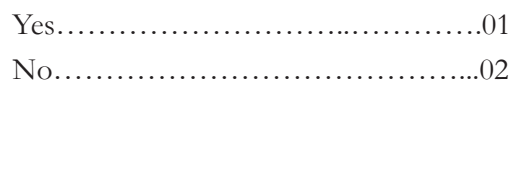 & $\begin{array}{l}\text { a) }[-\mid-] \\
\text { b) }[-\mid-]\end{array}$ & \\
\hline 266 & $\begin{array}{l}\text { How satisfied you are with the doctor's } \\
\text { consultation? }\end{array}$ & $\begin{array}{l}\text { Fully satisfied } \ldots \ldots \ldots \ldots \ldots \ldots \ldots \ldots \ldots \ldots \ldots \\
\text { Partially satisfied } \ldots \ldots \ldots \ldots \ldots \ldots \ldots \ldots \ldots \ldots \\
\text { Not satisfied } \ldots \ldots \ldots \ldots \ldots \ldots \ldots \ldots \ldots \ldots \ldots \ldots\end{array}$ & {$[-\mid[]$} & \\
\hline 267 & $\begin{array}{l}\text { Did anyone inform you about the availability } \\
\text { of free ARV medicines at government ART } \\
\text { centers? }\end{array}$ & 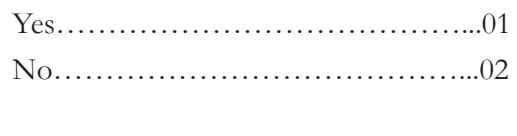 & {$\left[-\mid \_\right]$} & $\begin{array}{l}\text { If no skip } \\
\text { to Q269 }\end{array}$ \\
\hline 268 & $\begin{array}{l}\text { Who informed about the availability of free } \\
\text { ARV medicine at government ART centers? }\end{array}$ & $\begin{array}{l}\text { ICTC counsellor......................01 } \\
\text { Member of PLHA Network...........02 } \\
\text { ART counsellor/Doctor...............03 } \\
\text { Family member........................ } 04 \\
\text { Others (specify) } \ldots \ldots \ldots \ldots \ldots \ldots \ldots \ldots . \ldots 8\end{array}$ & {$\left[-\mid \_\right]$} & \\
\hline
\end{tabular}




\begin{tabular}{|c|c|c|c|c|}
\hline QID & Question & Response options/codes & $\begin{array}{l}\text { Coded } \\
\text { response }\end{array}$ & $\begin{array}{l}\text { Skip } \\
\text { pattern }\end{array}$ \\
\hline 269 & $\begin{array}{l}\text { Were you told to go back to ICTC for follow- } \\
\text { up visit? }\end{array}$ & $\begin{array}{l}Y e s \ldots \ldots \ldots \ldots \ldots \ldots \ldots \ldots \ldots \ldots \ldots \ldots \ldots \ldots \ldots \\
\text { No } \ldots \ldots \ldots \ldots \ldots \ldots \ldots \ldots \ldots \ldots \ldots \ldots \ldots \ldots \ldots \ldots \ldots \ldots \ldots\end{array}$ & {$[-\mid \ldots]$} & \\
\hline 270 & $\begin{array}{l}\text { Were you given any referral slip to hand over } \\
\text { at the ICTC center at the time of return visit? }\end{array}$ & $\begin{array}{l}Y e s \ldots \ldots \ldots \ldots \ldots \ldots \ldots \ldots \ldots \ldots \ldots \ldots \ldots \ldots \ldots \ldots \ldots \ldots \ldots \ldots \ldots \ldots \ldots \ldots \ldots \ldots \ldots \ldots \ldots \ldots \ldots \ldots \ldots \ldots \\
\text { No }\end{array}$ & {$\left[\_\mid-\right]$} & \\
\hline 271 & $\begin{array}{l}\text { Were you told within what time period you } \\
\text { have to go for follow-up to ICTC? }\end{array}$ & 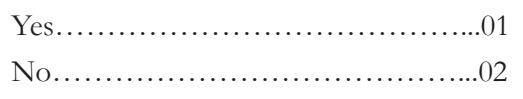 & {$[-\mid \ldots]$} & \\
\hline
\end{tabular}

Now, I would like to ask you few questions related to your Identification information to be provided at ART Center

272 Have you been asked to provide identification information at ART center?

What identification information were you asked to provide at this ART center?

Instruction:

Do not read out the options

Enter 1 if mentioned, Enter 2 if not mentioned
Yes.

No.

$$
\text { (n) }
$$

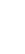

Do you feel 'uncomfortable' in providing the identification information at the ART center?
Providing what identification information made you feel uncomfortable?

Instruction:

Do not read out the options

Enter 1 if mentioned, Enter 2 if not mentioned
Yes

\begin{tabular}{|c|c|c|}
\hline Yes.................................01 & {$[-1 \ldots]$} & If no skip \\
\hline ......02 & & to Q277 \\
\hline & $\mathbf{M}=1$ & \\
\hline & $\mathbf{N M}=2$ & \\
\hline Voter identity card ......................01 & {$\left[\_\mid \_\right]$} & \\
\hline Any other photo identity card..........02 & {$\left[\_\mid \_\right]$} & \\
\hline Ration card..........................03 & {$\left[\_\mid \_\right]$} & \\
\hline Permanent address/affidavit certificate & & \\
\hline$\ldots .04$ & {$[-\mid \ldots]$} & \\
\hline Phone number......................... 05 & {$\left[-\mid \_\right]$} & \\
\hline Contact details of references...........06 & {$\left[-\mid \_\right]$} & \\
\hline Care giver's address and details........07 & {$\left[-\mid \_\right]$} & \\
\hline Others (specify) $\ldots \ldots \ldots \ldots \ldots \ldots \ldots \ldots . \ldots . \ldots . \ldots$ & {$\left[\_\mid \_\right]$} & \\
\hline
\end{tabular}

Voter identity card.......

Other photo identity card...

Ration card......

....01 [_l_ $]$

.02

\section{$\mathrm{M}=1$}

$\mathrm{NM}=2$

Permanent address/affidavit/certificate

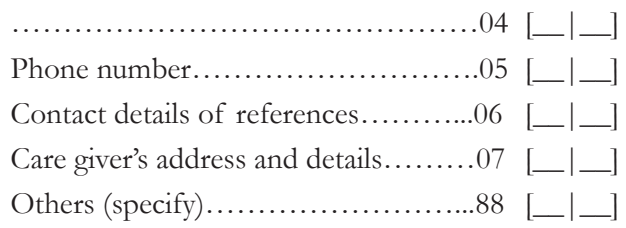

If no skip

to Q275

. $.01\left[-\mid \_\right]$

$.02\left[-\mid \_\right]$

$.03\left[-\mid \_\right]$ 


\begin{tabular}{|c|c|c|c|c|}
\hline QID & Question & Response options/codes & $\begin{array}{l}\text { Coded } \\
\text { response }\end{array}$ & $\begin{array}{l}\text { Skip } \\
\text { pattern }\end{array}$ \\
\hline 276 & $\begin{array}{l}\text { Why were you uncomfortable in providing } \\
\text { identification information at this ART center? } \\
\text { Instruction: } \\
\text { Do not read out the options } \\
\text { Enter } 1 \text { if mentioned, Enter } 2 \text { if not mentioned }\end{array}$ & $\begin{array}{l}\text { Fear of disclosure...................01 } \\
\text { Don't trust the staff at ART center.....02 } \\
\text { Friends would come to know of my } \\
\text { status...............................03 } \\
\text { People would discriminate.............04 } \\
\text { Family members will come to know } \\
\text { about status..........................05 } \\
\text { Fear of misuse of identification } \\
\text { information..........................06 } \\
\text { Others (specify) } \ldots \ldots \ldots \ldots \ldots \ldots \ldots \ldots . \ldots 8\end{array}$ & $\begin{array}{l}\mathbf{M}=1 \\
\mathbf{N M}=2 \\
{\left[-\mid \_\right]} \\
{\left[\_\mid \_\right]} \\
{\left[\_-\ldots\right]} \\
{\left[-\mid \_\right]} \\
{\left[-\mid \_\right]} \\
{\left[-\mid \_\right]} \\
{\left[-\mid \_\right]}\end{array}$ & \\
\hline 277 & $\begin{array}{l}\text { Are you comfortable with an out-reach } \\
\text { worker visiting you at home to verify your } \\
\text { identification information, if required by the } \\
\text { ART center? }\end{array}$ & 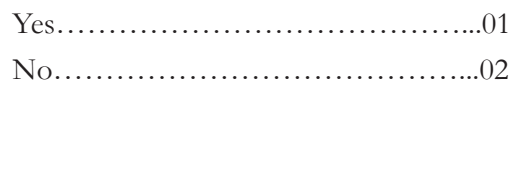 & {$[-\mid[]$} & \\
\hline
\end{tabular}




\section{SECTION III: UNREGISTERED CLIENTS}

(To be interviewed in the community)

This section does apply to clients who registered at referral ART center

\begin{tabular}{|c|c|c|c|c|}
\hline QID & Question & Response options/codes & $\begin{array}{l}\text { Coded } \\
\text { response }\end{array}$ & $\begin{array}{l}\text { Skip } \\
\text { pattern }\end{array}$ \\
\hline \multirow[t]{2}{*}{301} & $\begin{array}{l}\text { When were you tested for HIV at the ICTC? } \\
\text { Instruction: }\end{array}$ & Date of test & & \\
\hline & $\begin{array}{l}\text { Verify from referral slip } \\
\text { If slip not available record month and year }\end{array}$ & Month/Year & --1 & \\
\hline 302 & $\begin{array}{l}\text { When did you collect your test results from } \\
\text { that ICTC? }\end{array}$ & Date of collecting result & & \\
\hline 303 & $\begin{array}{l}\text { Did you undertake another HIV test after the } \\
\text { test at the ICTC center where we interviewed } \\
\text { you? }\end{array}$ & 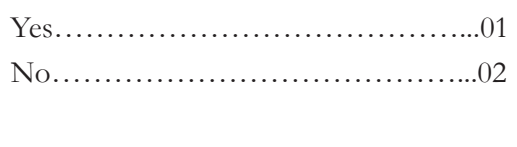 & [_- $]$ & $\begin{array}{l}\text { If No skip } \\
\text { to Q305 }\end{array}$ \\
\hline 304 & $\begin{array}{l}\text { How many additional HIV tests have you } \\
\text { undertaken? }\end{array}$ & Number ------------- & {$[-\mid-]$} & \\
\hline 305 & Has your spouse/partner been tested for HIV? & 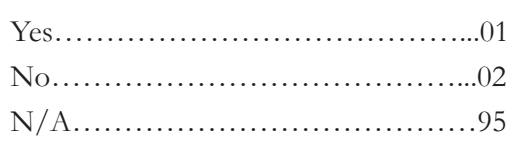 & {$\left[\_\mid \_\right]$} & $\begin{array}{l}\text { IF No or } \\
\text { N/A skip } \\
\text { to Q308 }\end{array}$ \\
\hline 306 & $\begin{array}{l}\text { When was your spouse/partner tested for } \\
\text { HIV -- before or after your test result? }\end{array}$ & $\begin{array}{l}\text { Before my result.....................01 } \\
\text { After my result......................02 }\end{array}$ & {$\left[\_\mid \_\right]$} & \\
\hline 307 & $\begin{array}{l}\text { What is your spouse's/regular partner's HIV } \\
\text { status? }\end{array}$ & $\begin{array}{l}\text { HIV positive } \ldots \ldots \ldots \ldots \ldots \ldots \ldots \ldots \ldots . .01 \\
\text { HIV negative.......................... } 02 \\
\text { Don't know........................ }\end{array}$ & & \\
\hline 308 & $\begin{array}{l}\text { How many biological children do you have? } \\
\text { Instruction: } \\
\text { Enter } 00 \text { if none } \\
\text { Enter } 95 \text { if never married/single }\end{array}$ & $\begin{array}{l}\text { Living................... } \\
\text { Dead.................... } \\
\text { N/A.............................. } 95\end{array}$ & {$\left[-\mid \_\right]$} & $\begin{array}{l}\text { If } \mathrm{N} / \mathrm{A} \\
\text { skip to } \\
\text { Q312 }\end{array}$ \\
\hline 309 & $\begin{array}{l}\text { How many of your biological children have } \\
\text { been tested for HIV? } \\
\text { Instruction: Include only living children } \\
\text { Enter } 00 \text { if none } \\
\text { Enter } 95 \text { if child died } \\
\text { Enter } 99 \text { if don't know }\end{array}$ & 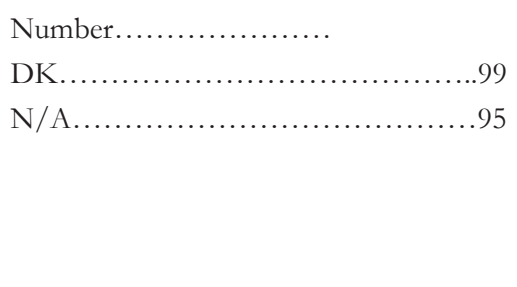 & {$\left[\_\mid \ldots\right]$} & \\
\hline 310 & $\begin{array}{l}\text { When was the child (were the children) } \\
\text { tested for HIV, before or after your test? }\end{array}$ & 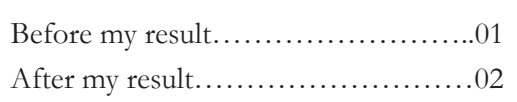 & {$\left[-\mid \_\right]$} & \\
\hline
\end{tabular}




\begin{tabular}{llll}
\hline QID & Question & Response options/codes & $\begin{array}{c}\text { Coded } \\
\text { response }\end{array}$ \\
\hline $311 \quad$ Please tell me how many of your children are & Number................... \\
& HIV positive? & \\
& Instruction: \\
& Enter 00 if none are positive \\
& Enter 99 if don't know
\end{tabular}

Now I would like to ask few questions related to HIV treatment (ART Services)

312 After your HIV test at the ICTC center, have you consulted any doctor about HIV treatment or ART?

Have you registered anywhere for ART services?

Why have you not registered any where for ART services and HIV care?

Instruction:

Also record verbatim
Yes...

No......

Private allopathic doctor.

Government allopathic doctor.........02

Ayurvedic/yunani/vaidh..............03

Others (specify).

.. .88

Yes

No. 01

Wanted to get another HIV tes .02

Felt fine, did not want to start treatment

..................................02

Was busy.

.03

ART center very far.

No money for travel.

Loss of work if absent................06

No one to accompany me.............07

Fear of disclosure.....................08

Family members opposed..............09

Others (specify) $\ldots \ldots \ldots \ldots \ldots \ldots \ldots \ldots . \ldots 8$
Skip

pattern

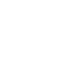




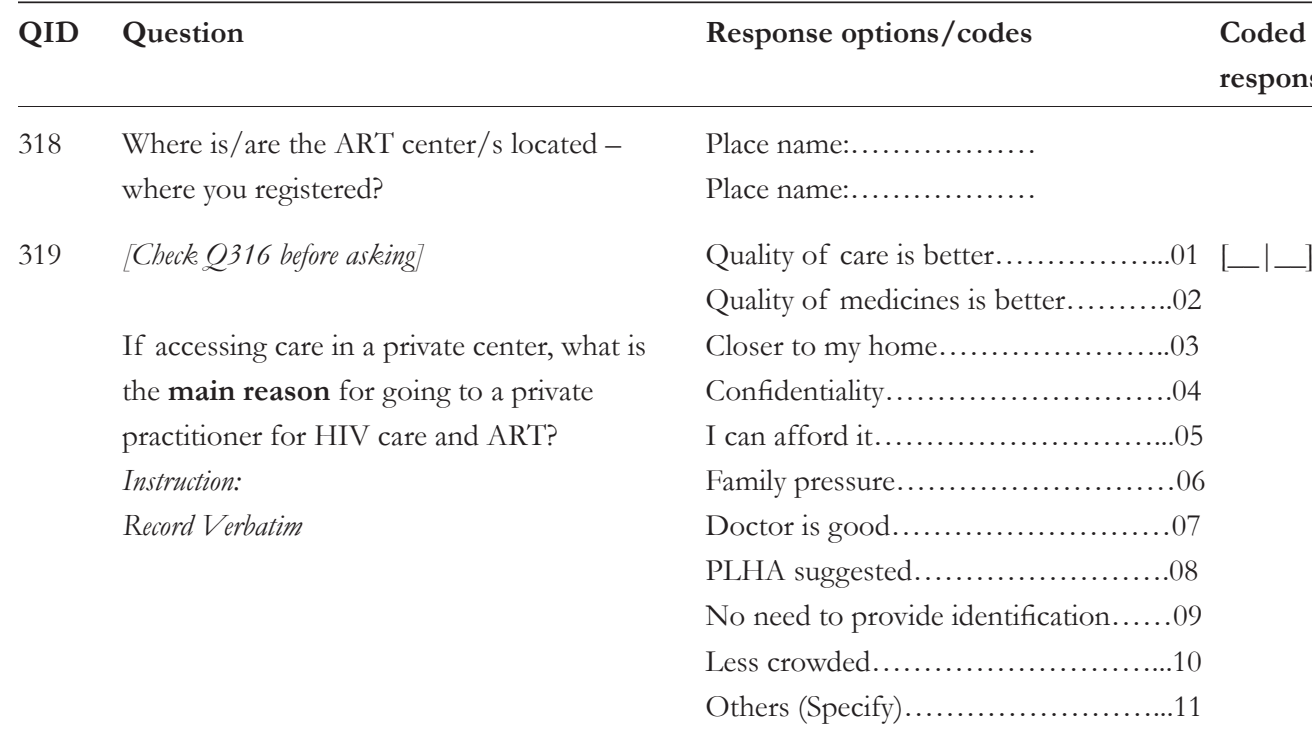

Verbatim account:

320 What was the reason for not registering at the government ART?

Wanted to get another HIV test.

. .01

Felt fine, did not want to start treatment

$\left[\left(\right.\right.$ Check $Q^{316} \neq 1$ OR Q316=1 but not the Concerned ART selected for our study, then ask] ...................................02

Was busy...........................03

ART center very far...................04

No money for travel..................05

[Record Verbatim]

Loss of work if absent...............06

No one to accompany me.............07

No confidentiality....................08

Fear of disclosure as others from my area

take treatment there...................09

Family members opposed.............10

Lost the referral slip...................11

No one told me/no referral provided

....................................02

Don't want to provide identification

details................................13

Too crowded.........................14

Others (specify) .....................88

Verbatim account:

321 After the test at the ICTC did you consult any ayurvedic/unani or other vaidh?
Yes.
..01 [_- _ ]
No.
.02
Consultation fee...
Rs. ...../-
Medicines.....
Rs. ...../-
Blood test including HIV test. ...
Rs. ...../-
Other.
Rs. ...../-

If No skip

to Q323

How much did you pay when you consulted ayurvedic/unani or other vaidh? 


\begin{tabular}{|c|c|c|c|c|}
\hline QID & Question & Response options/codes & $\begin{array}{l}\text { Coded } \\
\text { response }\end{array}$ & $\begin{array}{l}\text { Skip } \\
\text { pattern }\end{array}$ \\
\hline 323 & $\begin{array}{l}\text { After your HIV test at the ICTC, did you } \\
\text { consult a private allopathic practitioner? }\end{array}$ & 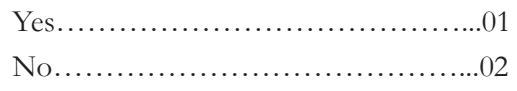 & {$[-1 \ldots]$} & $\begin{array}{l}\text { If no skip } \\
\text { to Q325 }\end{array}$ \\
\hline 324 & $\begin{array}{l}\text { How much did you pay when you consulted a } \\
\text { private allopathic practitioner? }\end{array}$ & 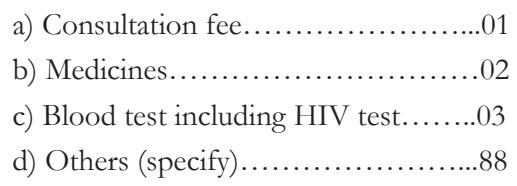 & $\begin{array}{l}\text { Rs. ...../- } \\
\text { Rs. ...../- } \\
\text { Rs. ...../- } \\
\text { Rs. ...../- }\end{array}$ & \\
\hline 325 & $\begin{array}{l}\text { Were you informed about the availability of } \\
\text { free ARV medicine at govt ART centers? }\end{array}$ & 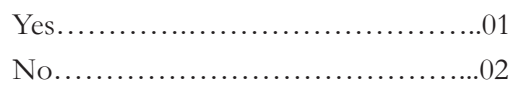 & {$[-\mid[]$} & \\
\hline 326 & $\begin{array}{l}\text { Were you given a referral slip for the ART } \\
\text { center by the counsellor at ICTC center? }\end{array}$ & 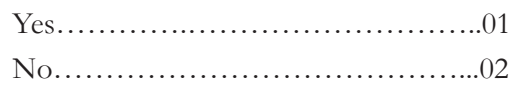 & {$\left[-\mid \_\right]$} & \\
\hline 327 & $\begin{array}{l}\text { Have you had a CD } 4 \text { blood test to see if you } \\
\text { need to start ART for your HIV infection? }\end{array}$ & 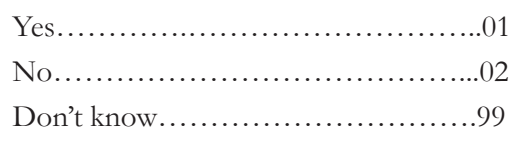 & {$[-\mid[]$} & $\begin{array}{l}\text { If no or } \\
\text { DK skip to } \\
\text { Q332 }\end{array}$ \\
\hline 328 & Where was the CD4 test done? & 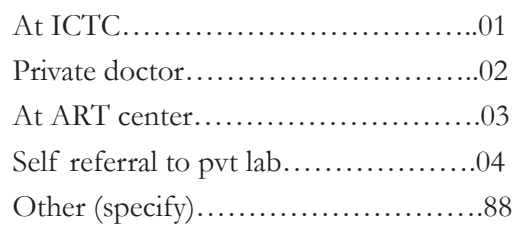 & {$\left[-\mid \_\right]$} & \\
\hline 329 & $\begin{array}{l}\text { What was your CD4 count? } \\
\text { Instruction: } \\
\text { Enter } 999 \text { if don't know }\end{array}$ & 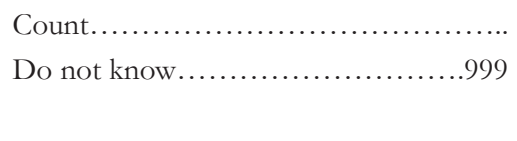 & {$\left[-|-| \_\right]$} & \\
\hline 330 & How much did you pay for your CD4 test? & Amount............... & Rs............./- & \\
\hline 331 & $\begin{array}{l}\text { Did the counsellor at the ICTC inform you } \\
\text { about the need for taking a CD4 blood test? }\end{array}$ & 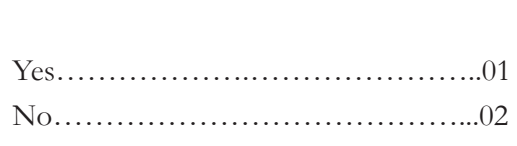 & {$\left[-\mid \_\right]$} & \\
\hline 332 & Are you taking ART medications? & 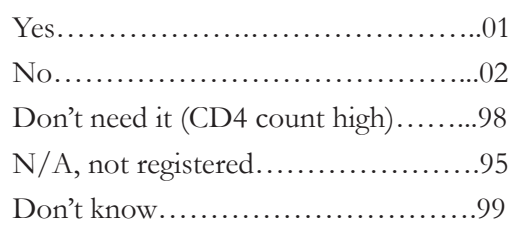 & {$\left[-\mid \_\right]$} & $\begin{array}{l}\text { If not 'yes' } \\
\text { skip to } \\
\text { Q334 }\end{array}$ \\
\hline 333 & $\begin{array}{l}\text { Where do you obtain your ART medications? } \\
\text { Instruction: } \\
\text { Do not read out options }\end{array}$ & $\begin{array}{l}\text { Govt. ART center.....................01 } \\
\text { Chemist, purchase-out-of pocket......02 } \\
\text { NGO...............................03 } \\
\text { Sometimes govt., sometimes private...04 } \\
\text { Others (Specify).......................88 }\end{array}$ & {$\left[-\mid \_\right]$} & \\
\hline
\end{tabular}




$\begin{array}{ll}\text { Coded } & \text { Skip } \\ \text { response } & \text { pattern }\end{array}$

334 How much did you spend on HIV related treatment last month?

Instruction:

Refers to total expense for a month for each category
A) ARV medicines
A. $[---]$
B) OI medicines
B. $[---]$
C) Radiology-X-rays
C. [_- $]$
D) Blood tests
D. $[---]$
E) Nutritional supplements
E. [- - ]
F) Consultation fees
F. [- - ]
G) Other (specify)
G. [-- ]

335 After your HIV test at the ICTC, did anyone

No one advised.

01 a) [advise you to seek HIV treatment/ART from private practitioner?

PLHS advised....

a. Private allopathic doctor?

b. A non-allopathic doctor?

Family members advised.

Unknown persons advised.

Others (specify)....

Did any one inform you that HIV is curable?

Are you taking any other treatments like

Vaidhic, unani or homeopathic for your

Yes. . $.01\left[-\mid \_\right]$

No. . .02 HIV infection?

Please tell me how many of your family members are receiving ART treatment? Instruction:

Family includes only spouse and biological cbildren

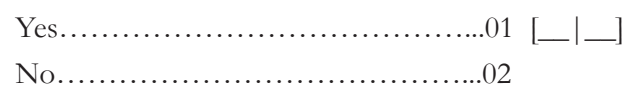

Number.

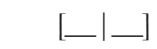

If ' 00 ' skip

$\mathrm{N} / \mathrm{A}$ no family.... . .95 to Q340

N/A no HIV positive family members .95

Where do they get ART medications?

Instruction:

Do not read out options

Enter '01' if mentioned '02' if not mentioned

After your HIV test, did the ICTC counsellor provide the following?

a. Referral Slip for the ART center

b. Directions to reach ART center

Were you introduced to a PLHA network member at the ICTC?

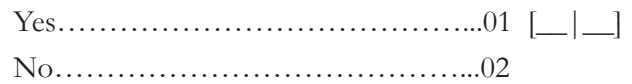

Sometimes govt., sometimes private

Others (Specify) $\ldots \ldots \ldots \ldots \ldots \ldots \ldots \ldots . \ldots 8,\left[\_\right]$

Yes. ..01 a) [_ _ _ $]$

No. ...02 b) [_l_ $]$

No. 


\begin{tabular}{|c|c|c|c|c|}
\hline QID & Question & Response options/codes & $\begin{array}{l}\text { Coded } \\
\text { response }\end{array}$ & $\begin{array}{l}\text { Skip } \\
\text { pattern }\end{array}$ \\
\hline 342 & $\begin{array}{l}\text { Did anyone in the ICTC inform you about } \\
\text { bus or rail travel concession for HIV patients? }\end{array}$ & $\begin{array}{l}\text { Yes, Bus concession...................01 } \\
\text { Yes, Rail concession...................02 } \\
\text { No } \ldots \ldots \ldots \ldots \ldots \ldots \ldots \ldots \ldots \ldots \ldots \ldots \ldots \ldots \ldots \ldots \ldots \ldots \ldots \ldots\end{array}$ & {$\left[-\mid \_\right]$} & \\
\hline 343 & $\begin{array}{l}\text { What is the approximate distance to ART } \\
\text { center from your residence? }\end{array}$ & Distance in $\mathrm{kms}$ & {$[----]$} & \\
\hline 344 & Did you go back to ICTC after testing? & $\begin{array}{c}Y e s \ldots \ldots \ldots \ldots \ldots \ldots \ldots \ldots \ldots \ldots \ldots \ldots \ldots \ldots \\
\text { No } \ldots \ldots \ldots \ldots \ldots \ldots \ldots \ldots \ldots \ldots \ldots \ldots \ldots \ldots \ldots \ldots\end{array}$ & {$\left[\_\mid \_\right]$} & \\
\hline 345 & $\begin{array}{l}\text { Are you comfortable with an out-reach } \\
\text { worker or member of the PLHA network } \\
\text { visiting you at home? }\end{array}$ & 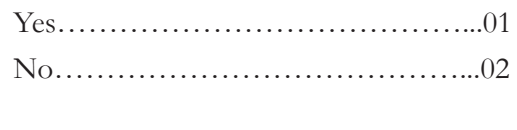 & {$[-1 \ldots]$} & \\
\hline
\end{tabular}


SECTION IV: MESSAGES ON PREVENTION AND TREATMENT SEEKING BEHAVIOUR All participants complete section IV

\begin{tabular}{|c|c|c|c|c|}
\hline QID & Question & Response options/codes & $\begin{array}{l}\text { Coded } \\
\text { response }\end{array}$ & $\begin{array}{l}\text { Skip } \\
\text { pattern }\end{array}$ \\
\hline 401 & $\begin{array}{l}\text { What messages on prevention of HIV } \\
\text { transmission did you receive at the ICTC } \\
\text { center? } \\
\text { Instruction: } \\
\text { Read out each option } \\
\text { Enter } 01 \text { if Yes, } 02 \text { if No }\end{array}$ & 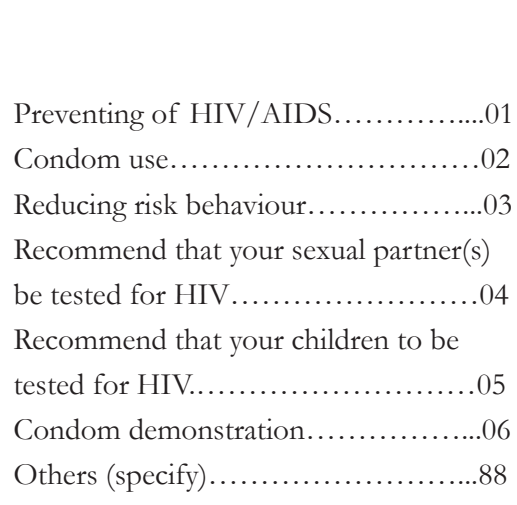 & $\begin{array}{l}\text { Yes=1 } \\
\text { No=2 } \\
{\left[-\mid \_\right]} \\
{\left[-\mid \_\right]} \\
{\left[-\mid \_\right]} \\
{\left[-\mid \_\right]} \\
{\left[-\mid \_\right]} \\
{\left[-\mid \_\right]} \\
{\left[-\mid \_\right]}\end{array}$ & \\
\hline 402 & $\begin{array}{l}\text { How useful were these prevention messages? } \\
\text { Would you say they were: useful, somewhat } \\
\text { useful or not useful? }\end{array}$ & 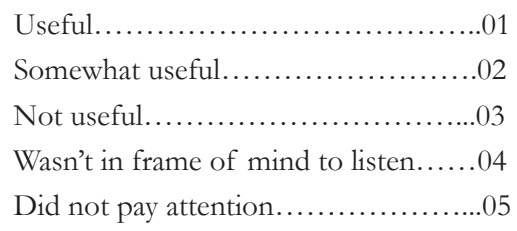 & {$[-\mid[]$} & \\
\hline 403 & $\begin{array}{l}\text { Were you given any printed materials related to } \\
\text { a. Prevention of HIV transmission } \\
\text { b. ART treatment }\end{array}$ & 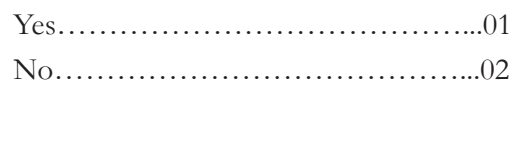 & & $\begin{array}{l}\text { If no to } \\
\text { both skip to } \\
\text { Q406 }\end{array}$ \\
\hline 404 & $\begin{array}{l}\text { What messages did the printed materials } \\
\text { given to you contain? } \\
\text { Instruction: } \\
\text { Read out each option } \\
\text { Enter } 01 \text { if Yes, } 02 \text { if No }\end{array}$ & 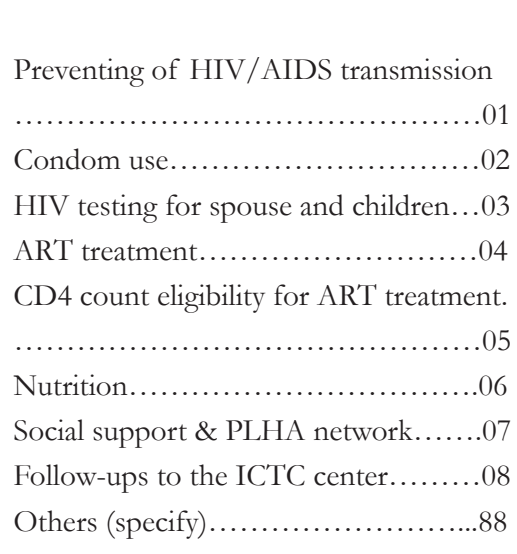 & $\begin{array}{l}\text { Yes }=01 \\
\text { No=02 } \\
{\left[-\mid \_\right]} \\
{\left[-\mid \_\right]} \\
{\left[-\mid \_\right]} \\
{\left[-\mid \_\right]} \\
{\left[-\mid \_\right]} \\
{\left[-\mid \_\right]} \\
{\left[-\mid \_\right]} \\
{\left[-\mid \_\right]} \\
{\left[-\mid \_\right]}\end{array}$ & \\
\hline 405 & $\begin{array}{l}\text { How useful were these prevention messages } \\
\text { on the printed materials? Would you say they } \\
\text { were: useful, somewhat useful or not useful? }\end{array}$ & 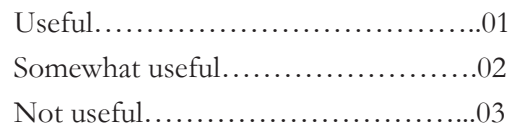 & {$\left[-\mid \_\right]$} & \\
\hline
\end{tabular}




\begin{tabular}{|c|c|c|c|c|}
\hline QID & Question & Response options/codes & $\begin{array}{l}\text { Coded } \\
\text { response }\end{array}$ & $\begin{array}{l}\text { Skip } \\
\text { pattern }\end{array}$ \\
\hline 406 & $\begin{array}{l}\text { Would you like to receive some printed } \\
\text { material? }\end{array}$ & $\begin{array}{l}Y e s \ldots \ldots \ldots \ldots \ldots \ldots \ldots \ldots \ldots \ldots \ldots \ldots \ldots \ldots \\
\text { No } \ldots \ldots \ldots \ldots \ldots \ldots \ldots \ldots \ldots \ldots \ldots \ldots \ldots \ldots \ldots \ldots\end{array}$ & [-l_] & \\
\hline \multicolumn{5}{|c|}{ Now I would like to ask few questions related to your treatment seeking behaviour } \\
\hline 407 & $\begin{array}{l}\text { Where do you go for general illnesses - } \\
\text { govt. hospital or private doctor? }\end{array}$ & 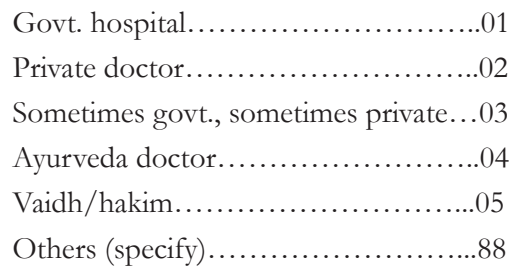 & [- & \\
\hline 408 & Why do you use this provider? & 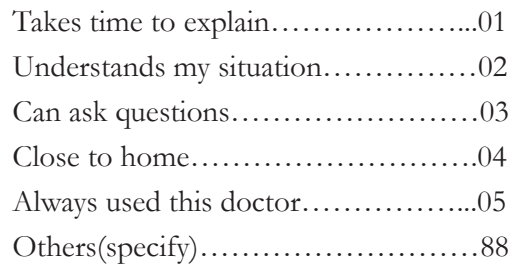 & [_l_ $]$ & \\
\hline 409 & $\begin{array}{l}\text { The last time you consulted a health } \\
\text { practitioner did you inform them of about } \\
\text { your HIV status? }\end{array}$ & 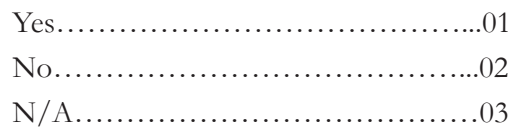 & {$\left[-\mid \_\right]$} & \\
\hline
\end{tabular}




\section{SECTION 5: SOCIAL SUPPORT AND DISCLOSURE All participants to complete this section}

\begin{tabular}{|c|c|c|c|c|}
\hline QID & Question & Response options/codes & $\begin{array}{l}\text { Coded } \\
\text { response }\end{array}$ & $\begin{array}{l}\text { Skip } \\
\text { pattern }\end{array}$ \\
\hline 501 & $\begin{array}{l}\text { Have you disclosed your HIV status to } \\
\text { anyone? }\end{array}$ & 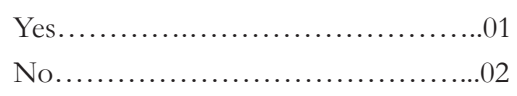 & {$[-\mid \ldots]$} & $\begin{array}{l}\text { If no skip } \\
\text { to Q503 }\end{array}$ \\
\hline 502 & $\begin{array}{l}\text { If yes, who have you disclosed your status to? } \\
\text { Instruction: } \\
\text { Do not read out the options } \\
\text { Enter } 1 \text { if mentioned, Enter } 2 \text { if not mentioned }\end{array}$ & 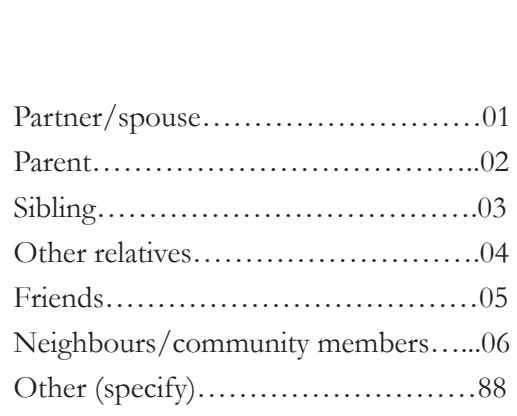 & $\begin{array}{l}\mathbf{M}=1 \\
\mathbf{N M}=2 \\
{[-\mid-]} \\
{[-\mid-]} \\
{[-\mid-]} \\
{[-\mid-]} \\
{[-\mid-]} \\
{[-\mid-]} \\
{[-\mid-]}\end{array}$ & \\
\hline 503 & Do you regret disclosing your HIV status? & 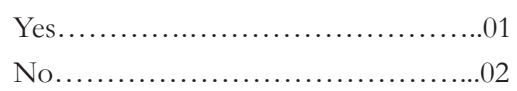 & {$[-\mid \ldots]$} & $\begin{array}{l}\text { If no skip } \\
\text { to Q505 }\end{array}$ \\
\hline 504 & $\begin{array}{l}\text { Why do you regret disclosing of your HIV } \\
\text { status? } \\
\text { Instruction: } \\
\text { Also record verbatim }\end{array}$ & 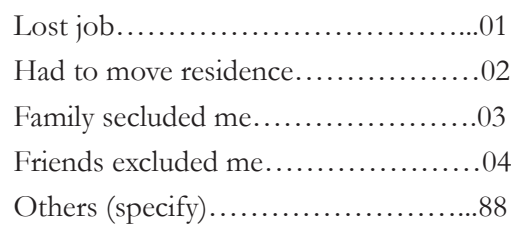 & {$[-\mid \ldots]$} & \\
\hline & Verbatim account: & & & \\
\hline 505 & $\begin{array}{l}\text { In general, how satisfied are you with the over- } \\
\text { all support (help) you get from your family? } \\
\text { Instruction: } \\
\text { If no family and staying alone, enter N/A }\end{array}$ & 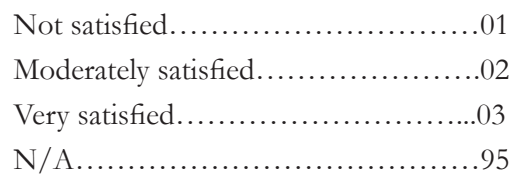 & {$\left[-\mid \_\right]$} & \\
\hline 506 & $\begin{array}{l}\text { Do you receive support from outside your } \\
\text { home or family members? }\end{array}$ & 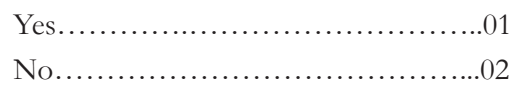 & {$\left[-\mid \_\right]$} & $\begin{array}{l}\text { If no skip } \\
\text { to Q508 }\end{array}$ \\
\hline 507 & $\begin{array}{l}\text { From where do you get support? } \\
\text { Instruction: } \\
\text { Do not read out the options } \\
\text { Enter } 1 \text { if mentioned, Enter } 2 \text { if not mentioned }\end{array}$ & 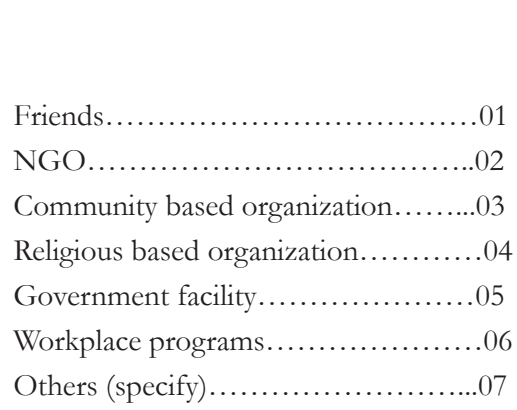 & $\begin{array}{l}\mathbf{M}=1 \\
\mathbf{N M = 2} \\
{[-\mid-]} \\
{[-\mid-]} \\
{[-\mid-]} \\
{[-\mid-]} \\
{[-\mid-]} \\
{[-\mid-]} \\
{[-\mid-]}\end{array}$ & \\
\hline
\end{tabular}




\begin{tabular}{|c|c|c|c|c|}
\hline QID & Question & Response options/codes & $\begin{array}{l}\text { Coded } \\
\text { response }\end{array}$ & $\begin{array}{l}\text { Skip } \\
\text { pattern }\end{array}$ \\
\hline 508 & Are you a member of any PLHA net work? & 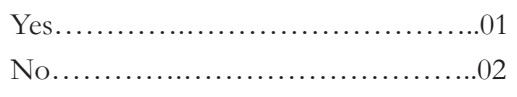 & {$\left[-\mid \_\right]$} & \\
\hline 509 & $\begin{array}{l}\text { What is your greatest worry/fear after } \\
\text { learning that you are HIV positive? } \\
\text { Instruction: } \\
\text { Do not read out the options } \\
\text { Enter } 1 \text { if mentioned, Enter } 2 \text { if not mentioned }\end{array}$ & 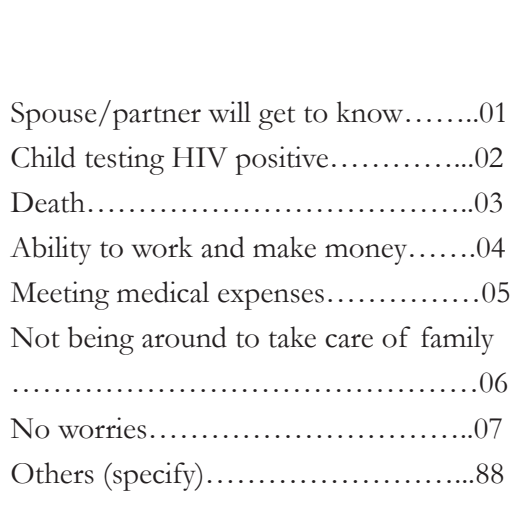 & 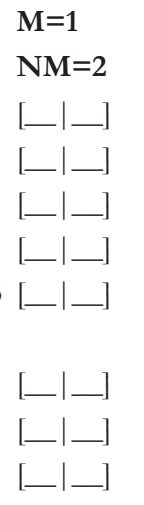 & \\
\hline 510 & $\begin{array}{l}\text { Do you know any other people in your } \\
\text { community who are HIV infected? }\end{array}$ & 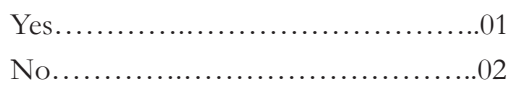 & {$\left[-\mid \_\right]$} & $\begin{array}{l}\text { If no Skip } \\
\text { to Q513 }\end{array}$ \\
\hline 511 & $\begin{array}{l}\text { How many households in your community do } \\
\text { you know where at least one family member is } \\
\text { HIV positive? } \\
\text { Instruction: } \\
\text { Enter } 00 \text { if does not know any housebold }\end{array}$ & Number.................. & {$\left[\_\mid \_\right]$} & $\begin{array}{l}\text { If } 00 \text { skip } \\
\text { to Q601 }\end{array}$ \\
\hline 512 & $\begin{array}{l}\text { Do you know if all of them are registered at } \\
\text { some ART center and taking ART treatment? }\end{array}$ & $\begin{array}{l}\text { Yes, all registered } \ldots \ldots \ldots \ldots \ldots \ldots \ldots \ldots \\
\text { No, some not registered...............02 } \\
\text { Do not know if registered or not......99 } \\
\text { N/A............................... } 95\end{array}$ & {$\left[-\mid \_\right]$} & $\begin{array}{l}\text { If } 01 \text { skip } \\
\text { to Q601 }\end{array}$ \\
\hline 513 & $\begin{array}{l}\text { What are the reasons, why PLHAs in your } \\
\text { community have not registered at ART } \\
\text { centers for treatment? } \\
\text { Instruction: } \\
\text { Do not read out the options } \\
\text { Enter } 01 \text { if mentioned, Enter } 02 \text { if not mentioned }\end{array}$ & 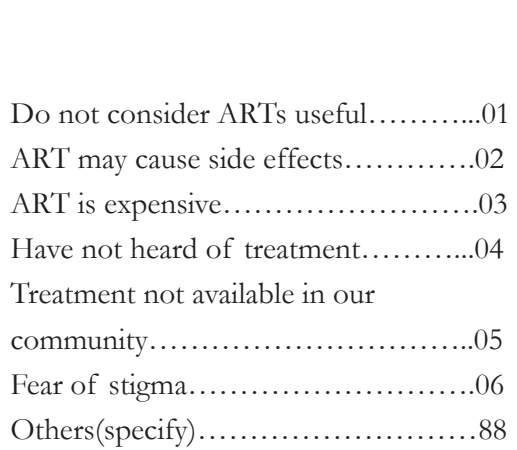 & 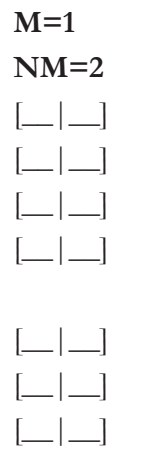 & \\
\hline
\end{tabular}




\section{SECTION VI: EXPERIENCES AT ART CENTER - STIGMA/DISCRIMINATION}

\begin{tabular}{|c|c|c|c|c|}
\hline QID & Question & Response options/codes & $\begin{array}{l}\text { Coded } \\
\text { response }\end{array}$ & $\begin{array}{l}\text { Skip } \\
\text { pattern }\end{array}$ \\
\hline 601 & $\begin{array}{l}\text { How comfortable are you discussing your } \\
\text { health concerns with clinic staff outside ART } \\
\text { center, given your HIV status? }\end{array}$ & $\begin{array}{l}\text { Not at all comfortable } \ldots \ldots \ldots \ldots \ldots \ldots 01 \\
\text { Moderately comfortable................02 } \\
\text { Completely comfortable...............03 }\end{array}$ & {$\left[-\mid \_\right]$} & \\
\hline 602 & $\begin{array}{l}\text { How satisfied are you with your access to } \\
\text { health services given your HIV status, } \\
\text { satisfied, somewhat satisfied or not satisfied? }\end{array}$ & $\begin{array}{l}\text { Satisfied } \ldots \ldots \ldots \ldots \ldots \ldots \ldots \ldots \ldots \ldots \ldots \ldots \ldots \\
\text { Somewhat satisfied } \ldots \ldots \ldots \ldots \ldots \ldots \ldots \ldots \ldots \ldots \\
\text { Not satisfied } \ldots \ldots \ldots \ldots \ldots \ldots \ldots \ldots \ldots \ldots \ldots \ldots\end{array}$ & {$\left[-\mid \_\right]$} & \\
\hline 603 & $\begin{array}{l}\text { Did you or any of your family members have } \\
\text { a negative experience with health workers/ } \\
\text { medical practitioners because of HIV status? }\end{array}$ & 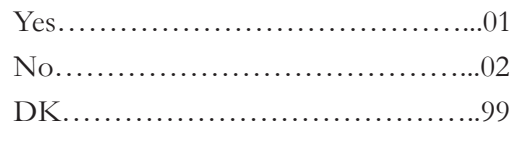 & {$[-1 \ldots]$} & $\begin{array}{l}\text { If not 'yes, } \\
\text { skip to } \\
\text { Q605 }\end{array}$ \\
\hline 604 & $\begin{array}{l}\text { If yes, what was the negative experience from } \\
\text { health workers/practitioners? }\end{array}$ & 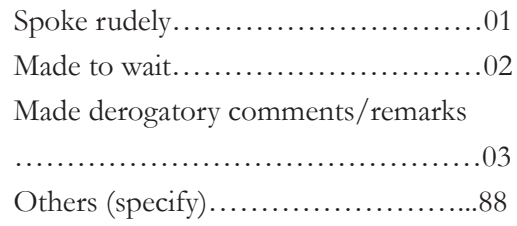 & {$[-1-]$} & \\
\hline 605 & $\begin{array}{l}\text { How accepting is your community/village of } \\
\text { HIV positive members? }\end{array}$ & $\begin{array}{l}\text { Not at all } \ldots \ldots \ldots \ldots \ldots \ldots \ldots \ldots \ldots \ldots \ldots \ldots \ldots \\
\text { Moderately } \ldots \ldots \ldots \ldots \ldots \ldots \ldots \ldots \ldots \ldots \ldots \ldots \ldots \ldots \ldots \ldots\end{array}$ & {$[-1 \ldots]$} & \\
\hline 606 & $\begin{array}{l}\text { Did you or any of your family members have } \\
\text { a negative experience in the community } \\
\text { because of your/their HIV status? }\end{array}$ & 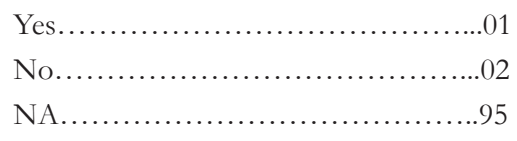 & {$\left[-\mid \_\right]$} & $\begin{array}{l}\text { If no end } \\
\text { the } \\
\text { interview }\end{array}$ \\
\hline 607 & $\begin{array}{l}\text { If yes, what did you/your family member's } \\
\text { experience? } \\
\text { Instruction: } \\
\text { Do not read out the options } \\
\text { Enter } 01 \text { if mentioned, Enter } 02 \text { if not mentioned }\end{array}$ & 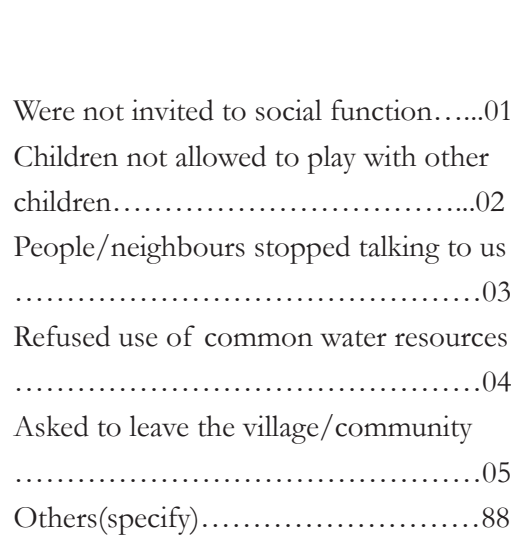 & $\begin{array}{l}\mathbf{M}=01 \\
\mathbf{N M}=02 \\
{\left[\_\mid \_\right]} \\
{\left[\_\mid \_\right]} \\
{\left[\_\mid \_\right]} \\
{\left[-\mid \_\right]} \\
{\left[-\mid \_\right]} \\
{\left[\_\mid \ldots\right]}\end{array}$ & \\
\hline
\end{tabular}

End time [----------------]

Thank you for participating 



\section{(P Population Council}

Zone 5A, Ground Floor Indian Habitat Centre Lodi Road

New Delhi 110003, India 